Water Quality of Storm Runoff and Comparison of Procedures for Estimating Storm-Runoff Loads, Volume, Event-Mean Concentrations, and the Mean Load for a Storm for Selected Properties and Constituents for Colorado Springs, Southeastern Colorado, 1992

by Paul von Guerard and William B. Weiss

U.S. GEOLOGICAL SURVEY

Water-Resources Investigations Report 94-4194

Prepared in cooperation with the

COLORADO SPRINGS CITY ENGINEERING DIVISION

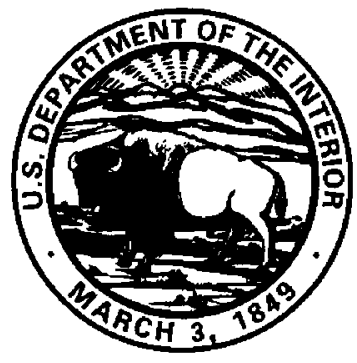




\section{U.S. DEPARTMENT OF THE INTERIOR \\ BRUCE BABBITT, Secretary}

U.S. GEOLOGICAL SURVEY

Gordon P. Eaton, Director

The use of trade, product, industry, or firm names is for descriptive purposes only and does not imply endorsement by the U.S. Govemment.

For additional information write to:

Copies of this report can be purchased from:

District Chief

U.S. Geological Survey

Box 25046, MS 415

Denver Federal Center

Denver, CO 80225
U.S. Geological Survey

Earth Science Information Center

Open-File Reports Section

Box 25286, MS 517

Denver Federal Center

Denver, CO 80225 


\section{CONTENTS}

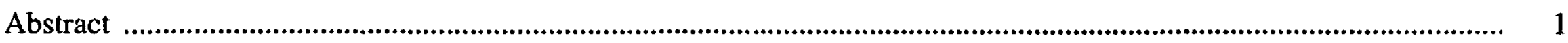

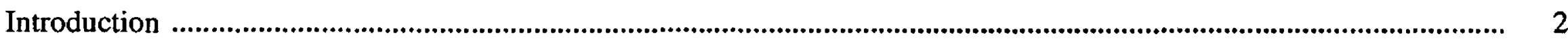

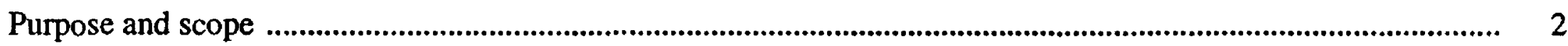

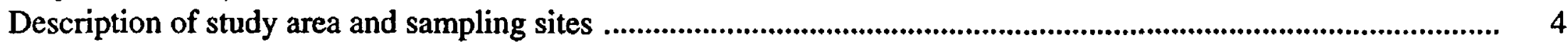

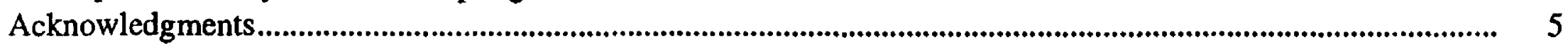

Data-collection techniques, water-quality-sampling procedures, and quality-assurance procedures ................................. 5

Precipitation and flow data-collection techniques ............................................................................................ 5

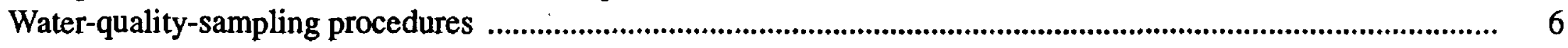

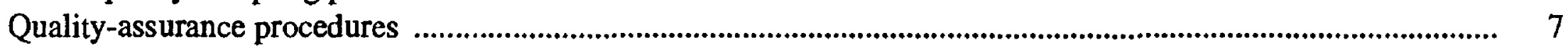

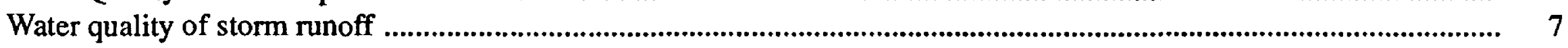

Procedures for estimating single-storm-runoff loads, volume, and event-mean concentrations ......................................... 10

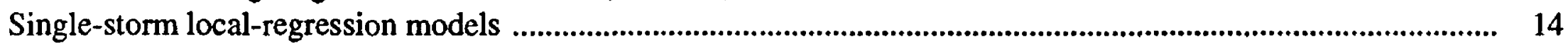

Single-storm regional-regression models ............................................................................................................... 17

Comparison of observed and estimated single-storm-runoff loads, volume, and event-mean concentrations .......... 17

Procedures for adjustment of estimates from single-storm regional-regression models using local data .................. 20

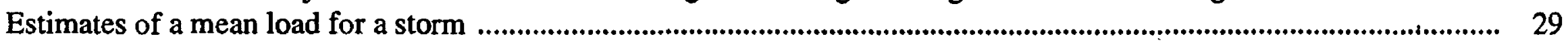

Comparison of procedures for estimating storm-runoff loads, volumes, event-mean concentrations, and

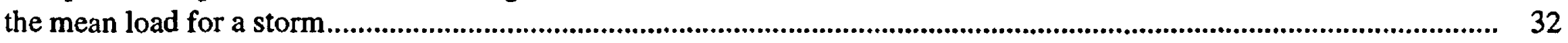

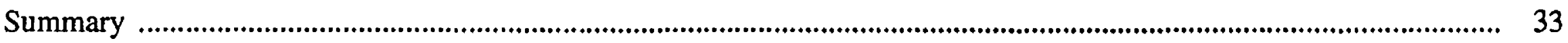

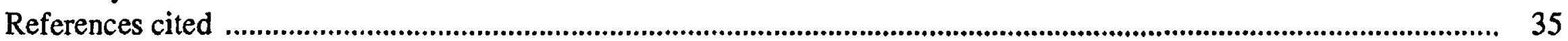

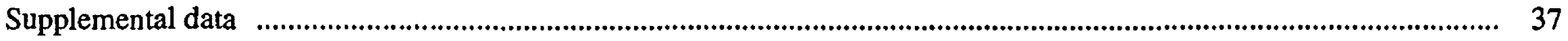

\section{FIGURES}

1. Map showing location of study area and storm-runoff-sampling sites ............................................................

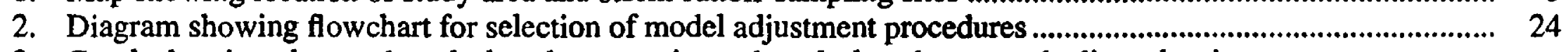

3. Graph showing observed total-phosphorus, estimated total-phosphorus, and adjusted estimates of total-phosphorus loads for storm-runoff load at site 2 .

4. Graph showing observed total ammonia plus organic nitrogen as nitrogen, estimated total ammonia plus organic nitrogen as nitrogen, and adjusted estimates of total ammonia plus organic nitrogen as nitrogen for storm-runoff event-mean concentrations at site 2 .

\section{TABLES}

1. Description of and selected land-use data for storm-runoff-sampling sites in Colorado Springs ............................. 4

2. Summary statistics for selected constituents in storm runoff-sampling sites in Colorado Springs ......................... 8

3. Summary of detections of organic compounds in storm runoff-sampling sites in Colorado Springs ..................... 11

4. Summary of single-storm local-regression models for storm-runoff loads and volume for storm runoff-sampling sites in Colorado Springs.

5. Summary of single-storm local-regression models for storm-runoff event-mean concentrations-sampling sites in Colorado Springs ...

6. Ranges of values of each explanatory variable used in single-storm local- and regional-regression models ............

7. Root-mean-square error from comparison of observed storm-runoff loads and volumes and estimated storm-runoff loads and volumes from single-storm regional-regression models

.

. Summary of residual values for observed minus estimated values of storm-runoff loads, volume, and event-mean concentrations.

Effect of model-adjustment procedures on root-mean-square error and standard error of estimate for storm-runoff loads and volume

10. Effect of model-adjustment procedures on standard error of estimate for storm-runoff

10. Effect of model-adjustment procedures on standard error of estimate for storm-runoff

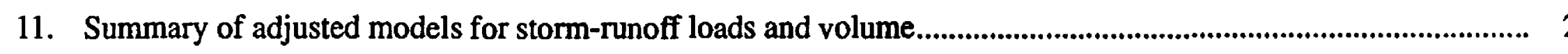


12. Summary of adjusted models for storm-runoff event-mean concentrations

13. Ranges of values of explanatory variables used in development of regression models for mean load for a storm

14. Comparison of computed mean load for a storm based on daily mean water discharge and land-use characteristics estimated mean load for a storm, and average of samples collected during rainfall runoff.

15. Summary of $\mathrm{r}^{2}$ values and standard error of estimate for regression models used to estimate mean load, in pounds, of a storm based on daily mean water discharge and land-use characteristics.

16. Precipitation and runoff characteristics for samples collected at storm-runoff sites in Colorado Springs

17. Values for instantaneous water discharge, $\mathrm{pH}$, specific conductance, water temperature, fecal coliform, fecal streptococci, residual chlorine, cyanide, oil and grease, and phenols for storm-runoff sites in Colorado Springs

18. Selected volatile-organic compounds for storm-runoff sites in Colorado Springs

19. Chemical oxygen demand, biochemical oxygen demand, specific conductance, alkalinity, dissolved solids, suspended solids, major ions, nutrients and total-recoverable metals for storm-runoff sites Colorado Springs ...... 52

20. Selected acid-base/neutral organic compounds for storm-runoff sites in Colorado Springs ................................. 57

21. Selected pesticide compounds for storm-runoff sampling sites in Colorado Springs 64

\section{CONVERSION FACTORS AND RELATED INFORMATION}

\begin{tabular}{rll}
\hline Multiply & By & To obtaln \\
\hline cubic foot $\left(\mathrm{ft}^{3}\right)$ & & \\
cubic foot per second (ft $\left.\mathrm{ft}^{3} / \mathrm{s}\right)$ & 0.028317 & cubic meter \\
foot (ft) & 0.028317 & cubic meter per second \\
gallon (gal) & 0.3048 & meter \\
inch (in.) & 3.785 & liter \\
mile (mi) & 25.4 & millimeter \\
pound (lb) & 1.609 & kilometer \\
quart (qt) & 0.454 & kilogram \\
square mile (mi $\left.{ }^{2}\right)$ & 0.9464 & liter \\
& 2.590 & square kilometer \\
\hline
\end{tabular}

Degree Fahrenheit $\left({ }^{\circ} \mathrm{F}\right)$ can be converted to degree Celsius $\left({ }^{\circ} \mathrm{C}\right)$ by using the following equation:

$$
{ }^{\circ} \mathrm{C}=5 / 9\left({ }^{\circ} \mathrm{F}-32\right) \text {. }
$$

Degree Celsius $\left({ }^{\circ} \mathrm{C}\right)$ can be converted to degree Fahrenheit $\left({ }^{\circ} \mathrm{F}\right)$ by using the following equation:

$$
{ }^{\circ} \mathrm{F}=9 / 5\left({ }^{\circ} \mathrm{C}+32\right) \text {. }
$$

The following terms and abbreviations also are used in this report:

colonies per 100 milliliters (col/100 mL)

microsiemens per centimeter at 25 degrees Celsius $(\mu \mathrm{S} / \mathrm{cm})$

milligram per liter $(\mathrm{mg} / \mathrm{L})$

microgram per liter $(\mu \mathrm{g} / \mathrm{L})$ 


\title{
Water Quality of Storm Runoff and Comparison of Procedures for Estimating Storm-Runoff Loads, Volume, Event-Mean Concentrations, and the Mean Load for a Storm for Selected Properties and Constituents for Colorado Springs, Southeastern Colorado, 1992
}

\author{
By Paul von Guerard and William B. Weiss
}

\begin{abstract}
The U.S. Environmental Protection Agency requires that municipalities that have a population of 100,000 or greater obtain National Pollutant Discharge Elimination System permits to characterize the quality of their storm runoff. In 1992, the U.S. Geological Survey, in cooperation with the Colorado Springs City Engineering Division, began a study to characterize the water quality of storm runoff and to evaluate procedures for the estimation of storm-runoff loads, volume and event-mean concentrations for selected properties and constituents.
\end{abstract}

Precipitation, streamflow, and water-quality data were collected during 1992 at five sites in Colorado Springs. Thirty-five samples were collected, seven at each of the five sites. At each site, three samples were collected for permitting purposes; two of the samples were collected during rainfall runoff, and one sample was collected during snowmelt runoff. Four additional samples were collected at each site to obtain a large enough sample size to estimate storm-runoff loads, volume, and event-mean concentrations for selected properties and constituents using linear-regression procedures developed using data from the Nationwide Urban Runoff Program (NURP). Stormwater samples were analyzed for as many as 186 properties and constituents. The constituents measured include total-recoverable metals, volatile-organic compounds, acid-base/neutral organic compounds, and pesticides.

Storm runoff sampled had large concentrations of chemical oxygen demand and 5-day biochemical oxygen demand. Chemical oxygen demand ranged from 100 to 830 milligrams per liter, and 5-day biochemical oxygen demand ranged from 14 to 260 milligrams per liter. Totalorganic carbon concentrations ranged from 18 to 240 milligrams per liter. The total-recoverable metals lead and zinc had the largest concentrations of the total-recoverable metals analyzed. Concentrations of lead ranged from 23 to 350 micrograms per liter, and concentrations of zinc ranged from 110 to 1,400 micrograms per liter.

The data for 30 storms representing rainfall runoff from 5 drainage basins were used to develop single-storm local-regression models. The response variables, storm-runoff loads, volume, and event-mean concentrations were modeled using explanatory variables for climatic, physical, and land-use characteristics. The $\mathrm{r}^{2}$ for models that use ordinary least-squares regression ranged from 0.57 to 0.86 for storm-runoff loads and volume and from 0.25 to 0.63 for storm-runoff event-mean concentrations. Except for cadmium, standard errors of estimate ranged from 43 to 115 percent for storm-runoff loads and volume and from 35 to 66 percent for storm-runoff event-mean concentrations. Eleven of the 30 concentrations collected during rainfall runoff for total-recoverable cadmium were censored (less than) concentrations. Ordinary least-squares regression should not be used with censored data; however, censored data can be included with uncensored data using tobit regression. Standard errors of estimate for storm-runoff load and event-mean concentration for total-recoverable cadmium, computed using tobit regression, are 247 and 171 percent. 
Estimates from single-storm regionalregression models, developed from the Nationwide Urban Runoff Program data base, were compared with observed storm-runoff loads, volume, and event-mean concentrations determined from samples collected in the study area. Single-storm regional-regression models tended to overestimate storm-runoff loads, volume, and event-mean concentrations. Therefore, single-storm local- and regional-regression models were combined using model-adjustment procedures to take advantage of the strengths of both models while minimizing the deficiencies of each model.

Procedures were used to develop singlestorm regression equations that were adjusted using local data and estimates from single-storm regional-regression equations. Single-storm regression models developed using model-adjustment procedures had standard errors of estimate smaller than the standard errors of estimate for the regional-regression equations. Reduction of standard error in percent ranged from $-1,980$ to -10 .

Regression models that had been developed from the Nationwide Urban Runoff Program data base for estimating the mean load for a storm were evaluated. Mean load for a storm was estimated for selected constituents. Ninety-percent confidence intervals were computed for each mean load estimate. Estimated mean load for a storm was compared to mean load of a storm that was computed based on daily mean water discharge and land-use characteristics and was compared to the mean load from six samples collected during rainfall runoff. Generally, mean load for a storm, computed based on daily mean water discharge and land-use characteristics and on mean load from samples collected during rainfall runoff, was near or within the 90-percent confidence intervals for estimates of mean load for a storm.

\section{INTRODUCTION}

Urbanization usually increases the impervious area of a watershed, which increases storm-runoff rates and, subsequently, total volume of storm runoff. Associated with storm runoff are properties and constituents that can cause the degradation of water quality locally and in receiving waters downstream. Because of concerns about the effects of urban runoff on water quality, the Water Quality Act of 1987 contains provisions that specifically address storm-runoff discharges. The U.S. Environmental Protection Agency, under section 319 of the Water Quality Act of 1987, requires that States "assess the nature and extent of nonpoint sources of pollution." Section 402(p) of the same act requires that municipalities that have a population of 100,000 or greater obtain National Pollutant Discharge Elimination System (NPDES) permits to improve the quality of storm runoff.

Final rules published by the U.S. Environmental Protection Agency (1990) require that municipalities prepare permit applications to include, among other information, the following:

1. Characterization of the quantity and quality of storm runoff for three or more major storms at selected storm-water-discharge sites that represent different combinations of commercial, industrial, and residential land uses.

2. Estimates of annual-pollutant loads and eventmean concentrations for selected constituents for the cumulative discharges of storm-runoff discharge points in the study area.

In 1992, the U.S. Geological Survey, in cooperation with the Colorado Springs City Engineering Division, began a study to characterize the water quality of storm runoff in Colorado Springs and to compare techniques for the estimation of storm-runoff loads, volume, event-mean concentrations, and mean load for a storm for selected properties and constituents.

\section{Purpose and Scope}

This report presents water-quality data collected during 1992 to characterize the water quality of storm runoff in Colorado Springs. These data were collected to help meet the requirements of the NPDES permitting process. Precipitation, streamflow, and water-quality data were collected during 1992 at five sites in Colorado Springs (fig. 1, table 1). This report presents procedures for estimating storm-runoff loads, volume, and event-mean concentrations for selected properties and constituents at unmonitored sites in Colorado Springs and to make a comparison of several procedures for estimating storm-runoff loads, volume, and eventmean concentrations. In addition, the report presents estimates of a mean load for a storm.

Thirty-five samples were collected, seven at each of the five sites. At each site, three samples were collected for NPDES permitting purposes; two of these samples were collected during rainfall runoff, and one sample was collected during snowmelt runoff. Four additional samples were collected at each site to obtain a large enough sample size to estimate storm-runoff 


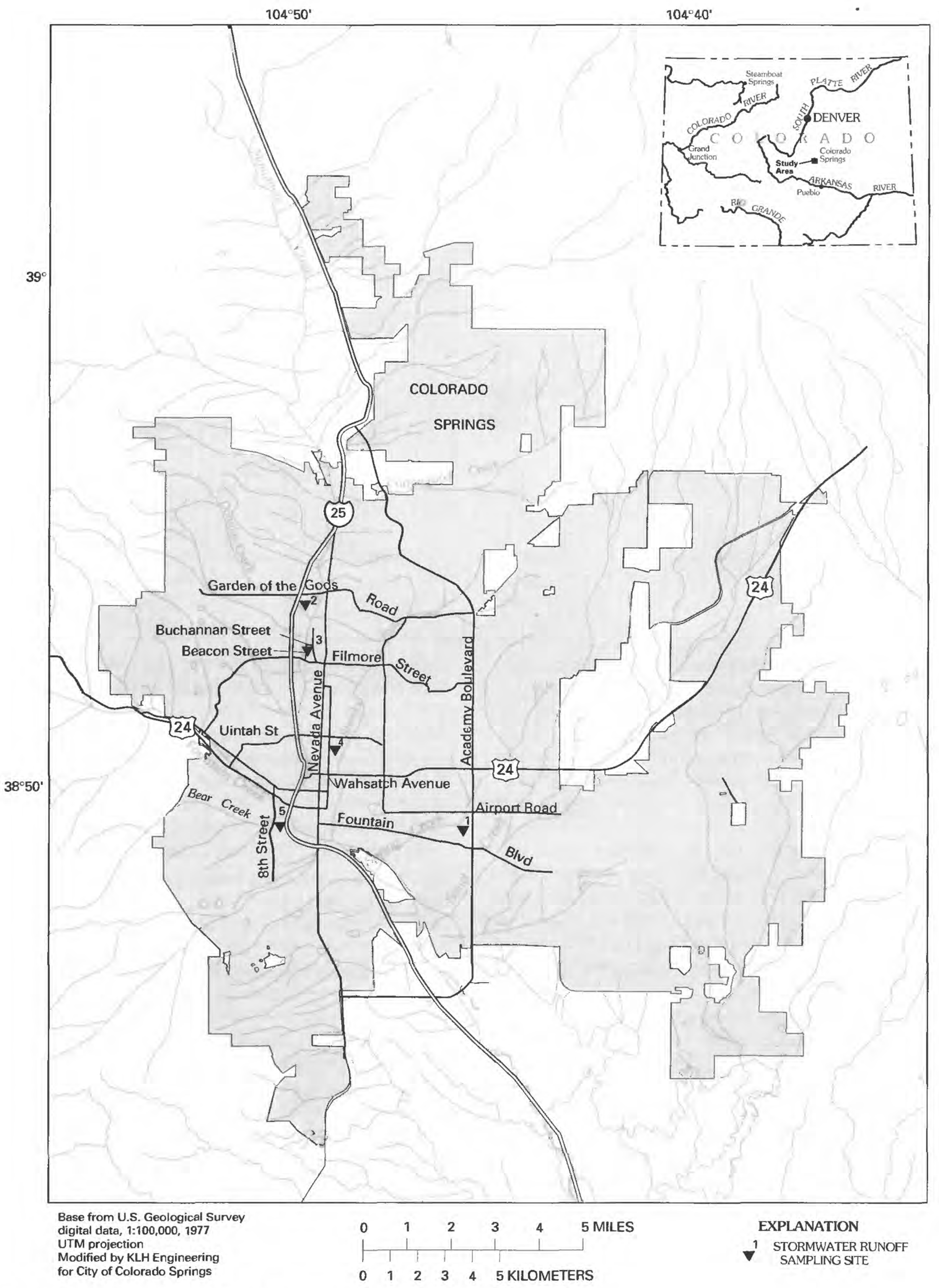

Figure 1. Location of study area and storm-runoff-sampling sites. 
Table 1. Description of and selected land-use data for storm-runoff-sampling sites in Colorado Springs

\begin{tabular}{|c|c|c|c|c|c|c|}
\hline $\begin{array}{c}\text { Site } \\
\text { number } \\
\text { (fig. 1) }\end{array}$ & Site name & $\begin{array}{l}\text { Latitude } \\
\text { and } \\
\text { longitude }\end{array}$ & $\begin{array}{c}\text { Dralnage-basin } \\
\text { area } \\
\text { (square miles) }\end{array}$ & $\begin{array}{c}\text { Impervlous } \\
\text { area } \\
\text { (percent) }\end{array}$ & Land use & $\begin{array}{l}\text { Percentage } \\
\text { of total } \\
\text { drainage } \\
\text { basin }\end{array}$ \\
\hline 3 & Beacon Street at Buchanan Street & $\begin{array}{c}38^{\circ} 52^{\prime} 40^{\prime \prime} \\
104^{\circ} 49^{\prime} 36^{\prime \prime}\end{array}$ & .173 & 55.9 & $\begin{array}{l}\text { Industrial } \\
\text { commercial } \\
\text { residential }\end{array}$ & $\begin{array}{r}79.5 \\
17.8 \\
2.7\end{array}$ \\
\hline 5 & Walmart at Eighth Street & $\begin{array}{r}38^{\circ} 49^{\prime} 35^{\prime \prime} \\
104^{\circ} 50^{\prime} 15^{\prime \prime}\end{array}$ & .049 & 40.1 & $\begin{array}{l}\text { Undeveloped } \\
\text { commercial } \\
\text { industrial } \\
\text { residential }\end{array}$ & $\begin{array}{r}43.0 \\
39.9 \\
10.3 \\
6.8\end{array}$ \\
\hline
\end{tabular}

loads, volume, and event-mean concentrations for selected properties and constituents using linearregression procedures developed using data from the Nationwide Urban Runoff Program (NURP). Stormwater samples were analyzed for as many as 186 properties and constituents (tables 16-21 in the "Supplemental Data" section at the back of this report). Some of the properties and constituents measured include $\mathrm{pH}$, specific conductance, water temperature, chemical oxygen demand, biochemical oxygen demand, bacteria, dissolved and suspended solids, major ions, nutrients, residual chlorine, total-recoverable metals, oil and grease, phenols, volatile-organic compounds, acidbase/neutral organic compounds, and pesticides.

Computed, hereinafter called observed, values for storm-runoff loads, volume, and event-mean concentrations are compared by using root-mean-square error with the results from regional-regression models developed from data collected for the NURP (Ellis and others, 1984; Driver and Tasker, 1990). Procedures are presented for using local data to adjust estimates from single-storm regional-regression models.

\section{Description of Study Area and Sampling Sites}

The study area, the city of Colorado Springs, is located in and along the eastern slope of the southern
Rocky Mountains (fig. 1). The climate of the study area is semiarid. Annual precipitation for $1948-87$ at the Colorado Springs airport ranged from 8.6 to 25.4 in. Mean annual precipitation at the airport was 15.2 in. Convective thunderstorms contribute most of the rainfall during May through September. Thunderstorms occur an average of 70 days each year (U.S. Geological Survey, 1970). Mean air temperatures are about $29^{\circ} \mathrm{F}$ in January and $70^{\circ} \mathrm{F}$ in July (Hansen and others, 1978).

Soils in the study area tend to be sandy, moderately deep to deep, and well drained to excessively well drained. The study area is underlain mainly by sandstone and shale and by alluvial and windlain deposits. The landform dominating the study area is the Colorado Piedmont. A more detailed description of the study area is discussed in von Guerard (1989). Another important aspect of the study area is the rate of growth associated with Colorado Springs. Population increased from 45,472 in 1950 to 281,140 in 1990. Additionally, total area of Colorado Springs increased from $9.4 \mathrm{mi}^{2}$ in 1950 to $181.4 \mathrm{mi}^{2}$ in 1990 (Christine Lytle, Colorado Springs City Engineering Division, written commun., 1992).

Each of the sampling sites, except for site 4, is located near the outfall of a drainage basin. Drainagebasin areas range from 0.049 to $0.327 \mathrm{mi}^{2}$, and a predominant land use can be attributed to each basin (table 1). However, all sites have a mixture of land 
uses, which is typical of Colorado Springs. For the purposes of this report, a drainage basin is defined by the local municipal storm-sewer network and is not necessarily delineated by the topography of the drainage basin. Selected descriptive data for the five drainage basins are listed in table 1. Except for site 4, all sites discharge into another part of the Colorado Springs storm-sewer system. Site 4 discharges directly into Monument Creek.

Site 1 is in southeastern Colorado Springs (fig. 1). The sampling site is in a 60-in. reinforced concrete pipe (RCP) and is accessed by a manhole. The manhole is located about $200 \mathrm{ft}$ upstream from Spring Creek along the southern boundary fence of the Valley-Hi Golf Course and is south of the sixteenth hole. The sampling site is directly upstream from an 18-in. side drain entering the RCP from the south.

Site 1 has a drainage-basin area of $0.125 \mathrm{mi}^{2}$, of which 58.1 percent is impervious area (table 1 ). Predominant land use in the drainage basin is commercial (table l) and includes retail stores and two automobile dealerships that have repair facilities.

Site 2 is in northwest Colorado Springs (fig. 1). The sampling site is in a 72-in. RCP accessed by a manhole. The manhole is located about $100 \mathrm{ft}$ southeast of the intersection of Garden of the Gods Road and Chestnut Street and is about $200 \mathrm{ft}$ upstream from Douglas Creek. Site 2 has a drainage-basin area of $0.165 \mathrm{mi}^{2}$, of which 37.5 percent is impervious area (table 1 ). Predominant land use is industrial and inchudes tool and machine forging, computer software, heating and air-conditioning manufacturing, and metallurgy companies.

Site 3 is located in north-central Colorado Springs (fig. 1). The sampling site is in a 48-in. RCP and is accessed by a manhole. The manhole is located on the northwest corner of Beacon Street at Buchanan Street and is about $400 \mathrm{ft}$ east of Monument Creek. Site 3 has a drainage-basin area of $0.173 \mathrm{mi}^{2}$, of which 55.9 percent is impervious area. Land use predominantly is industrial (table 1) and includes auto repair, machining, manufacturing, food-processing, welding, computer software, metal-fabrication, and paperdistribution companies.

Site 4 is in central Colorado Springs (fig. 1). The sampling site is in a 66-in. RCP accessed by a manhole. The manhole is about $0.7 \mathrm{mi}$ upstream from Shooks Run and $75 \mathrm{ft}$ from the southeast corner of Wahsatch Street and Cross Lane. Site 4 has a drainage-basin area of $0.327 \mathrm{mi}^{2}$, of which 34.2 percent is impervious area. Land use primarily is low-density residential (table 1) but includes some commercial businesses.
Site 5 is in southwest Colorado Springs (fig. 1). The sampling site is in a 42-in. RCP and is accessed by a manhole. The manhole is located about $30 \mathrm{ft}$ upstream from a drainage channel leading to Bear Creek and is about $300 \mathrm{ft}$ east of the southeast corner of a retail store. The sampling site is directly upstream from an 18-in. side drain entering the RCP from the northwest. Site 5 has a drainage-basin area of $0.049 \mathrm{mi}^{2}$ of which 40.1 percent is impervious area (table 1). Land use in the drainage basin predominantly is undeveloped (43 percent); however, commercial land use composes 39.9 percent of the drainage-basin area (table 1). The undeveloped area is in the upper part of the drainage basin and did not contribute runoff during the events sampled; therefore, runoff sampled is considered to be representative of commercial land use. Commercial land use includes two automobile dealerships that have repair facilities, a gas station, and several retail stores.

\section{Acknowledgments}

The authors appreciate the support and cooperation provided by Christine Lytle, Leonard Miller, and Bruce Thorson of the city of Colorado Springs. The authors thank Daniel Bunting, El Paso County Regional Floodplain Administrator, for providing precipitation duration data. The authors also thank Seth Bacon, Evan Howe, and Dennis Young, student employees of the U.S. Geological Survey, for their untiring efforts in collecting and processing stormwater samples.

\section{DATA-COLLECTION TECHNIQUES, WATER-QUALITY-SAMPLING PROCEDURES, AND QUALITY- ASSURANCE PROCEDURES}

Collection of storm-runoff data in the urban environment and for the purposes of NPDES requires specialized techniques and procedures. The following is a description of the data-collection techniques and sampling procedures used for this study.

\section{Precipitation and Flow Data-Collection Techniques}

Two to four precipitation storage gages were installed in each drainage basin. These gages were inspected at least daily from May 25 to August 16, 1992, and periodically, thereafter, until the completion 
of the snowmelt sampling. Precipitation for each drainage basin was area weighted using Thiessen polygons (Chow, 1964). In addition to providing total precipitation for each storm sampled, data collected at precipitation storage gages were used to determine precipitation conditions for 6 to 72 hours prior to the collection of a sample. To meet NPDES requirements for sampled storms, precipitation could not exceed 0.10 in. during the 72 hours preceding the collection of samples. For the four additional samples collected for selected properties and constituents, precipitation could not exceed 0.05 in. during the 6 hours preceding sample collection.

The hydraulics of flow in storm-sewer systems is extremely complex, and when coupled with the safety and logistical problems associated with accessing storm sewers, the complex hydraulics make the accurate measurement of storm-water discharge difficult. Palmer-Bowles flumes were installed at each site to measure flow in the storm sewers (Kilpatrick and others, 1985). The Palmer-Bowles flume causes flow in the RCP to be subcritical at the flume approach and forces flow through critical depth in the flume throat. Kilpatrick and others (1985) developed calibration curves for the Palmer-Bowles flumes. These calibration curves are within \pm 10 percent of measured flow. Depth of flow in the RCP was measured using a gaspurge conoflow pressure-regulating system and a pressure transducer. Flow depth was recorded using dataloggers.

\section{Water-Quality-Sampling Procedures}

Thirty samples were collected during rainfall runoff, and five samples were collected during snowmelt runoff. Prior to sample collection, all samplecollection bottles were washed using a nonphosphate detergent and were rinsed using tap water, 1-percent hydrochloric acid solution, and pesticide-grade methanol. Initially, and after each storm was sampled, pumping-sampler-intake lines were cleaned, using the procedure just described; in addition, the lines were given a final rinse of organic-free water. Glass mason jars used for the collection of samples for bacteria analysis were sterilized using an autoclave.

Storm-runoff samples were obtained by manually collecting grab samples and by using automaticpumping samplers. Grab samples were collected for $\mathrm{pH}$, bacteria, residual chlorine, total-recoverable cyanide, oil and grease, phenols, and volatile-organic compounds. Water temperature was measured from a grab sample immediately after collection. Grab samples were collected as depth-integrated point sam- ples and were collected using Teflon USDH-81 samplers (Federal Inter-Agency Sedimentation Project, written commun., 1992) that were equipped with 1-qt glass jars. At all sites and at all flow depths, flow in the RCP was turbulent and well mixed.

Composite samples were collected for chemical oxygen demand, biochemical oxygen demand, specific conductance, alkalinity, dissolved and suspended solids, major ions, nutrients, total-recoverable metals, acid-base/neutral organic compounds, and pesticides. Composite samples were first collected discretely using automatic-pumping samplers equipped with Teflon intake lines and four 1-gal glass bottles. The samplers were activated by the datalogger when a predetermined flow in the RCP was exceeded. After the sampler was activated, samples were collected at intervals of 5 to 30 minutes, depending on the flow in the RCP. Samples were collected until the water level in the RCP dropped below the sampler orifice. After the bottles were filled, they were capped with Teflon-lined lids, put on ice, and transported to a field laboratory for flow-weight compositing. Flow-weighted aliquots were split from the sample into a stainless-steel Teflonlined churn, using a Teflon cone-splitter that was equipped with Teflon tubing. The aliquot needed from each discrete sample used for flow weighting was determined using an arithmetic weighting formula:

$$
\mathrm{SV}=(\mathrm{QSAMP} * \mathrm{TVSR}) / \mathrm{TQSC}
$$

where

$$
\begin{aligned}
\text { Sv = } & \text { the aliquot from a particular discrete } \\
& \text { sample; } \\
\text { QSAMP = } & \text { instantaneous flow when the particular } \\
& \text { discrete sample was collected; } \\
\text { TVSR = } & \text { the total volume of flow-weighted } \\
& \text { sample needed for processing; and } \\
\text { TQSC = } & \text { is the sum of instantaneous flows for } \\
& \text { all discrete samples from which ali- } \\
& \text { quots will be drawn. }
\end{aligned}
$$

After compositing, samples were shipped to the U.S. Geological Survey National Water-Quality Laboratory in Arvada, Colorado, for analysis.

The concentration of the flow-weighted composite sample is used to represent the storm-runoff event-mean concentration. Storm-runoff load, in pounds, was computed by multiplying the event-mean concentration by the volume of storm runoff for the storm sampled and by a unit conversion constant. 


\section{Quality-Assurance Procedures}

Trip blanks and field-equipment blanks were collected and analyzed for all properties and constituents to evaluate potential field contamination. Trip blanks are sample bottles filled with water devoid of any organic or inorganic constituents. Field and laboratory spikes were used to evaluate recovery and potential loss of concentration of organic compounds. Field and laboratory spikes are sample water spiked with a constituent of a known concentration.

Trip blanks were collected to evaluate any possible contamination occurring during transport of the sample from the field to the analytical laboratory. Values and concentrations in trip blanks were almost equal to or less than the analytical detection limit for all properties and constituents. Values and concentrations in field-equipment blanks were almost equal to or less than the analytical detection limits for every property and constituent except for chemical oxygen demand and total-organic carbon indicating there was little or no field contamination.

Field and laboratory spikes for organic compounds were done to evaluate potential analytical recoveries and possible degradation of constituents from the time of collection to when samples were analyzed. Average percent recoveries for volatile organic compounds were 43 percent for field spikes and 67 percent for lab spikes. The percent recoveries of less than 100 percent for the spikes indicate some loss of constituent concentration between sample collection and analysis. Average percent recoveries for acid-base/neutral organic compounds were 80 percent for field spikes and 97 percent for laboratory spikes. For pesticide compounds, average percent recoveries were 80 percent for field spikes and 82 percent for laboratory spikes. Generally, recovery of constituents was less than 100 percent, especially for volatile organic compounds. However, percent recovery was greater than 100 percent for certain constituents. This large percent recovery can be accounted for by the possible matrix effects on certain spiked concentrations and by the precision of the analytical technique used in the analysis (Mary Olsen, U.S. Geological Survey, oral commun., 1993).

\section{WATER QUALITY OF STORM RUNOFF}

Storm-runoff water-quality data were collected at sites that represent commercial (sites 1 and 5), industrial (sites 2 and 3), and residential (site 4) land uses (table 1). The water-quality properties and constituents collected can be separated into the following major categories:
1. Properties-pH, specific conductance, temperature, chemical oxygen demand, and biochemical oxygen demand,

2. Bacteria-fecal coliform and fecal streptococci,

3. Dissolved and suspended solids and major ions,

4. Nutrients-nitrogen and phosphorus,

5. Total-recoverable metals,

6. Total-organic carbon,

7. Organic compounds-volatile, acid-base/neutral, and pesticides.

Three samples were collected at each site for NPDES permitting purposes. Four additional samples were collected for selected constituents that also were collected for NPDES purposes. The additional four samples were collected to provide a large enough sample size (seven samples per site) to estimate stormrunoff loads and event-mean concentrations for selected constituents using linear-regression procedures developed using data from the NURP. These data are summarized in table 2.

Median concentrations of chemical and 5-day biochemical oxygen demand were highest for site 4 (table 2); the median concentration for chemical oxygen demand for site 4 was $330 \mathrm{mg} / \mathrm{L}$ and for 5-day biochemical oxygen demand was $86 \mathrm{mg} / \mathrm{L}$. Storm runoff generally had a neutral $\mathrm{pH}$. The median value of $\mathrm{pH}$ for commercial sites was 7.5, for industrial sites was 7.3, and for the residential site was 7.4. Specific conductance of storm runoff was largest for samples collected during snowmelt runoff. Median specific conductance for all samples collected during snowmelt runoff was $385 \mu \mathrm{S} / \mathrm{cm}$; during rainfall runoff, the median specific conductance was $104 \mu \mathrm{S} / \mathrm{cm}$. Water temperatures ranged from 0.0 (during snowmelt runoff) to $24.5^{\circ} \mathrm{C}$ (table 17 ).

The maximum counts of fecal coliform and fecal streptococci were measured at sites 1 and 4 (table 17). Median counts for all samples at sites 1 and 4 were 4,900 and 17,000 col/100 mL. However, largest median counts for bacteria were in samples from site 4 at $4,900 \mathrm{col} / 100 \mathrm{~mL}$ for fecal coliform and $20,500 \mathrm{col} / 100 \mathrm{~mL}$ for fecal streptococci.

Dissolved-solids concentrations ranged from 34 to $4,240 \mathrm{mg} / \mathrm{L}$ (table 19) for all land uses, and the range of concentrations was similar for all sites. The largest concentrations of dissolved solids were measured from snowmelt samples. The largest concentration of suspended solids, $1,400 \mathrm{mg} / \mathrm{L}$, was measured for site 5 (table 19). The largest median concentration of suspended solids was $826 \mathrm{mg} / \mathrm{L}$ at site 5 . 


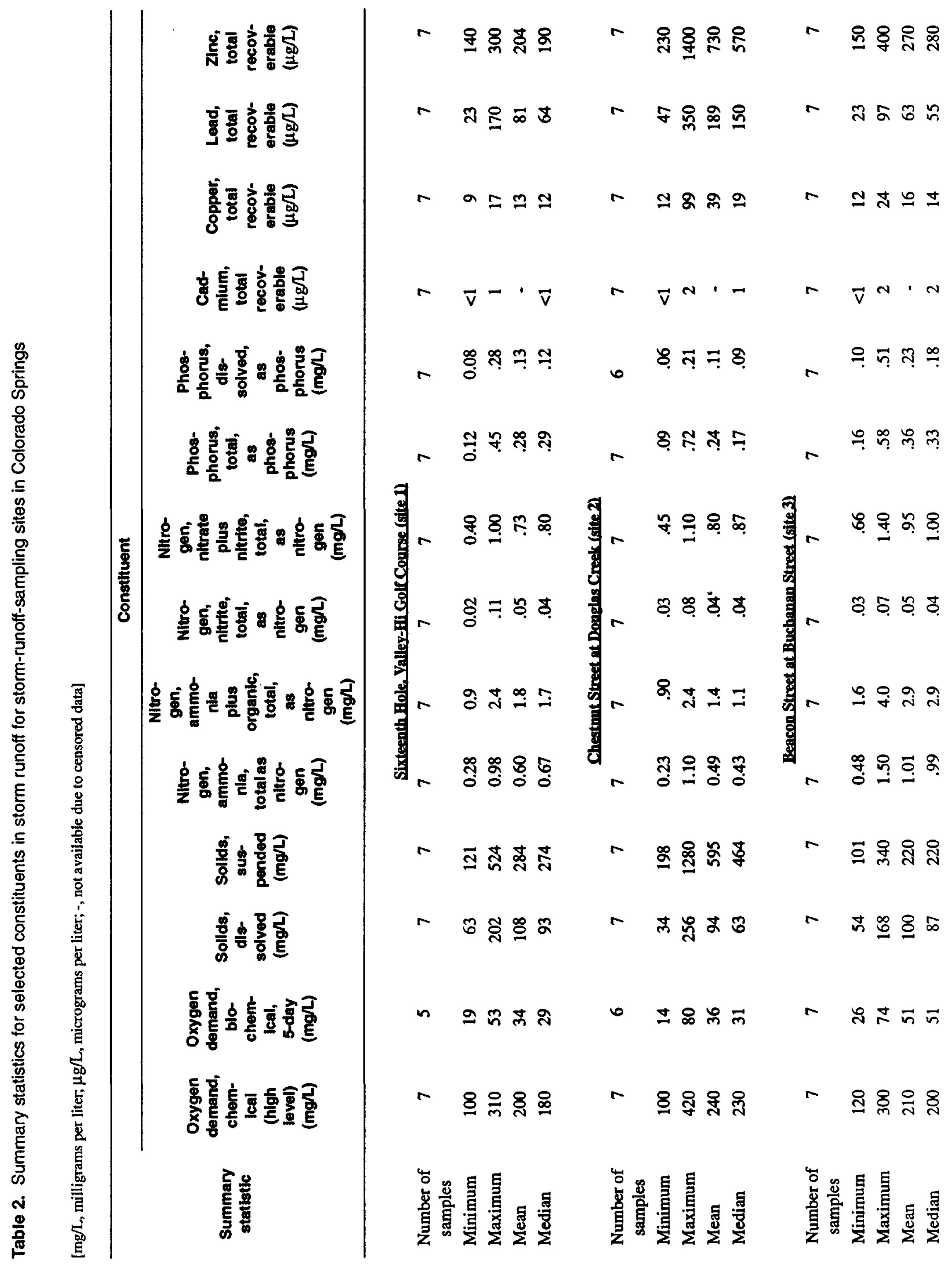




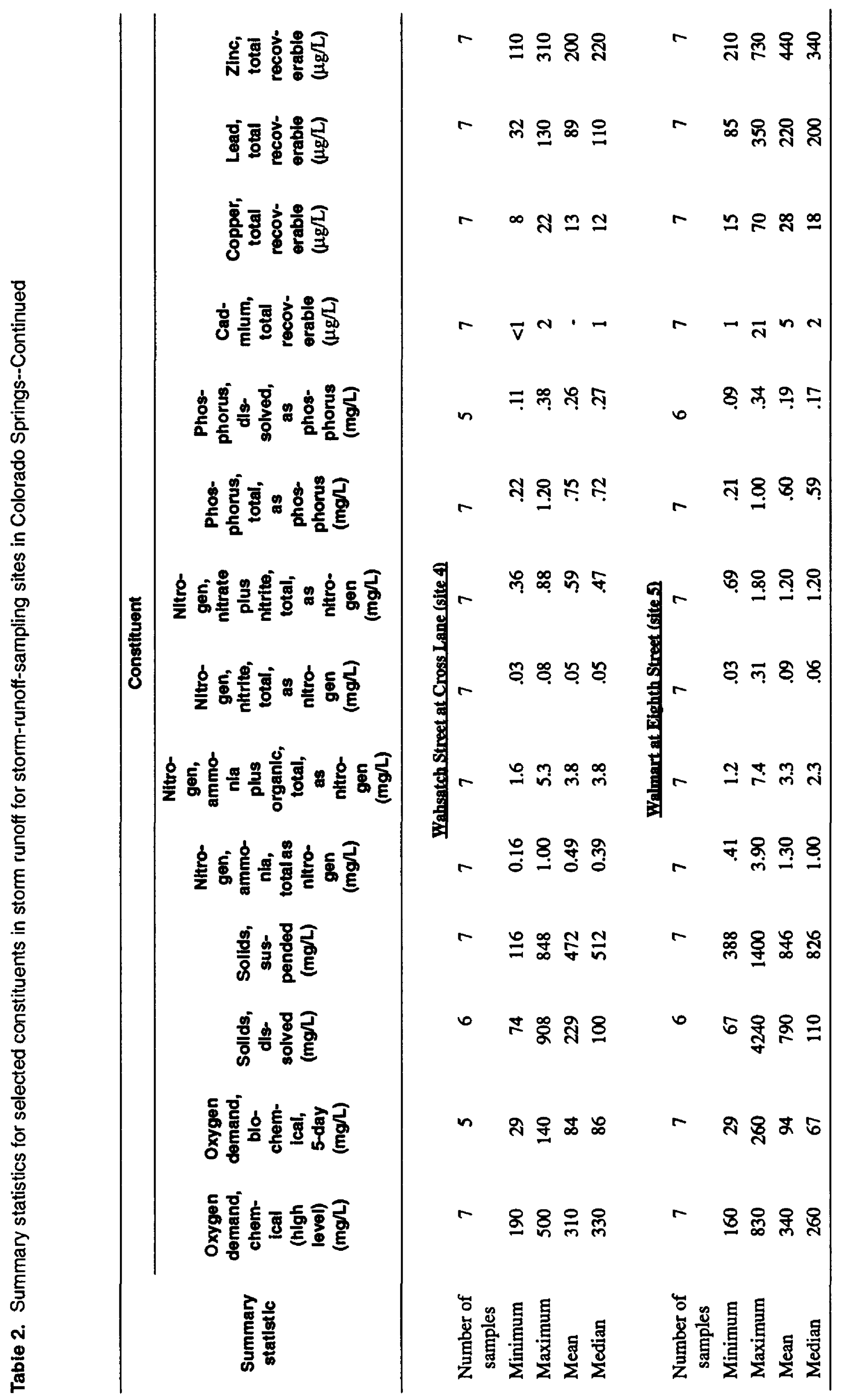


Samples were collected to characterize concentrations of nutrients (nitrogen and phosphorous) in storm runoff. Sites 3 and 5 had the largest median concentrations for ammonia as nitrogen and nitrate plus nitrite as nitrogen, 1.0 and $1.2 \mathrm{mg} / \mathrm{L}$. Site 4 had the largest median concentrations for total ammonia plus organic nitrogen as nitrogen, and total and dissolved phosphorus at $3.8,0.72$, and $0.27 \mathrm{mg} / \mathrm{L}$.

Generally, concentrations of total-recoverable metals were similar for all sites (table 19). Concentrations of total-recoverable lead were largest for sites 2 and 5 and had a median concentration of $180 \mu \mathrm{g} / \mathrm{L}$.

Concentrations of total-recoverable copper, nickel, and zinc were largest for sites 2 and 5 and had median concentrations of 18.0, 16.0, and $500 \mu \mathrm{g} / \mathrm{L}$.

The largest median concentration of totalorganic carbon was $100 \mathrm{mg} / \mathrm{L}$ at site 4 . The median concentration of total-organic carbon for sites $1,2,3$, and 5 was $52 \mathrm{mg} / \mathrm{L}$.

Each sample collected for volatile-organic compounds (VOC) was analyzed for 61 constituents. The largest number of VOC's detected were 21 at site 4 and 31 at site 5. The number of VOC's detected, the number of samples collected, and the number of times each VOC was detected are listed for each site in table 3. Generally, volatile organic compounds were detected more often in samples collected during snowmelt runoff than in samples collected during rainfall runoff. A possible explanation for the higher number of detections of volatile organic compounds in snowmeltrunoff samples is that these samples were collected at a lower temperature than were the samples collected during rainfall runoff. Volatile organic compcunds volatilize at a slower rate at the lower temperatures during snowmelt runoff. The volatile organic compounds detected generally were associated with gasoline and other petroleum products.

Each sample collected for acid-base/neutral organic compounds was analyzed for 57 constituents. The largest number of acid-base/neutral organic compounds detected was 21 at sites 1 and 3 and 26 at site 2 . The number of acid-base/neutral compounds detected, the number of samples collected, and the number of times each compound was detected is listed in table 3. Except for chlordane in the sample collected at site 4 on June 12, concentrations of pesticides were less than the analytical detection limits for all samples.

\section{PROCEDURES FOR ESTIMATING SINGLE-STORM-RUNOFF LOADS, VOLUME, AND EVENT-MEAN CONCENTRATIONS}

The NPDES permitting process requires the estimation of total annual pollutant loads and event-mean concentrations for 12 properties and constituents. The
12 properties and constituents are chemical oxygen demand (COD), 5-day biochemical oxygen demand (BOD), dissolved solids (DS), suspended solids (SS), total nitrogen (TN), total ammonia plus organic nitrogen as nitrogen (TKN), total phosphorus (TP), dissolved phosphorus (DP), total-recoverable cadmium (CD), total-recoverable copper (CU), total-recoverable lead (PB), and total-recoverable zinc (ZN). In a simplistic assessment, seasonal or annual storm-runoff loads, volume, and event-mean concentrations could be estimated using mean concentrations of properties and constituents from the set of sampled storms. However, better estimates of single-storm-runoff loads and eventmean concentrations can result by using multiple-

regression analysis to relate these response variables to climatic, physical, and land-use characteristics (Driver and Tasker, 1990). These regression models could be used with precipitation data and physical and land-use information to estimate single-storm-runoff loads, volume, and event-mean concentrations for individual storms at ungaged storm-runoff sites.

The form of the regression equation used for estimating single-storm-runoff loads, volume, and eventmean concentrations is a linear function of the logarithmic-transformed variables:

$$
\frac{\log Y=\log B_{0}+B_{1} \log X_{1}+B_{2} \log X_{2}+\ldots .}{+B_{N} \log X_{N}}
$$

Taking the antilogs, the equation becomes:

$$
\mathrm{Y}=\mathrm{B}_{0} \mathrm{X}_{1}^{\mathrm{B} 1} \mathrm{X}_{2}^{\mathrm{B} 2} \ldots . . \mathrm{X}_{\mathrm{N}}^{\mathrm{BN}}
$$

where$$
\mathrm{Y}=\text { estimated storm-runoff load, }
$$
volume, or event-mean concentration (response variable);

$\mathrm{B}_{0}, \mathrm{~B}_{1}, \mathrm{~B}_{2}, \mathrm{~B}_{\mathrm{N}}=$ regression coefficients; $\mathrm{X}_{1}, \mathrm{X}_{2}, \ldots, \mathrm{X}_{\mathrm{N}}=$ climatic, physical, or land-use variables (explanatory variables); and

$\mathbf{N}$ = number of climatic, physical, and land-use variables in the regression model.

A transformation bias is produced when logarithms of the estimated mean response (log of the response variable) is retransformed (equation 3). This transformation bias usually results in the underestimation of the estimated mean response. However, the major part of this transformation bias may be eliminated by multiplying the estimated mean response by a correction factor (Duan, 1983):

$$
\mathrm{BCF}=\frac{1}{\mathrm{n}} \sum_{i=1}^{\mathrm{n}} 10^{\mathrm{e}_{i}}
$$


Table 3. Summary of detections of organic compounds in storm runoff for storm-runoff-sampling sites in Colorado Springs

[All compounds in micrograms per liter]

\begin{tabular}{ccc}
\hline Site & Constituent & $\begin{array}{c}\text { Number } \\
\text { of } \\
\text { of } \\
\text { detections }\end{array}$ \\
\hline
\end{tabular}

Sixteenth Hole, Valley-Hi Golf Course (site 1)

VOLATILE-ORGANIC COMPOUNDS

Benzene, total 10

Ethyl-benzene, total 10

Naphthalene, total $\quad 10$

Toluene, total $\quad 10$

Xylene, water, whole, total recoverable

1,2,4-trimethyl benzene, water, whole, recoverable $10 \quad 2$

1,3,5-trimethyl benzene, water, whole, recoverable $10 \quad 1$

ACID-BASE/NEUTRAL ORGANIC COMPOUNDS

Benzogh-i-perylenel, 12-benzo perylene, total 3

Benzo-b-flouranthene, total $\quad 3 \quad 2$

Bis (2-ethylhexyl) phthalate, total $\quad 3 \quad 3$

Chrysene, total

Di-n-butyl phthalat, total

Fluoranthene, total

Indeno (1,2,3-cd) pyrene, total

Phenanthrene, total

Pyrene, total

1

1

3

2

3

2

(n)

total

\section{VOLATILE-ORGANIC COMPOUNDS}

Chestnut Street at Douglas Creek (site 2)

Naphthalene, total

Toluene, total

Xylene, water, whole, total recoverable

1,2,4-trimethyl benzene, water, whole, recoverable

32

$3 \quad 3$

$3 \quad 3$

31

33

3

\section{ACID-BASE/NEUTRAL ORGANIC COMPOUNDS}

Anthracene, total

Benzo-a-anthracenel, 2-benzanthracene, total

Benzo-a-pyrene, total

Benzogh-i-perylenel, 12-benzo perylene, total

Benzo-b-fluoranthene, total

Benzo-k-fluoranthene, total

Bis (2-ethylhexyl) phthalate, total

Chrysene, total

Fluoranthene, total

Indeno $(1,2,3-c d)$ pyrene, total

Phenanthrene, total

Pyrene, total

$\begin{array}{ll}3 & 2 \\ 3 & 2 \\ 3 & 2 \\ 3 & 1 \\ 3 & 2 \\ 3 & 2 \\ 3 & 3 \\ 3 & 2 \\ 3 & 3 \\ 3 & 2 \\ 3 & 2 \\ 3 & 3\end{array}$


Table 3. Summary of detections of organic compounds in storm runoff for storm-runoff-sampling sites in Colorado Springs --Continued

\begin{tabular}{llcc}
\hline Site & Constituent & $\begin{array}{c}\text { Number } \\
\text { of } \\
\text { of } \\
\text { samples }\end{array}$ & detections \\
\hline
\end{tabular}

Beacon Street at Buchanan Street (site 3)

Wahsatch Street at Cross Lane (site 4)

\section{VOLATILE-ORGANIC COMPOUNDS}

Dichlorobromomethane, total $\quad 8 \quad 1$

Naphthalene, total $\quad 8$

Toluene, total $\quad 8$

Xylene, water, whole, total recoverable $\quad 8 \quad 2$

1,2,4-trimethyl benzene, water, whole, recoverable $\quad 8 \quad 1$

1,3,5-trimethyl benzene, water, whole, recoverable $\quad 8 \quad 1$

\section{ACID-BASENEUTRAL COMPOUNDS}

Anthracene, total

Benzo-a-anthracenel, 2-benzanthracene, total

Benzo-a-pyrene, total

Benzogh-i-perylenel, 12-benzo perylene, total

Benzo-b-flouranthene, total

Benzo-k-fluoranthene, total

Bis (2-ethylhexyl) phthalate, total

Chrysene, total

Fluoranthene, total

Indeno (1,2,3-cd) pyrene, total

Phenanthrene, total

Pyrene, total

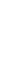
6

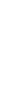


Table 3. Summary of detections of organic compounds in storm runoff for storm-runoff-sampling sites in Colorado Springs

\begin{tabular}{|c|c|c|c|}
\hline Site & Constttuent & $\begin{array}{c}\text { Number } \\
\text { of } \\
\text { samples }\end{array}$ & $\begin{array}{c}\text { Number } \\
\text { of } \\
\text { detectlons }\end{array}$ \\
\hline \multicolumn{4}{|c|}{ PESTICIDE COMPOUNDS } \\
\hline \multirow{2}{*}{$\begin{array}{l}\text { Wahsatch Street at Cross Lane (site 4) } \\
\text {--Continued }\end{array}$} & Chlordane, total & 3 & 1 \\
\hline & VOLATILE-ORGANIC COMPOUNDS & & \\
\hline \multirow[t]{21}{*}{ Walmart at Eighth Street (site 5) } & Benzene, total & 9 & 1 \\
\hline & Chloroform, total & 9 & 5 \\
\hline & Cis-1,2-dichloroethene, water, total & 9 & 1 \\
\hline & Ethyl benzene, total & 9 & 1 \\
\hline & N-butyl benzene, water, whole, recoverable & 9 & 1 \\
\hline & N-propyl benzene, water, whole, recoverable & 9 & 1 \\
\hline & Naphthalene, total & 9 & 6 \\
\hline & Toluene, total & 9 & 5 \\
\hline & Xylene, water, whole, total recoverable & 9 & 4 \\
\hline & 1,1,1-trichloroethane, total & 9 & 2 \\
\hline & 1,2,4-trimethyl benzene, water, whole, recoverable & 9 & 3 \\
\hline & 1,3,5-trimethyl benzene, water, whole, recoverable & 9 & 1 \\
\hline & ACID-BASE/NEUTRAL ORGANIC COMPOUNDS & & \\
\hline & Anthracene, total & 3 & 1 \\
\hline & Bis (2-ethylhexyl) phthalate, total & 3 & 3 \\
\hline & Di-n-octyl phthalate, total & 3 & 1 \\
\hline & Di-n-butyl phthalate, total & 3 & 2 \\
\hline & Fluoranthene, total & 3 & 3 \\
\hline & N-butyl benzyl phthalate, total & 3 & 2 \\
\hline & Phenanthrene, total & 3 & 2 \\
\hline & Pyrene, total & 3 & 3 \\
\hline
\end{tabular}


where

$$
\begin{aligned}
\mathrm{BCF}= & \text { the bias correction factor, } \\
\mathrm{n}= & \text { the number of observations in the data set, } \\
& \text { and } \\
\mathrm{e}_{i}= & \text { least-squares residual for observation i from } \\
& \text { the calibration data set, in log units. }
\end{aligned}
$$

\section{Single-Storm Local-Regression Models}

Using data collected for 30 rainfall-runoff storms, single-storm local-regression models were developed for the Colorado Springs area for estimating storm-runoff loads for the 12 NPDES properties and constituents and for estimating storm-runoff volume and event-mean concentrations for the 12 NPDES properties and constituents. The data for 30 storms from 5 drainage basins ( 6 storms in each drainage basin) are listed in tables 16 and 19. Data collected for snowmelt samples (the November and December samples) were not available at the time of this analysis and, thus, were not included in the development of the local-regression models. Also, techniques for estimating storm-runoff loads, volumes, and event-mean concentrations were developed using data for rainfallrunoff conditions (Ellis and others, 1984; Driver and Tasker, 1990), and the snowmelt samples represent different hydrologic processes and need to be considered separately. The models were developed using ordinary least-squares regression, except for total-recoverable cadmium (CD). The CD data set had 11 of the 30 analyses reported as less than (censored) values. Ordinary least-squares regression should not be used with censored data. However, censored data can be included with uncensored data using tobit regression, which is similar to least-squares regression, in which the parameter estimates are fit using maximum-likelihood estimation (Helsel and Hirsch, 1992). Except for two, all CD concentrations were $3 \mu \mathrm{g} / \mathrm{L}$ or less (table 19 ); however, the $\mathrm{CD}$ concentration of $21 \mu \mathrm{g} / \mathrm{L}$ was not included in this analysis because it is not considered representative of storm runoff in the study area. Stormrunoff loads, volume, and event-mean concentrations (response variables) were modeled using the following climatic, physical, and land-use characteristics (explanatory variables):

1. Total rainfall (TRN), in inches,

2. Total contributing drainage-basin area (DA), in

3. Impervious area (IA), as a percent of total contributing drainage-basin area,
4. Industrial land use (LUI), as a percent of total contributing drainage-basin area,

5. Commercial land use (LUC), as a percent of total contributing drainage-basin area,

6. Residential land use (LUR), as a percent of total contributing drainage-basin area,

7. Nonurban land use (LUN), as a percent of total contributing drainage-basin area,

8. Period (in days) preceding collection of a sample having less than $0.10 \mathrm{in}$. of precipitation (DD).

The RSQUARE procedure (Statistical Analysis System Institute, Inc., 1990) was used to determine which combination of explanatory variables composed the most suitable regression model. The RSQUARE procedure performs all possible linear regressions for all possible combinations of explanatory variables and determines the subsets of explanatory variables that have the largest $\mathbf{r}^{2}$ value (Statistical Analysis System Institute, Inc., 1990). For the models to have a hydrologic and physiographic basis, only subset regression models including the explanatory variables TRN and DA were evaluated. The most suitable regression model was selected on the basis of the statistical significance of explanatory variables in the regression, the values of $\mathbf{r}^{2}$, and checked using other model selection criteria (Statistical Analysis System Institute, Inc.,

1990). An $r^{2}$ value is the proportion of the total variation of the response variable that is explained by the explanatory variables. For certain properties and constituents, all of the possible regressions included explanatory variables that were not significant at the 5-percent confidence level. Therefore, some regression models that were selected as the most suitable included explanatory variables that were not significant at the 5-percent confidence level (tables 4 and 5). However, inclusion of these variables in the models improved the computed $\mathrm{r}^{2}$ and were considered useful predictors of the dependent variables. For event-mean concentrations for BOD, the local-regression model was not significant at the 5-percent confidence level (table 5). For evaluating all possible regression models (RSQUARE procedure) for storm-runoff loads and for event-mean concentrations for $\mathrm{CD}$, only uncensored data were used (19 of the 30 values for $C D$ were uncensored).

Plots of residual (observed values minus estimated values) compared to estimated values were analyzed to evaluate the constant variance (homoscedasticity) of the residuals. Residual plots for all of the most suitable models indicate that the variance of the residuals generally is constant throughout the entire 


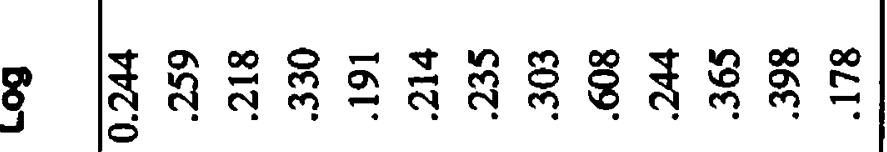
r $\quad \frac{0}{0} \stackrel{0}{\circ}$ 웅

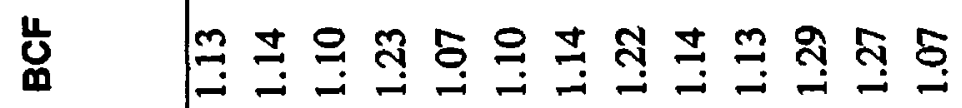

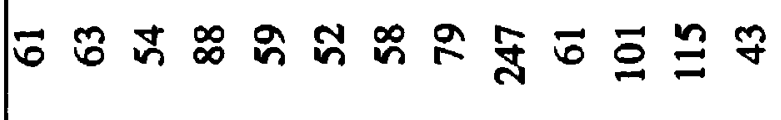
용

$\frac{\bar{n}}{\frac{\pi}{2}}$

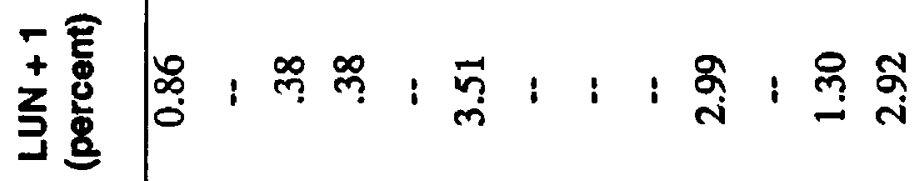

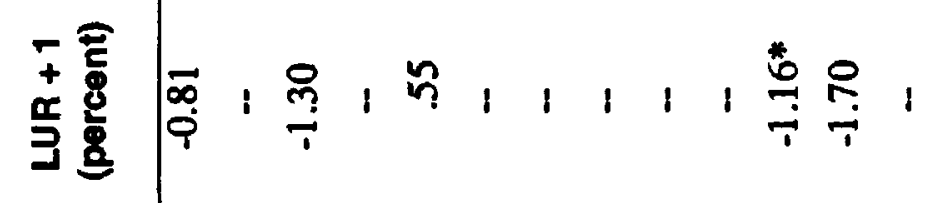

竞

总

专弯

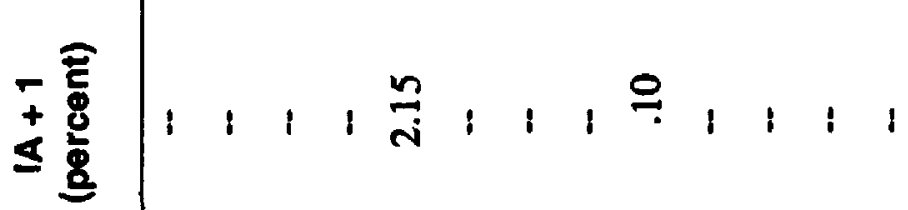

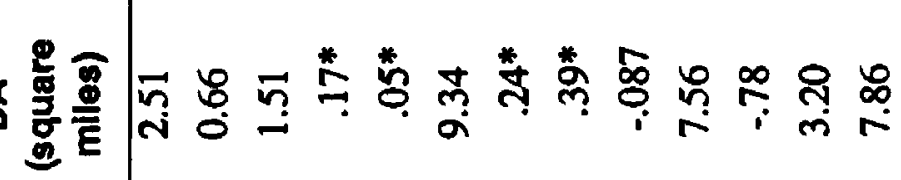

Z芒离

造

声

$\infty^{N}$

空

$+$

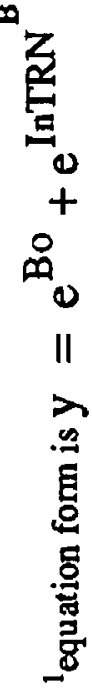

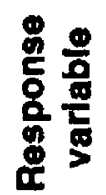

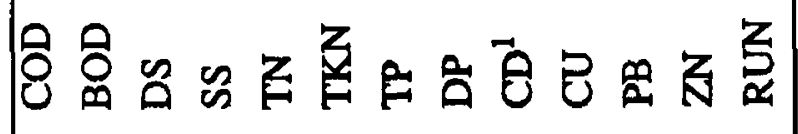




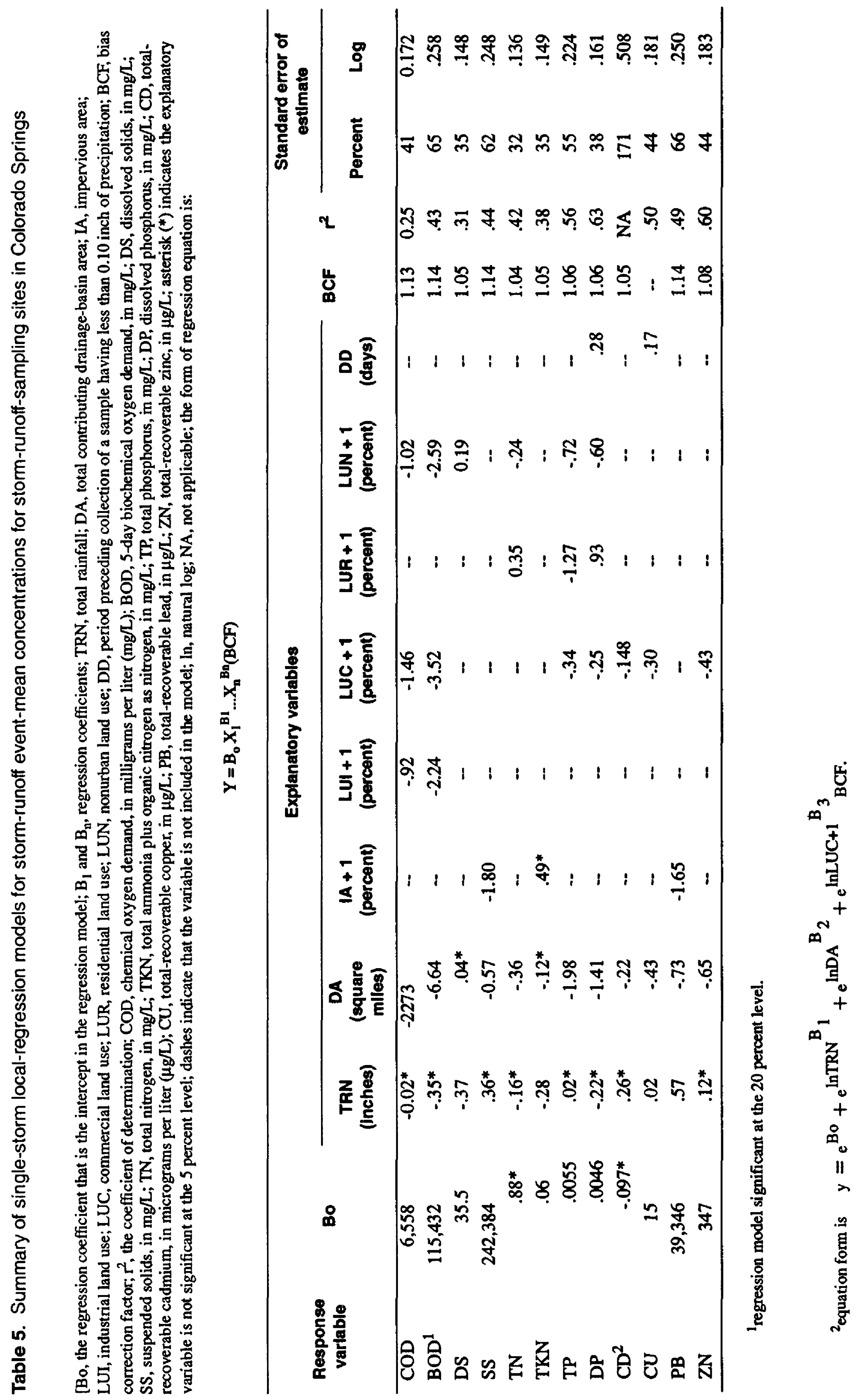

16 Water Quellty of Storm Runoff and Comparison of Procedures for Estimating Storm-Runoff Loads, Voiume, Event-Mean Concentretions, and the Mean Load for a Storm for Selected Propertles and Constifuente for Colorado Springs, Southeastern Colorado, 1992 
range of prediction. Because hydrologic data usually are skewed when using parametric statistical techniques, such as RSQUARE, data need to be transformed to minimize the heteroscedasticy of residuals and to linearize the $x, y$ relation. Response and explanatory variables used in the RSQUARE procedure were log transformed (base 10).

The local-regression models for storm-runoff loads, volume, and event-mean concentrations and the corresponding BCF, $\mathrm{r}^{2}$ values, and the standard error of estimate are listed in tables 4 and 5 . The standard error of estimate is an estimate of the standard deviation about the regression. The smaller the standard error of estimate, the more precise will be the predictions (Driver and Tasker, 1990). The standard error of estimate, in percent, was calculated for all the local-regression models using the following equation (Driver and Tasker, 1990):

$$
\mathrm{SE}=100\left\{\left[\mathrm{e}^{(\mathrm{mse} \times 5.302)}-1\right]\right\}^{0.5}
$$

where

$\mathrm{SE}=$ the standard error of estimate, in percent;

mse $=$ the mean square error, in log (base 10) units; and

$5.302=$ the square of the conversion of log base10 values to natural logs.

The values of $r^{2}$ that use ordinary least-squares regression ranged from 0.57 to 0.86 for storm-runoff loads and volume (table 4) and from 0.25 to 0.63 for storm-runoff event-mean concentrations (table 5). Except for CD, standard errors of estimate range from 43 to 115 percent for storm-runoff loads and volume and 32 to 66 percent for storm-runoff event-mean concentrations (tables 4 and 5). Standard errors of estimate for storm-runoff load and event-mean concentration for CD were 247 (table 4) and 171 percent (table 5). The accuracy of the load, volume, and concentration models cannot be compared on the basis of standard error of estimate because the units of the response variable for each model are different (Hoos and Sisolak, 1993).

The explanatory variables generally had signs (positive or negative) that were hydrologically logical. However, occasionally, the signs on individual explanatory variables seem to be counter intuitive. Driver and Tasker (1990) list the following explanations for why the signs of some regression coefficients (explanatory variables) may be counter intuitive:

1. Significant cross-correlation between explanatory variables causes multicollinearity problems in the local-regression models, however, this is accounted for in the RSQUARE procedure.
2. The process involving the effect of the explanatory variables on the water-quality constituent is not well understood.

3. The explanatory variable is a surrogate for another variable.

4. The apparent significance of an explanatory variable may be due to chance and, therefore, the relation may be spurious.

Use of the local-regression models listed in tables 4 and 5 need to be limited to the ranges of climatic, physical, and land-use (explanatory) variables listed in table 6 . If values outside these ranges are used in the local- regression models, the standard errors may be considerably larger than the values reported in tables 4 and 5. As the local-regression models are applied to drainage-basin areas and to storms larger than the average drainage-basin area or storm volume of the observation sites, the accuracy of estimates of storm-runoff loads, volume, and event-mean concentrations decreases.

\section{Single-Storm Reglonai-Regression Modeis}

Procedures for estimating single-storm runoff loads, volume, and event-mean concentrations were developed by Ellis and others (1984) and Driver and Tasker (1990) for 11 of the 12 properties and constituents required for the permitting process. Regionalregression equations for BOD were not developed. Linear-regression equations were developed from data collected by the NURP. Equations developed by Ellis and others (1984) were developed using NURP data collected in the Denver metropolitan area. The Driver and Tasker (1990) equations were developed from the NURP data base and include sets of equations for three geographically distinct regions delineated by mean annual rainfall. The Colorado Springs area is included in Region 1. Comparison of estimates from these regional-regression models with observed storm-runoff loads, volume, and event-mean concentrations for samples collected in the study area will be useful in selecting the most appropriate method for estimating single-storm runoff loads, volume, and event-mean concentrations.

\section{Comparlson of Observed and Estlmated Single-Storm-Runoff Loads, Volume, and Event-Mean Concentrations}

Storm-runoff loads, volume, and event-mean concentrations estimated from single-storm regional- 
Table 6. Ranges of values of each explanatory values of each explanatory variable used in single-storm local- and regional-regression models

[TRN, total rainfall, in inches; DA, total contributing drainage area, in square miles; IA, impervious area, in percent; DRN, duration of rainfall, in minutes; COD, chemical oxygen demand; DS, dissolved solids; SS, suspended solids; TN, total nitrogen; TKN, total ammonia plus organic nitrogen as nitrogen; TP, total phosphorus; DP, dissolved phosphorus; CD, total-recoverable cadmium; CU, total-recoverable copper; PB, total-recoverable lead; $Z \mathrm{~N}$, total-recoverable zinc; RUN, volume of runoff in cubic feet; dashes, no data available]

\begin{tabular}{|c|c|c|c|c|c|}
\hline $\begin{array}{l}\text { Response } \\
\text { varlable }\end{array}$ & $\begin{array}{l}\text { Explanatory } \\
\text { variable }\end{array}$ & Minimum & Maximum & Mean & Median \\
\hline \multicolumn{6}{|c|}{ Local-regression model for storm-runoff-sampling sites in Colorado Springs } \\
\hline$\left({ }^{1}\right)$ & TRN & 0.05 & 0.41 & 0.17 & 0.14 \\
\hline$\left({ }^{1}\right)$ & DA & .049 & .327 & .17 & .16 \\
\hline (1) & IA & 34.2 & 58.1 & 45.2 & 40.1 \\
\hline SS & DRN & 7.00 & 39.3 & 62.1 & 35.0 \\
\hline \multicolumn{6}{|c|}{ Driver and Tasker (1990) regression model } \\
\hline COD & TRN & .02 & 1.99 & .36 & .26 \\
\hline COD & DA & .05 & 17.50 & 1.18 & .12 \\
\hline COD & IA & - & - & - & -- \\
\hline DS & TRN & .02 & 1.23 & .36 & .28 \\
\hline DS & DA & .01 & 80.5 & 4.92 & .12 \\
\hline DS & IA & 11 & 98.9 & 60.6 & 57 \\
\hline SS & TRN & .03 & 1.99 & .39 & .29 \\
\hline SS & DA & .05 & 17.50 & 1.45 & .12 \\
\hline SS & IA & -- & - & - & -- \\
\hline SS & DRN & 10 & 2,220 & 358 & 231 \\
\hline $\mathrm{TN}$ & TRN & .03 & 1.99 & .41 & .29 \\
\hline $\mathrm{TN}$ & DA & .01 & 80.5 & 6.37 & .11 \\
\hline TN & IA & -- & -- & -- & -- \\
\hline TKN & TRN & .03 & 1.99 & .37 & .28 \\
\hline TKN & DA & .05 & 80.5 & 4.79 & .12 \\
\hline TKN & IA & -- & - & -- & - \\
\hline $\mathrm{TP}$ & TRN & 0.03 & 1.99 & 0.38 & 0.28 \\
\hline $\mathrm{TP}$ & IA & -- & - & -- & -- \\
\hline DP & TRN & .03 & 1.99 & .39 & .28 \\
\hline DP & $\mathrm{DA}$ & .01 & 4.00 & .50 & .11 \\
\hline DP & IA & - & - & -- & -- \\
\hline$C D$ & TRN & .03 & .93 & .26 & .22 \\
\hline $\mathrm{CD}$ & DA & 0.01 & 3.03 & 0.36 & 0.12 \\
\hline $\mathrm{CD}$ & IA & - & -- & -- & -- \\
\hline $\mathrm{CU}$ & TRN & .02 & 1.99 & .37 & .27 \\
\hline $\mathrm{CU}$ & DA & .01 & 4.00 & .55 & .12 \\
\hline $\mathrm{CU}$ & IA & -- & -- & - & -- \\
\hline $\mathrm{PB}$ & TRN & .02 & 1.99 & .39 & .28 \\
\hline PB & DA & .004 & 4.00 & .47 & .11 \\
\hline PB & IA & -- & -- & -- & -- \\
\hline $\mathrm{ZN}$ & TRN & .02 & 1.99 & .39 & .28 \\
\hline $\mathrm{ZN}$ & DA & .01 & 4.00 & .53 & .12 \\
\hline $\mathrm{ZN}$ & IA & - & -- & - & -- \\
\hline
\end{tabular}


Table 6. Ranges of values of each explanatory values of each explanatory variable used in single-storm local- and regional-regression models--Continued

\begin{tabular}{cccccc}
\hline $\begin{array}{c}\text { Response } \\
\text { varlable }\end{array}$ & $\begin{array}{c}\text { Explanatory } \\
\text { varlabla }\end{array}$ & MInimum & Maxlmum & Mean & Medlan \\
\hline RUN & TRN & .02 & 1.99 & .36 & .26 \\
RUN & DA & .004 & 80.5 & 2.93 & .11 \\
RUN & IA & 0 & 98.9 & 56.7 & 57 \\
& \multicolumn{2}{c}{ Small basins [Ellis and others } & $(1984)]$ regression model & \\
$\left({ }^{2}\right)$ & TRN & .03 & 1.99 & .35 & - \\
$\left({ }^{2}\right)$ & DA & .09 & .63 & .20 & .12 \\
$\left({ }^{2}\right)$ & IA & .60 & 91 & 36.7 & 38 \\
& Small and large basins [Ellis and others (1984)] regression model & \\
$\left({ }^{2}\right)$ & TRN & - & -- & - & - \\
$\left({ }^{2}\right)$ & DA & 0.09 & 24.7 & 6.1 & 0.20 \\
$\left({ }^{2}\right)$ & IA & .6 & 91 & 31.8 & 24 \\
\hline
\end{tabular}

${ }^{1}$ Includes storm-runoff load and event-mean concentration for chemical oxygen demand, dissolved solids, suspended solids, total nitrogen, total ammonia plus organic nitrogen as nitrogen, total phosphorus, dissolved phosphorus, total-recoverable cadmium, total-recoverable copper, total-recoverable lead, total-recoverable zinc, and volume of runoff for RUN.

${ }^{2}$ Includes storm-runoff load for chemical oxygen demand, suspended solids, total nitrogen, total phosphorus, total-recoverable lead, total-recoverable zinc, and volume of runoff for RUN.

regression models were compared to observed values from data collected at five sites in the study area in 1992 (fig. 1, table 1). The response variables estimated by Driver and Tasker (1990) are storm-runoff loads for COD, SS, DS, TN, TKN, TP, DP, CD, CU, PB, and ZN; storm-runoff volume, and event-mean concentrations for COD, SS, DS, TN, TKN, TP, DP, CD, CU, PB, and ZN. The response variables estimated by Ellis and others (1984) are storm-runoff loads for COD, SS, TN, TP, PB, and $\mathrm{ZN}$ and storm-runoff volume. Driver and Tasker (1990) developed two sets of single-storm regionalregression models for storm-runoff loads and volume. The first set of models was based on a stepwise regression analysis of 13 explanatory variables including TRN, DA, IA, land-use, and regional climatic variables. The second set of models was based on three explanatory variables-TRN, DA, and IA. The single-storm regional-regression models for storm-runoff event-mean concentrations are based on stepwise regression analysis of the same 13 explanatory variables used to develop models for storm-runoff load and volume. Single-storm regional-regression models developed by Ellis and others (1984) for storm-runoff loads and volume were based on three explanatory variables-TRN, DA, and IA.

Comparisons of observed and estimated stormrunoff loads, volume, and event-mean concentrations were made using the root-mean-square error (RMSE) of estimate from the equation:

$$
\text { RMSE }=\left[\frac{1}{n} \sum_{i=1}^{n}\left(\log O_{i}-\log E_{i}\right)^{2}\right]^{\frac{1}{2}}
$$

where

RMSE = the root-mean-square error in log units (base 10);

$\mathrm{O}_{\mathrm{i}} \quad=$ ith observed value;

$\mathrm{E}_{\mathbf{i}} \quad=$ ith estimated value from the regionalregression model; and

n = the number of observations in the data set. Generally, when compared to observed values, the 3-variable models that were developed by Driver and Tasker (1990) for estimating storm-runoff loads had the smallest RMSE (table 7). For estimates of storm-runoff volume, when compared to observed values, the multivariate model developed by Driver and Tasker (1990) had the smaller RMSE (table 7).

An evaluation of residuals from a comparison of observed and estimated storm-runoff loads, volume, and event-mean concentrations can be used to determine the direction of bias of estimated values compared to observed values. Compared to observed values, most regional-regression models tended to overestimate (negative sign in table 8) storm-runoff loads, volume, and event-mean concentrations. However, the direction of bias was not consistent for all properties and constituents and runoff volume (table 8). 
Table 7. Root-mean-square error from comparison of observed storm-runoff loads and volumes and estimated storm-runoff loads and volumes from single-storm regional-regression models

[COD, chemical oxygen demand, in pounds; DS, dissolved solids, in pounds; SS, suspended solids, in pounds; TN, total nitrogen, in pounds; TKN, total ammonia plus organic nitrogen as nitrogen, in pounds; TP, total phosphorus, in pounds; DP, dissolved phosphorus, in pounds; $C D$, total-recoverable cadmium, in pounds; $\mathrm{CU}$, total-recoverable copper, in pounds; $\mathrm{PB}$, total-recoverable lead, in pounds; $\mathrm{ZN}$, total-recoverable zinc, in pounds; $\mathrm{RUN}$, volume, in cubic feet; dashes indicate not available]

\begin{tabular}{|c|c|c|c|c|}
\hline \multirow{3}{*}{ Response varlable } & \multicolumn{4}{|c|}{ Root-mean-square error in log units } \\
\hline & \multicolumn{2}{|c|}{$\begin{array}{l}\text { Regionai-regression modals from Drlver-Tasker } \\
\text { (1990) }\end{array}$} & \multicolumn{2}{|c|}{$\begin{array}{c}\text { Reglonal-regression models from Eilis snd } \\
\text { others (1984) }\end{array}$} \\
\hline & 3-varlable model ${ }^{1}$ & Multivarlate model ${ }^{2}$ & Small drainage basins ${ }^{3}$ & $\begin{array}{l}\text { Small snd large } \\
\text { drainage bssins }\end{array}$ \\
\hline COD & 0.353 & 0.738 & 0.421 & 0.384 \\
\hline DS & .396 & .423 & - & -- \\
\hline SS & .463 & 3.70 & .490 & .549 \\
\hline TN & .256 & .669 & .336 & .279 \\
\hline TKN & .960 & 1.11 & - & -- \\
\hline TP & .598 & 1.13 & .461 & .469 \\
\hline DP & 637 & 1.12 & -- & -- \\
\hline $\mathrm{CD}^{5}$ & .409 & .626 & -- & -- \\
\hline $\mathrm{CU}$ & .666 & 1.15 & -- & .- \\
\hline PB & .668 & .708 & .782 & .583 \\
\hline $\mathrm{ZN}$ & .421 & .494 & .517 & .495 \\
\hline RUN & - & .332 & .375 & .354 \\
\hline
\end{tabular}

${ }^{1}$ Equations from table 3 in Driver and Tasker (1990).

${ }^{2}$ Equations from table 1 in Driver and Tasker (1990).

${ }^{3}$ Equations from table 19 in Ellis and others (1984).

${ }^{4}$ Equations from table 20 in Ellis and others (1984).

${ }^{5}$ Root-mean-square error computed withont censored data.

Differences between the observed and estimated storm-runoff loads, volume, and event-mean concentrations can be explained by the following:

1. Hydrologic conditions controlling the detection of properties and constituents specific to Colorado Springs are not explained by the Driver and Tasker (1990) models.

2. Data collected for certain properties and constituents for the NURP studies might not be reprosentative of the Colorado Springs area.

3. Regional-regression models were developed using a larger range of drainage-basin areas than the drainage-basin areas used for this study (tables 1 and 6). Therefore, regional-regression models might be biased and might be overestimating storm-runoff loads, volume, and event-mean concentrations for smaller drainage basins.

\section{Procedures for Adjustment of Estimates from Single-Storm Regional-Regression Models Using Local Data}

When compared to observed data, single-storm regional-regression models tended to overestimate storm-runoff loads, volume, and event-mean concentrations. As a result, single-storm local-regression models would be the preferred method for estimating storm-runoff loads, volume, and event-mean concentrations because the single-storm local-regression models were developed using local data based on the climatic, physical, and land-use characteristics of the Colorado Springs area. However, only a small number of observations (30--snowmelt samples not included) were available for the development of the single-storm local-regression models, and the use of the singlestorm local-regression models need to be limited to estimates within the ranges of the explanatory variables used to develop the model (table 6). Single-storm regional-regression models are based on a large number of observations ( 65 to 348), and the explanatory variables have a wider range than the explanatory vari- 
Table 8. Summary of residual values for observed minus estimated values of storm-runoff loads, volume, and event-mean concentrations

[DT1, regional-regression model from table 1 in Driver and Tasker (1990); DT3, regional-regression model from table 3 in Driver and Tasker (1990); EL19, regional-regression model from table 19 in Ellis and others (1984); EL20, regional regression model from table 20 in Ellis and others (1984); DT5, regionalregression model from table $S$ in Driver and Tasker (1990); load, storm-runoff loads, in pounds; mg/L, storm-runoff event-mean concentration, in milligrams per liter; $\mu \mathrm{g} / \mathrm{L}$, storm-runoff event-mean concentration, in micrograms per liter; dashes indicate not data available; negative number in the table means the estimated value from the regional regression model is greater than the observed value; positive number in the table means the estimated value from the regional-regression model is less than the observed value]

\begin{tabular}{|c|c|c|c|c|c|c|}
\hline \multirow{2}{*}{ Response varlable } & \multirow{2}{*}{$\begin{array}{l}\text { Regression } \\
\text { model }\end{array}$} & \multicolumn{5}{|c|}{ Residual values } \\
\hline & & Minimum & Maximum & $\begin{array}{c}\text { 75th } \\
\text { percentlle }\end{array}$ & Medlan & Mean \\
\hline \multirow[t]{5}{*}{ Chemical oxygen demand (COD) } & DT1 load & $-2,525$ & 1,179 & -1.4 & -175 & -347 \\
\hline & DT3 load & -349 & 1,188 & 39 & -18 & 16 \\
\hline & El19 load & -455 & 1,138 & 44 & 6 & -13 \\
\hline & E120 load & -323 & 12,155 & 60 & 11 & 20 \\
\hline & DT5 mg/L & $-1,275$ & 265 & -28 & -433 & -443 \\
\hline \multirow[t]{3}{*}{ Dissolved solids (DS) } & DT1 load & -85 & 226 & 48 & 12.4 & 33 \\
\hline & DT3 load & -124 & 206 & 36 & -0.05 & 18 \\
\hline & DT5 mg/L & -126 & 49 & -7.4 & -62 & -48 \\
\hline \multirow[t]{5}{*}{ Suspended solids (SS) } & DT1 load & 27 & 2,130 & 756 & 310 & 448 \\
\hline & DT3 load & $-1,021$ & 1,064 & 148 & -31 & 13 \\
\hline & El19 load & -678 & 1,396 & 372 & 36 & 159 \\
\hline & El20 load & $-1,019$ & 1,144 & 326 & 22 & 87 \\
\hline & DT5 mg/L & -489 & 702 & 193 & -82 & -34 \\
\hline \multirow[t]{5}{*}{ Total nitrogen (TN) } & DT1 load & 0.43 & 79 & 8.5 & 4.0 & 4.7 \\
\hline & DT3 load & .39 & 7.09 & 2.8 & 2.1 & 1.8 \\
\hline & E119 load & .44 & 12.3 & 3.9 & 2.6 & 2.2 \\
\hline & El20 load & .55 & 9.52 & 2.8 & 1.9 & 1.9 \\
\hline & D'T5 mg/L & .71 & 22 & 12 & 5.4 & 4.4 \\
\hline \multirow{3}{*}{$\begin{array}{l}\text { Total ammonia plus organic } \\
\text { nitrogen as nitrogen (TKN) }\end{array}$} & DT1 load & -42 & 1.5 & -1.4 & -3.8 & -7.6 \\
\hline & DT3 load & -16 & -.72 & -1.7 & -4.0 & -5.0 \\
\hline & DT5 mg/L & -34 & -1.2 & -2.3 & -10 & -12 \\
\hline \multirow[t]{5}{*}{ Total phosphorus (TP) } & DT1 load & -22 & .95 & -0.12 & -.60 & -3.1 \\
\hline & DT3 load & -1.9 & .22 & -.13 & -.47 & -0.60 \\
\hline & El19 load & .04 & 2.6 & .91 & .63 & .72 \\
\hline & El20 load & .04 & 2.7 & .92 & .65 & .74 \\
\hline & DT5 mg/L & -8.3 & .63 & -.21 & -2.4 & -3.1 \\
\hline \multirow[t]{3}{*}{ Dissolved phosphorus (DP) } & DT1 load & -9.6 & .31 & -.06 & -.24 & -1.5 \\
\hline & DT3 load & -.95 & .06 & -.12 & -.31 & -.33 \\
\hline & DT5 mg/L & -4.6 & .13 & -.02 & -.75 & -1.6 \\
\hline
\end{tabular}


Table 8. Summary of residual values for observed minus estimated values of storm-runoff loads, volume, and event-mean concentrations--Continued

\begin{tabular}{|c|c|c|c|c|c|c|}
\hline \multirow[b]{2}{*}{ Response varlable } & \multirow{2}{*}{$\begin{array}{l}\text { Regression } \\
\text { model }\end{array}$} & \multicolumn{5}{|c|}{ Residual valuea } \\
\hline & & Minimum & Maximum & $\begin{array}{c}\text { 75th } \\
\text { percentile }\end{array}$ & Median & Mean \\
\hline \multirow{3}{*}{$\begin{array}{l}\text { Total-recoverable cadmium } \\
\text { (CD) }\end{array}$} & DT1 load & -0.02 & 0.001 & -0.0002 & -0.0006 & -0.002 \\
\hline & DT3 load & -.002 & .002 & .0003 & -.00006 & -.0003 \\
\hline & DT5 $\mu \mathrm{g} / \mathrm{L}$ & -2.8 & .71 & -.07 & -.69 & -.82 \\
\hline \multirow[t]{3}{*}{ Total-recoverable copper (CU) } & DTI load & -.77 & -.02 & -.06 & -.09 & -.15 \\
\hline & DT3 load & -.13 & .02 & -.01 & -.03 & -.03 \\
\hline & DT5 $\mu \mathrm{g} / 1$ & -168 & -30 & -46 & -77 & -82 \\
\hline \multirow[t]{5}{*}{ Total-recoverable lead (PB) } & DTI load & -.66 & .47 & .11 & -.06 & -.08 \\
\hline & DT3 load & -.62 & .43 & -.002 & -.09 & -.12 \\
\hline & El19 load & -1.1 & .36 & .03 & -.11 & -.21 \\
\hline & El20 load & -.35 & $: 63$ & .07 & -.02 & -.003 \\
\hline & DT5 $\mu \mathrm{g} / \mathrm{L}$ & -315 & 200 & 18 & -124 & -90 \\
\hline \multirow[t]{5}{*}{ Total-recoverable zinc (ZN) } & DT1 load & -.64 & 1.1 & .19 & -.009 & .02 \\
\hline & DT 3 load & -.69 & .95 & .14 & -.007 & .03 \\
\hline & E119 load & -.87 & 1.0 & .14 & -.009 & -.04 \\
\hline & El20 load & -.76 & 1.0 & .15 & -.006 & -.01 \\
\hline & DT5 $\mu \mathrm{g} / \mathrm{L}$ & -651 & 869 & -133 & -288 & -238 \\
\hline \multirow[t]{3}{*}{ Volume of runoff (RUN) } & DT1 cubic feet & $-31,592$ & 51,359 & 4,483 & 445 & 1,439 \\
\hline & El19 cubic feet & $-48,818$ & 35,965 & 2,417 & 138 & $-4,928$ \\
\hline & EL20 cubic feet & $-32,342$ & 47,411 & 4,794 & 964 & 1,028 \\
\hline
\end{tabular}

${ }^{1}$ Computed using uncensored data.
ables used in the single-storm local-regression models (table 6). It would be useful if single-storm local- and regional-regression models could be combined to take advantage of the strengths of both regression models while minimizing the respective deficiencies of the regression models.

Hoos (1991) presented a procedure to adjust single-storm regional-regression models using local data. Hoos and Sisolak (1993) evaluated different model-adjustment procedures (MAP's) and established criteria for selecting the appropriate MAP. The MAP is in the form of a regression analysis. Local data are used as the calibration data set. In one MAP (MAP-R-P), log-transformed local (observed) data (response variables) are regressed against the log-transformed estimates from the single-storm regional-regression models (explanatory variables). The resulting equations are the adjusted regression models used to predict storm-runoff loads, volume, or event-mean concentrations at an unmonitored site. Another form of MAP (MAP-W) is simply the weighting of $\log$-transformed estimates from local- and regional-regression models. The equations for the two MAPs for adjusting the regional-regression equations are Hoos and Sisolak, (1993):

1. MAP-R-P calibration equation:

$$
\log O_{i}=\log B_{0}+B_{1} \log R_{E i}
$$

where

$\mathrm{O}_{i}=$ the observed value of storm-runoff load, volume, or event-mean concentration at site $i$

$B_{0}$ and $B_{1}=$ coefficients fitted from a simple linearregression analysis of the calibration data set

(observed data); and

$\mathrm{R}_{\mathrm{E} i} \quad=$ the regional estimate; estimated value of storm-runoff load, runoff volume, or event-mean concentration from the unadjusted singlestorm regional-regression model at site $i$. 
The adjusted regional-regression model (from the detransformation of eq. 7) is then:

$$
\mathrm{AR}_{\mathrm{Ei}}=\mathrm{B}_{\mathrm{o}} \mathrm{R}_{\mathrm{Ei}}^{\mathrm{B} 1}(\mathrm{BCF})
$$

where

$$
\begin{aligned}
& A R_{E i}=\text { the adjusted single-storm regional- } \\
& \text { regression estimate. } \\
& \text { 2. MAP-W calibration equation: }
\end{aligned}
$$

$$
\log \mathrm{O}_{i}=\{(\mathrm{J} \times \log \mathrm{RE})[(1-\mathrm{J}) \times \log \mathrm{LOC}]\}
$$

where

$$
J=\left\{\left(\operatorname{SEloc}^{2}\right) /\left[\left(\operatorname{SEloc}^{2}\right)+\left(\text { SEreg }^{2}\right)\right]\right\}
$$

where

SEloc = the standard error of estimate, in log units for the single-storm local-regression model;

SEreg $=$ the standard error of estimate, in log units as reported in Driver and Tasker (1990)

for the single-storm regional-regression model; and

LOC $=$ estimated value from the single-storm local-regression equation.

The weighted single-storm regional-regression model (the detransformation of eq. 10) then is:

$$
\mathrm{WE}=\left\{\left(\mathrm{RE}^{\mathrm{J}}\right) \times\left(\mathrm{LOC}^{(1-\mathrm{J})}\right)\right\} \times \mathrm{BCF},
$$

where

$\mathrm{WE}$ = adjusted (weighted) single-storm regionalregression estimate.

Selection of the appropriate MAP needs to be made based on whether or not observed and estimated data are correlated and on if there is a consistent bias between the local-data (observed) and estimated-data pairs (fig. 2, step 3). Correlation between observed and estimated data was evaluated by analyzing the significance of Spearman's rho (Iman and Conover, 1983), and bias was determined using the signed-rank test on the paired data (Iman and Conover, 1983). If the null hypothesis (a significant correlation does not exist between observed and estimated values or a consistent bias does not exist between observed and estimated values) for either test is not rejected at a selected level of significance, then correlation between observed data and explanatory variables is determined by examining correlation coefficients, $\mathrm{r}^{2}$ (fig. 2, step 4) (Hoos and Sisolak, 1993).
After evaluating Spearman's rho and the signedrank test for the Colorado Springs data set, the appropriate MAPs were selected for adjusting the regionalregression models using local data based on the flow chart in figure 2. The RMSE was large for all comparisons between observed values and values estimated using single-storm regional-regression equations (tables 7,9, and 10). Because observed values and estimated values from single-storm regional-regression equations were highly correlated and had a consistent direction of bias, MAP-R-P (fig. 2, steps 2 and 3) was selected for adjusting storm-runoff-load equations for TN, TKN, TP, DP, CU, and PB and for adjusting the storm-runoff event-mean concentration equations for TP, CU, and PB. Observed and estimated values for the remaining storm-runoff loads and event-mean concentrations of the remaining constituents were not highly correlated or did not have a consistent direction of bias, or both; however, the remaining observed values were significantly correlated with some explanatory variables. Therefore, MAP-W (fig. 2, step 3) was selected for adjusting storm-runoff-load equations for COD, $\mathrm{DS}, \mathrm{SS}, \mathrm{CD}$, and $\mathrm{ZN}$; for adjusting equations for estimating volume of runoff; and for adjusting event-mean concentration equations for COD, DS, SS, TN, TKN, $\mathrm{DP}, \mathrm{CD}$, and $\mathrm{ZN}$.

When compared to observed storm-runoff loads and volume, the three-variable single-storm regionalregression models for storm-runoff loads and the multivariate single-storm regional-regression models for storm-runoff volume that were developed by Driver and Tasker (1990) had the smallest RMSE of all of the single-storm regional-regression models tested. These models and the 13-variable single-storm regionalregression models for event-mean concentration were adjusted using MAPs.

The MAP's decreased model error in estimating storm-runoff loads, volume, and event-mean concentrations, except for the equation for event-mean concentration for $\mathrm{CD}$. Reduction of error, in percent, ranged from $-1,980$ to -10 percent (based on data in tables 9 and 10). The effect of MAP's on estimated storm-runoff loads and event-mean concentrations can be illustrated by plotting observed values, estimates from regional-regression models, and estimates from regional-regression models adjusted using MAPs. Two examples from site 2 are presented, one for each MAP-MAP-R-P (TP) and MAP-W (TKN) (figs. 3 and 4). In both cases, the estimates of storm-runoff load and event-mean concentration obtained using MAP-R-P (fig. 3) and MAP-W (fig. 4) were closer to the observed value than the estimate from the regionalregression equation. Adjusted models, developed using MAP-R-P and MAP W, for estimating stormrunoff loads, volume, and event-mean concentrations are listed in tables 11 and 12. 


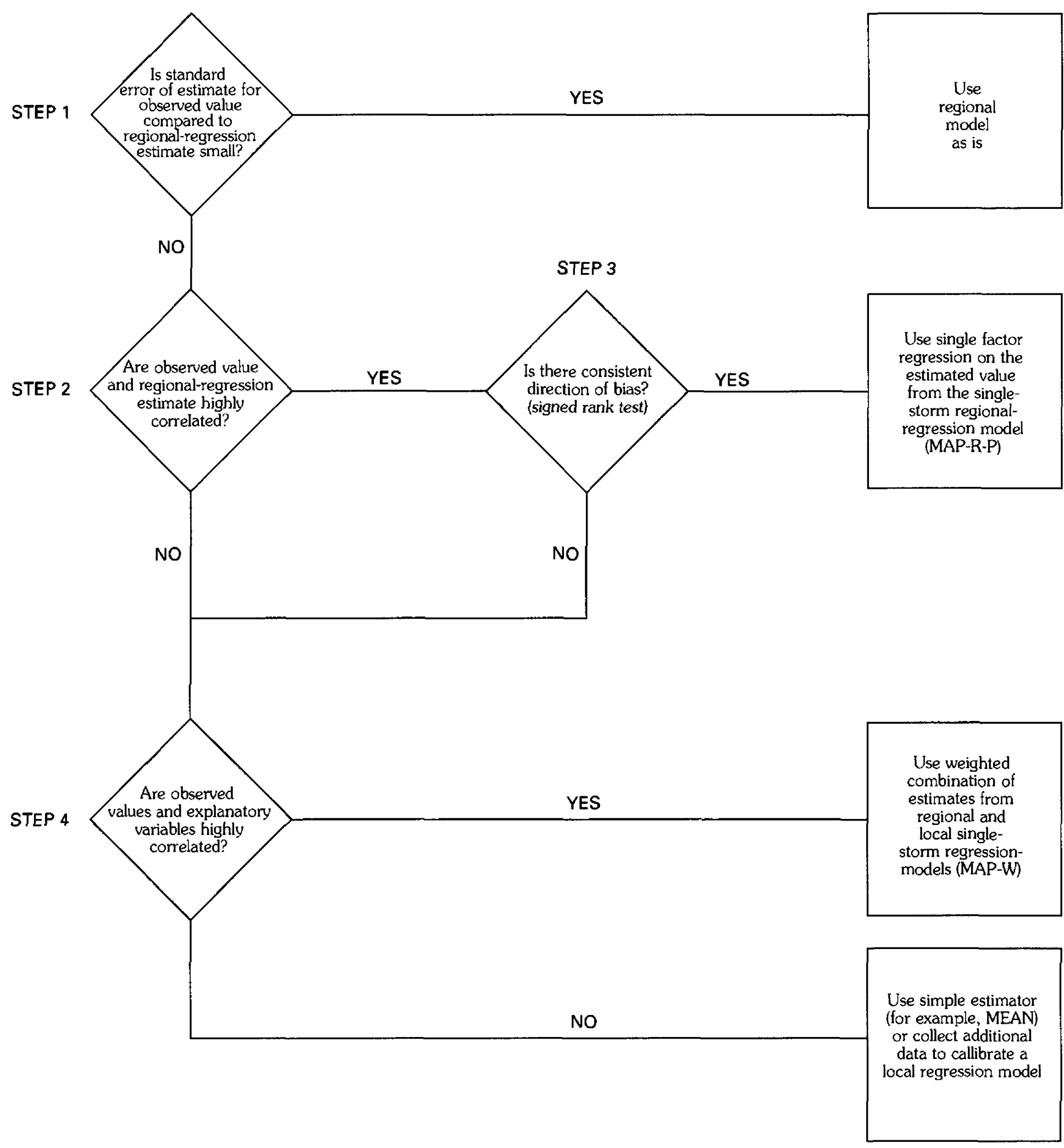

Figure 2. Flowchart for selection of model adjustment procedures (modified from Hoos and Sisolak, 1993). 
Table 9. Effect of model-adjustment procedures on root-mean-square error and standard error of estimate for storm-runoff loads and volume

[MAP-R-P, observed data regressed against the regional estimate; MAP-W, the weighted combimation of local-regression estimate and regional-regression estimate; COD, chemical oxygen demand; DS, dissolved solids; SS, suspended solids; TN, total nitrogen; TKN, total ammonia plns organic nitrogen as nitrogen; TP, total phosphorus; DP, dissolved phosphorus; CD, total-recoverable cadmium; CU, total-recoverable copper, PB, total-recoverable lead; $\mathrm{ZN}$, total-recoverable zinc; RUN, volume; dashes indicate no data]

\begin{tabular}{|c|c|c|c|c|c|c|c|c|}
\hline \multirow{4}{*}{$\begin{array}{l}\text { Response } \\
\text { variable }\end{array}$} & \multicolumn{4}{|c|}{ Root-mean-square error } & \multicolumn{4}{|c|}{ Standard error of estimate } \\
\hline & \multicolumn{4}{|c|}{ Reglonal-regression model from Driver-Tasker (1990) } & \multirow{2}{*}{\multicolumn{2}{|c|}{ MAP-R-P }} & \multirow{2}{*}{\multicolumn{2}{|c|}{ MAP-W }} \\
\hline & \multicolumn{2}{|c|}{ 3-varlable models ${ }^{1}$} & \multicolumn{2}{|c|}{ 13-varlable models ${ }^{2}$} & & & & \\
\hline & (percent) & (log units) & (percent) & (log units) & (percent) & (log units) & (percent) & (log units) \\
\hline COD & 97 & 0.353 & - & -- & - & -- & 65 & 0.258 \\
\hline DS & 114 & .396 & -- & -- & -- & - & 59 & .237 \\
\hline SS & 145 & .463 & -- & -- & - & -- & 102 & .366 \\
\hline $\mathrm{TN}$ & 68 & .256 & -- & - & 19 & 0.283 & -- & - \\
\hline TKN & 1,147 & .960 & -- & -- & 106 & .377 & - & - \\
\hline TP & 238 & .598 & - & -- & 109 & .384 & - & - \\
\hline DP & 276 & .637 & - & - & 95 & .348 & -- & - \\
\hline $\mathrm{CD}^{3}$ & 119 & .409 & - & -- & -- & - & 81 & .308 \\
\hline $\mathrm{CU}$ & 308 & .666 & - & - & 116 & .402 & - & - \\
\hline $\mathrm{PB}$ & 311 & .668 & -- & -- & 191 & .538 & - & - \\
\hline $\mathrm{ZN}$ & 125 & .421 & - & -- & -- & - & 115 & .398 \\
\hline RUN & -- & -- & 89 & .332 & -- & -- & 29 & .124 \\
\hline
\end{tabular}

${ }^{1}$ Equations from table 3 in Driver and Tasker (1990).

${ }^{2}$ Equations from table 1 in Driver and Tasker (1990).

${ }^{3}$ Computed without censored data.

Table 10. Effect of model-adjustment procedures on standard error of estimate for storm-runoff event-mean concentrations

[MAP-R-P, local data regressed against the regional estimate; MAP-W, the weighted combination of local-regression estimate and regional-regression estimate; COD, chemical oxygen demand; DS, dissolved solids; SS, suspended solids; TN, total nitrogen; TKN, total ammonia plus organic nitrogen as nitrogen; TP, total phosphorus; DP, dissolved phosphorus; CD, total-recoverable cadmium; CU, total-recoverable copper; $P B$, total-recoverable lead; ZN, total-recoverable zinc; dashes indicate not applicable]

\begin{tabular}{|c|c|c|c|c|c|c|}
\hline \multirow{3}{*}{$\begin{array}{c}\text { Response } \\
\text { variable }\end{array}$} & \multirow{2}{*}{\multicolumn{2}{|c|}{ 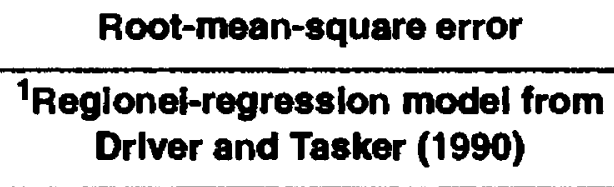 }} & \multicolumn{4}{|c|}{ Standard error of estimate } \\
\hline & & & \multicolumn{2}{|c|}{ MAP-R-P } & \multicolumn{2}{|c|}{ MAP-W } \\
\hline & (percent) & (log units) & (percent) & (log unlts) & (percent) & (log units) \\
\hline COD & 201 & 0.553 & -- & - & 41 & 0.172 \\
\hline DS & 69 & .272 & -- & -- & 45 & .188 \\
\hline SS & 74 & .286 & -- & - & 64 & .253 \\
\hline TN & 282 & .643 & -- & -. & 40 & .168 \\
\hline TKN & 2,078 & 1.07 & - & - & 98 & .356 \\
\hline TP & 1,398 & .998 & 73 & 0.285 & -. & -- \\
\hline DP & 1,220 & .972 & -- & - & 176 & .516 \\
\hline $\mathrm{CD}^{2}$ & 86 & .322 & - & -- & 238 & .598 \\
\hline $\mathrm{CU}$ & 459 & .764 & 54 & .219 & -- & -- \\
\hline PB & 186 & .531 & 70 & .273 & -- & -- \\
\hline $\mathrm{ZN}$ & 121 & .413 & -- & -- & 44 & .183 \\
\hline
\end{tabular}

${ }^{1}$ Equations from table 5 in Driver and Tasker (1990).

${ }^{2}$ Computed without censored data. 


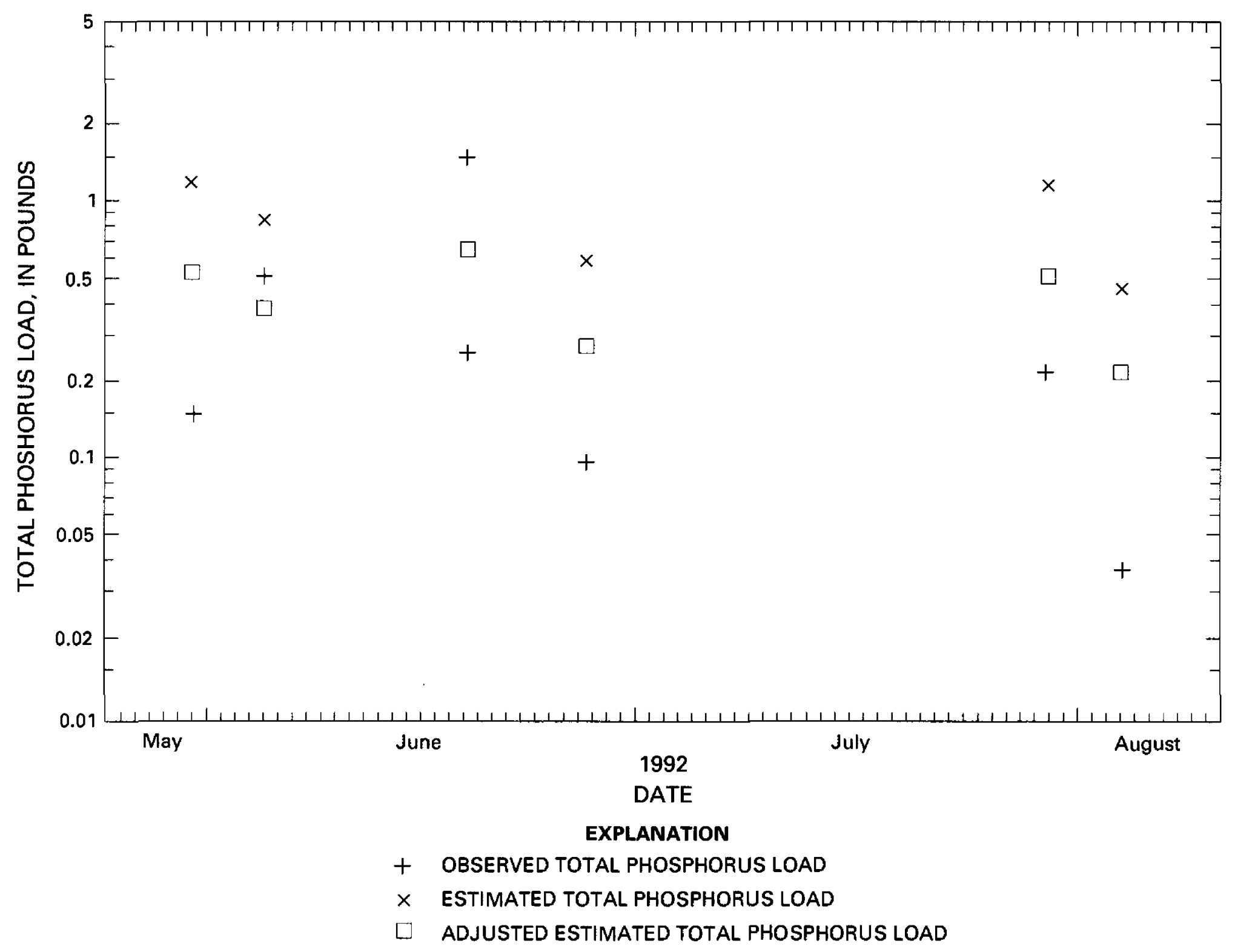

Figure 3. Observed total-phosphorus, estimated total-phosphorus, and adjusted estimates of total-phosphorus loads for storm-runoff load at site 2. 


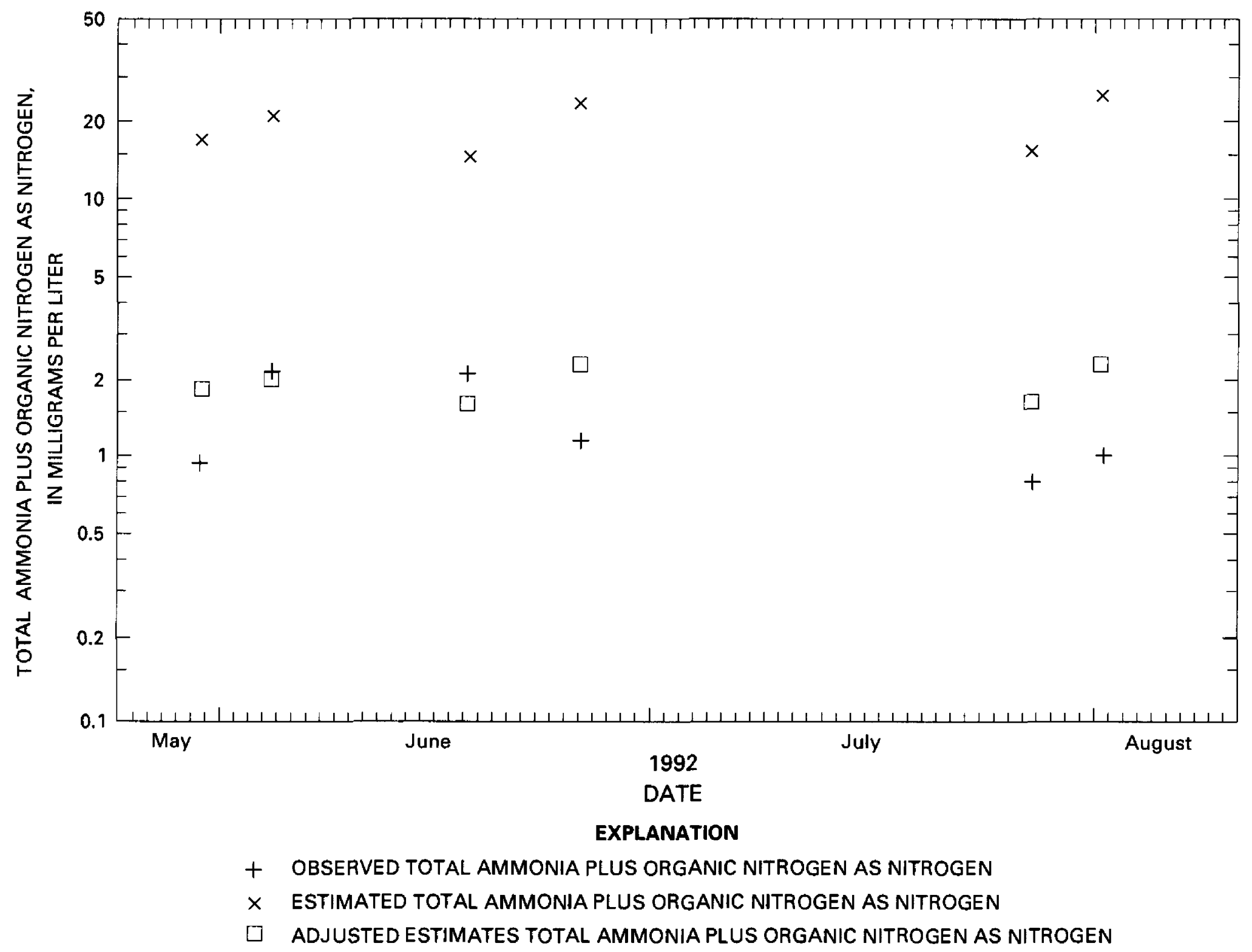

Figure 4. Observed total ammonia plus organic nitrogen as nitrogen, estimated total ammonia plus organic nitrogen as nitrogen, and adjusted estimates of total ammonia plus organic nitrogen as nitrogen for storm-runoff event-mean concentrations at site 2. 
Table 11. Summary of adjusted models for storm-runoff loads and volume

[MAP-R-P, regression of observed data against regional-regression; MAP-W, weighted combination of local-regression estimate and regional-regression estimate; Bo, B1, coefficients fitted from a simple linear regression analysis of the calibration data set (local data base); BCF, the bias correction factor; J, weighting factor; COD, chemical oxygen demand loads; DS, dissolved-solids load; SS, suspended-solids load; TN, total nitrogen load; TKN, total ammonia plus organic nitrogen load; TP, total phosphorus load; DP, dissolved phosphorus load; CD, total-recoverable cadmium load; CU, total-recoverable copper load; PB, total-recoverable lead load; ZN, total-recoverable zinc load; RUN, storm-runoff volume; dashes indicate not applicable; y, response variable; RE, estimate from regional regression; LOC, estimate from local regression]

\begin{tabular}{|c|c|c|c|c|c|c|}
\hline \multirow{3}{*}{$\begin{array}{l}\text { Response } \\
\text { variable }\end{array}$} & \multicolumn{6}{|c|}{ Model-adjustment procedure } \\
\hline & \multicolumn{3}{|c|}{ MAP-R-P' } & \multicolumn{3}{|c|}{ MAP-W ${ }^{2}$} \\
\hline & Bo & B1 & BCF & $\mathbf{J}$ & $1 \sqrt{1-}$ & BCF \\
\hline COD & -- & $\overline{--}$ & $\overline{--}$ & 0.27 & 0.73 & 1.13 \\
\hline DS & - & -- & -- & .35 & .65 & 1.14 \\
\hline SS & - & -- & -- & .23 & .77 & 1.24 \\
\hline $\mathrm{TN}$ & 0.82 & 0.71 & 1.23 & - & -- & $\ldots$ \\
\hline TKN & .23 & .61 & 1.40 & - & -- & -- \\
\hline $\mathrm{TP}$ & .33 & .91 & 1.35 & - & - & -- \\
\hline DP & .24 & .82 & 1.32 & - & -- & -- \\
\hline $\mathrm{CD}$ & -- & -- & -. & .85 & .15 & 1.14 \\
\hline $\mathrm{CU}$ & .14 & .77 & 1.42 & - & -- & -- \\
\hline PB & .20 & .69 & 1.80 & - & - & -- \\
\hline $\mathrm{ZN}$ & - & - & -- & .42 & .58 & 1.18 \\
\hline RUN & -- & -- & -- & .24 & .76 & 1.04 \\
\hline
\end{tabular}

${ }^{1}$ Form of equation is $\mathrm{y}=\mathrm{BoR} \mathrm{Ri}^{\mathrm{B1}} \mathrm{BCF}$.

${ }^{2}$ Form of equation is $y=\left(R_{E G}\right)\left(\operatorname{LOC}^{(1-J)}\right) B C F$.

Table 12. Summary of adjusted models for storm-runoff event-mean concentrations

[MAP-R-P, regression of local data against regional estimate; MAP-W, weighted combination of local-regression estimate and regional-regression estimate; Bo, B 1, coefficients fitted from a simple linear regression analysis of the calibration data set (local data base); BCF, bias correction factor; J, weighting factor: COD, chemical oxygen demand event-mean concentration; DS, dissolved-solids event-mean concentration; SS, suspended-solids event-mean concentration; TN, total nitrogen event-mean concentration; TKN, total ammonia plus organic nitrogen event-mean concentration; TP, total phosphorus event-mean concentration; DP, dissolved phosphorus event-mean concentration; $C D$, total-recoverable cadmium event-mean concentration; $C U$, total-recoverable copper event-mean concentration; PB, total-recoverable lead event-mean concentration; $Z \mathrm{ZN}$, total-recoverable zinc event-mean concentration; dashes indicate not applicable; $y$, response variable; $R E$, estimate from regional model; LOC, estimate from local model]

\begin{tabular}{|c|c|c|c|c|c|c|}
\hline \multirow{3}{*}{$\begin{array}{l}\text { Rasponse } \\
\text { variable }\end{array}$} & \multicolumn{6}{|c|}{ Model-adjustment procedure } \\
\hline & \multicolumn{3}{|c|}{ MAP-R-P1 } & \multicolumn{3}{|c|}{ MAP-W ${ }^{2}$} \\
\hline & Bo & B1 & BCP & $\mathbf{J}$ & $1 \sqrt{ }$ & BCF \\
\hline COD & -- & 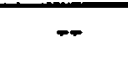 & -- & 0.33 & 0.67 & 1.08 \\
\hline DS & -- & -- & -- & .18 & .82 & 1.05 \\
\hline SS & -- & - & -- & .24 & .76 & 1.14 \\
\hline TN & - & -- & -- & .33 & .67 & 1.07 \\
\hline TKN & -- & -- & -- & .28 & .72 & 1.06 \\
\hline TP & 0.48 & -0.26 & 1.2 & - & -- & -- \\
\hline DP & -- & -- & -- & .22 & .78 & 1.10 \\
\hline $\mathrm{CD}$ & - & -- & -- & .78 & .22 & 1.05 \\
\hline $\mathrm{CU}$ & 1.52 & .54 & 1.16 & - & - & -- \\
\hline PB & 886,692 & -1.69 & 1.18 & - & -- & - \\
\hline $\mathrm{ZN}$ & -- & - & - & .25 & .75 & 1.08 \\
\hline
\end{tabular}

${ }^{1}$ Form of equation is $\mathrm{y}=\mathrm{BO} \times \mathbf{R E G} \mathrm{B}^{\mathrm{B}} \mathrm{BCF}$.

${ }^{2}$ Form of equation is $y=\left(R E^{j}\right)(L O C)^{(1-j)} B C F$. 


\section{ESTIMATES OF A MEAN LOAD FOR A STORM}

In addition to developing single-storm regionalregression models for storm-runoff loads, volume, and event-mean concentrations, Driver and Tasker (1990) developed regression models for estimating the mean load for a storm, hereafter called mean load. Mean load is the estimate of mean load for a particular drainage basin. With the estimate of mean load, seasonal or annual loads for a particular drainage basin can be estimated by multiplying the mean load by the average number of storms for the season or year. Regression models for estimating mean load were based on drainage-basin area, percent of impervious area, mean annual rainfall, mean minimum January temperature, and a variable (dummy variable) indicating whether commercial and industrial land uses exceeded or did not exceed 75 percent of the drainage-basin area (Driver and Tasker, 1990). Regression models for estimating mean load were developed for COD, DS, SS, $\mathrm{TN}, \mathrm{TKN}, \mathrm{TP}, \mathrm{DP}, \mathrm{CU}, \mathrm{PB}$, and $\mathrm{ZN}$. These regression models were developed from the NURP data base and are based on rain storms. The range of explanatory variables used in the regression models for estimating mean load are listed in table 13. In general, use of the models to estimate mean load at sites that have characteristics much beyond the range of values listed in table 13 need to be avoided (Driver and Tasker, 1990). Using the Driver and Tasker (1990) models, mean loads were estimated for COD, DS, SS, TN, TKN, TP, DP, CU, PB, and ZN for sites 1 through 5. A 90-percent confidence interval was computed for each mean load of a storm estimated using the models from Driver and Tasker (1990) (table 14). For example, there is a 90-percent confidence level that the true mean load for TP for all storms at site 1 lies between 0.06 and $0.87 \mathrm{lb}$ (table 14). Confidence intervals were not computed for single-storm regression models because matrix information was unavailable.

Estimated mean loads from the Driver and Tasker (1990) models (MLDT) were compared to mean loads estimated for 1992, based on daily mean water discharge and land-use characteristics, hereafter referred to as MLDWD, and on loads that are the mean storm-runoff load of the six storms sampled at each of the five sites in 1992 (table 14).

Linear regression was used for estimating mean loads based on daily mean water discharge. The most suitable regression models for estimating mean load from daily mean water discharge were selected using the procedures described in the section "Single-Storm Local-Regression Models." Values of $r^{2}$ ranged from 0.59 to 0.84 , and standard error of estimate, in percent, for the regression models, ranged from 45 to 93 (table 15).

Table 13. Ranges of values of explanatory variables used in development of regression models for mean load for a storm (modified from Driver and Tasker, 1990)

[DA, total contributing drainage area; IA, impervious area; MAR, mean annual rainfall; MJT, mean minimum January temperature; COD, chemical oxygen demand; DS, dissolved solids; SS, suspended solids; TN, total nitrogen; TKN, total ammonia plus organic nitrogen as nitrogen; TP, total phosphorus; DP, dissolved phosphorus; $\mathrm{CU}$, total-recoverable copper; $\mathrm{PB}$, total-recoverable lead; $\mathrm{ZN}$, total-recoverable zinc]

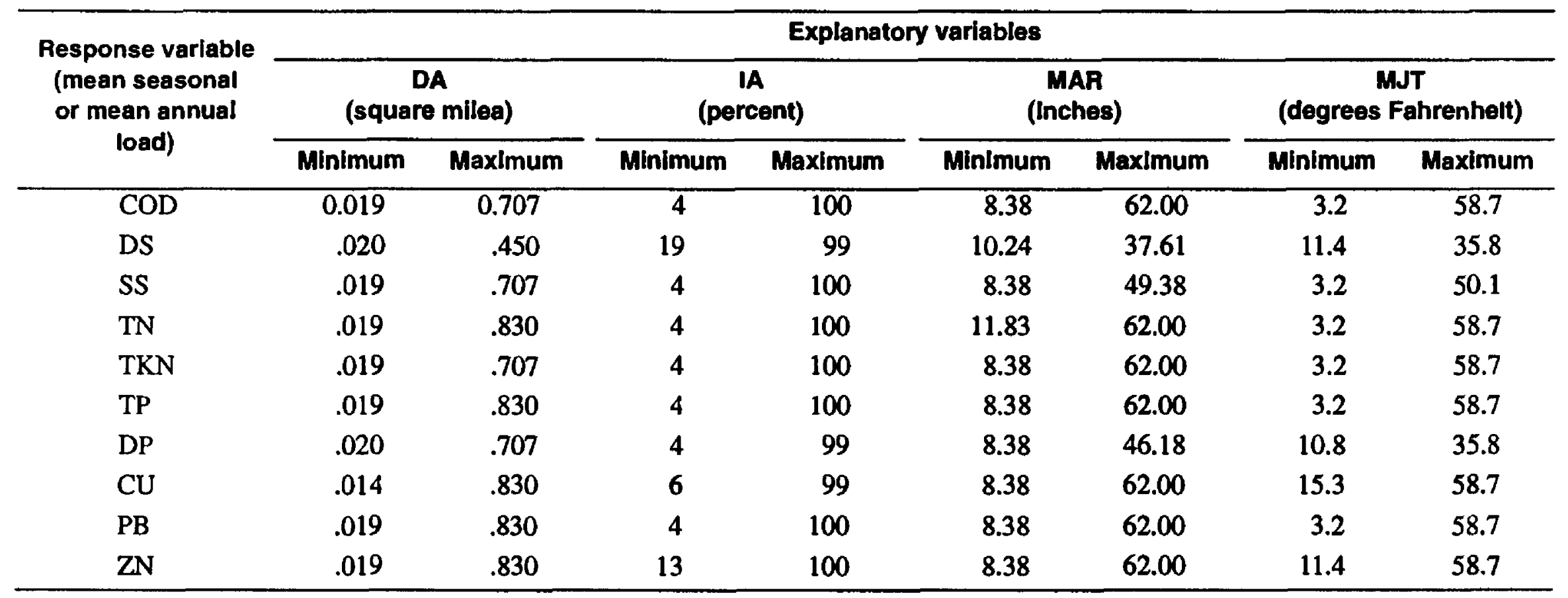


Table 14. Comparison of computed mean load for a storm based on daily mean water discharge and land-use characteristics, estimated mean load for a storm, and average of samples collected during rainfall runoff

[MLDWD, mean load estimated based on daily mean water discharge and land-use characteristics; MLDT, estimated mean load, from Driver and Tasker (1990) models; CI, 90-percent confidence interval; $n$, number of storms occurring as rain, January through December 1992; COD, chemical oxygen demand; DS, dissolved solids; SS, suspended solids; TN, total nitrogen; TKN, total ammonia plus organic nitrogen as nitrogen; TP, total phosphorus; DP, dissolved phosphorus; CU, total-recoverable copper, PB, total-recoverable lead; ZN, total-recoverable zinc]

\begin{tabular}{|c|c|c|c|c|c|}
\hline \multirow{3}{*}{$\begin{array}{l}\text { Response } \\
\text { varlable } \\
\text { (as load) }\end{array}$} & \multicolumn{4}{|c|}{$\begin{array}{l}\text { Mean load of a storm } \\
\text { (pounds) }\end{array}$} & \multirow{3}{*}{$\begin{array}{l}\text { Mean of six storms } \\
\text { In } 1992 \\
\text { (pounds) }\end{array}$} \\
\hline & \multirow{2}{*}{ MLDWD } & \multicolumn{3}{|c|}{$\begin{array}{l}\text { MLDT } \\
\text { Regression models in Drivar and Tasker (1990) }\end{array}$} & \\
\hline & & Estimated & Lower Cl & Uppar Cl & \\
\hline \multicolumn{6}{|c|}{$\begin{array}{l}\text { Sixteenth Hole, Valley-Hi Golf Conrse } \\
\text { Site } 1 \\
n=54\end{array}$} \\
\hline $\mathrm{COD}$ & 756 & 172 & 41 & 430 & 492 \\
\hline DS & 232 & 294 & 58 & 947 & 201 \\
\hline SS & 927 & 168 & 18.2 & 666 & 716 \\
\hline $\mathrm{TN}$ & 4.3 & 6.63 & 1.24 & 19.5 & 3.7 \\
\hline TKN & 2.4 & 2.16 & 0.43 & 6.68 & 2.3 \\
\hline PB & .54 & .28 & .05 & .84 & .27 \\
\hline $\mathrm{ZN}$ & .57 & .42 & .09 & 1.11 & .49 \\
\hline \multicolumn{6}{|c|}{$\begin{array}{l}\text { Chestnnt Street at Donglas Creek } \\
\qquad \begin{array}{c}\text { Site } 2 \\
n=48\end{array}\end{array}$} \\
\hline $\mathrm{COD}$ & 523 & 172 & 41 & 430 & 217 \\
\hline DS & 77 & 400 & 77 & 1,330 & 60 \\
\hline SS & 1,349 & 203 & 22.1 & 809 & 603 \\
\hline $\mathrm{TN}$ & 1.9 & 6.04 & 1.15 & 17.6 & 1.3 \\
\hline TKN & .90 & 1.94 & .38 & 6.11 & .76 \\
\hline \multicolumn{6}{|c|}{ 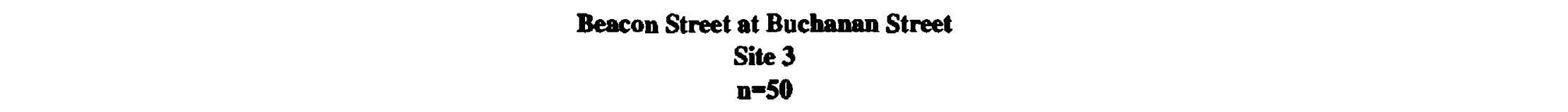 } \\
\hline COD & 312 & 223 & 53 & 560 & 92 \\
\hline DS & 71 & 424 & 81 & 1,410 & 37 \\
\hline SS & 433 & 210 & 22.9 & 837 & 107 \\
\hline $\mathrm{TN}$ & 2.0 & 2.9 & 0.49 & 9.7 & 1.2 \\
\hline TKN & 0.80 & 0.97 & .16 & 3.66 & 0.40 \\
\hline $\mathrm{TP}$ & .26 & .42 & .09 & 1.17 & .16 \\
\hline $\mathrm{DP}$ & .17 & .24 & .04 & .74 & .12 \\
\hline $\mathrm{CU}$ & .02 & .16 & .03 & .49 & .007 \\
\hline PB & .19 & .35 & .06 & 1.07 & .03 \\
\hline $\mathrm{ZN}$ & .24 & .55 & .12 & 1.43 & .12 \\
\hline
\end{tabular}


Table 14. Comparison of computed mean load for a storm based on daily mean water discharge and land-use characteristics, estimated mean load for a storm, and average of samples collected during rainfall runoff--Continued

\begin{tabular}{|c|c|c|c|c|c|}
\hline \multirow{3}{*}{$\begin{array}{l}\text { Response } \\
\text { variable } \\
\text { (as load) }\end{array}$} & \multicolumn{4}{|c|}{$\begin{array}{l}\text { Mean load of a atorm } \\
\text { (pounds) }\end{array}$} & \multirow{3}{*}{$\begin{array}{c}\text { Mean of six storms } \\
\text { In } 1992 \\
\text { (pounds) }\end{array}$} \\
\hline & \multirow{2}{*}{ MLDWD } & \multicolumn{3}{|c|}{$\begin{array}{l}\text { MLDT } \\
\text { Regression models In Drlver and Taeker (1990) }\end{array}$} & \\
\hline & & Estlmated & Lower Cl & Upper Cl & \\
\hline \multicolumn{6}{|c|}{$\begin{array}{c}\text { Wahsatch Street at Cross Lane } \\
\text { Site } 4 \\
n=50\end{array}$} \\
\hline COD & 465 & 357 & 83.3 & 906 & 378 \\
\hline DS & 117 & 1,060 & 173 & 4,140 & 140 \\
\hline SS & 929 & 372 & 39.7 & 1,510 & 747 \\
\hline TN & 4.7 & 10.8 & 2.01 & 31.9 & 5.2 \\
\hline TKN & .74 & 3.42 & .66 & 10.9 & .76 \\
\hline $\mathrm{TP}$ & 1.22 & .88 & .18 & 2.5 & 1.20 \\
\hline DP & .36 & .40 & .06 & 1.32 & .46 \\
\hline $\mathrm{CU}$ & .02 & .30 & .05 & .95 & .02 \\
\hline PB & .31 & .54 & .09 & 1.67 & .14 \\
\hline $\mathrm{ZN}$ & .31 & .80 & .17 & 2.13 & .31 \\
\hline \multicolumn{6}{|c|}{ 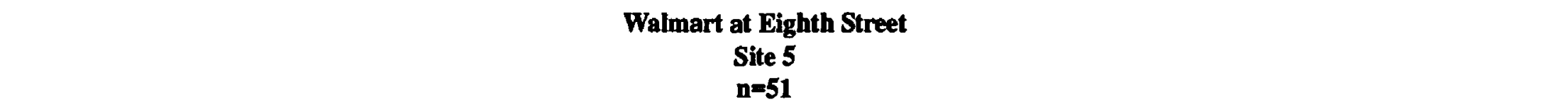 } \\
\hline COD & 339 & 76 & 18 & 190 & 58 \\
\hline DS & 45 & 136 & 27 & 432 & 26 \\
\hline SS & 407 & 103 & 11.1 & 416 & 237 \\
\hline $\mathrm{TN}$ & 0.89 & 3.12 & 0.58 & 9.22 & 0.64 \\
\hline TKN & .65 & 1.02 & .19 & 3.26 & .27 \\
\hline $\mathrm{TP}$ & .20 & .16 & .03 & 0.46 & .15 \\
\hline DP & .09 & .13 & .02 & .40 & .05 \\
\hline $\mathrm{CU}$ & .01 & .07 & .01 & .22 & .005 \\
\hline PB & .12 & .12 & .02 & .36 & .06 \\
\hline $\mathrm{ZN}$ & .20 & .17 & .04 & .45 & .11 \\
\hline
\end{tabular}

Table 15. Summary of $r^{2}$ values and standard error of estimate for regression models used to estimate mean load, in pounds, of a storm based on daily mean water discharge and land-use characteristics

$\left[r^{2}\right.$, is the coefficient of determination]

\begin{tabular}{|c|c|c|c|}
\hline \multirow{2}{*}{ Response varlable } & \multirow{2}{*}{$r^{2}$} & \multicolumn{2}{|c|}{ Standard error of estlmate } \\
\hline & & Percent & Log unlte \\
\hline Chemical oxygen demand & 0.75 & 57 & 0.229 \\
\hline Dissolved solids & .82 & 45 & .188 \\
\hline Suspended solids & .68 & 83 & .313 \\
\hline Total nitrogen & .81 & 47 & .195 \\
\hline Total ammonia plus organic nitrogen & .78 & 47 & .193 \\
\hline Total phosphorus & .75 & 66 & .262 \\
\hline Dissolved phosphorus & .59 & 81 & .308 \\
\hline Total-recoverable copper & .84 & 49 & .200 \\
\hline Total-recoverable lead & .65 & 93 & .344 \\
\hline Total-recoverable zinc & .81 & 55 & .225 \\
\hline
\end{tabular}


Records of daily mean water discharge were collected at all sites from about June 1 to December 6 , 1992. For periods of missing record, daily mean water discharge was estimated using the following equation:

$$
\begin{gathered}
\text { DMWD }=19,941 \mathrm{TRN}^{1.08} \mathrm{LUI}^{-1.26} \mathrm{LUC}^{-0.98} \\
\text { LUR }^{-1.78} 1.25
\end{gathered}
$$

where

$$
\begin{aligned}
\text { DMWD } & =\text { daily mean water discharge, in cubic feet } \\
& \text { per second; } \\
\text { TRN } & =\text { total rainfall, in inches; } \\
\text { LUI } & =\text { industrial land use, in percent; } \\
\text { LUC } & =\text { commercial land use, in percent; and } \\
\text { LUR } & =\text { residential land use in percent. }
\end{aligned}
$$

For this equation, the value of $\mathrm{r}^{2}$ was 0.77 , and the standard error of estimate was 78 percent.

Generally, MLDWD were within the 90-percent confidence intervals of MLDT (table 14). However, estimates of COD, DS, SS, and CU, at selected sites were not within the 90-percent confidence intervals from Driver and Tasker (1990) mean load equations. At sites 1,2, and 5, estimates of MLDWD for COD exceeded the upper 90-percent confidence interval (table 14); and at sites 1 and 2, MLDWD for SS exceeded the upper 90-percent confidence limit (table 14). At sites 3 and 4, estimates of MLDWD for DS and CU were less than the 90-percent confidence interval, and at site 2, estimates of mean load based on daily mean water discharge for $\mathrm{ZN}$ exceeded the upper 90-percent confidence interval (table 14).

At all sites, estimates of MLDWD for COD and SS were larger than MLDT (table 14). At all sites, estimates of MLDWD for DS, TN, and CU were less than MLDT (table 14). Estimates of MLDWD for TKN, TP, $\mathrm{DP}, \mathrm{PB}$, and $\mathrm{ZN}$ based on daily mean water discharge when compared to MLDT had no consistent direction of bias (table 14).

Differences between the two types of estimates of mean load may be explained by the following:

1. Hydrologic conditions controlling the occurrence of properties and constituents, especially COD and SS, that are specific to Colorado Springs are not accounted for in the Driver and Tasker (1990) models.

2. Data collected for certain properties and constituents for the NURP studies may not be representative of the Colorado Springs area.

Generally, the mean load of six storms at each site was within the 90-percent confidence interval of the Driver and Tasker (1990) mean load equations (table 14). The mean load of the six storms exceeded the upper 90-percent confidence interval for COD and SS at site 1 (table 14). The mean load of the six storms was less than the lower 90-percent confidence interval for DS at sites 2, 3, 4, and 5; for CU at sites 3, 4, and 5; and for PB at site 3 (table 14).

The mean load of the six storms at each site compared well with the estimates derived using the Driver and Tasker (1990) mean load equations. However, these mean loads represent only 6 storms, whereas the Driver and Tasker (1990) models were developed using between 200 and 1,000 storms that represent drainage basins having a wider range of drainage-basin area and percent impervious area (table 6). Therefore, the Driver and Tasker (1990) mean load equations might provide a better estimate of annual and seasonal loads for ungaged drainage basins in Colorado Springs.

\section{COMPARISON OF PROCEDURES FOR ESTIMATING STORM-RUNOFF LOADS, VOLUMES, EVENT-MEAN CONCENTRATIONS, AND THE MEAN LOAD FOR A STORM}

Various procedures for estimating storm-runoff loads, volume, and event-mean concentrations have been discussed in this report. The following is a more concise comparison of the value and limitations of these procedures. The procedures discussed include:

1. Single-storm local-regression models for stormrunoff loads, volume, and event-mean concentration (tables 4 and 5).

2. Single-storm regional-regression models for storm-runoff loads, volume, and event-mean concentration (Ellis and others, 1984; Driver and Tasker, 1990).

3. Adjustment of single-storm regional-regression models for storm-runoff loads, volume, and event-mean concentration using local data (tables 11 and 12) (Hoos and Sisolak, 1993).

4. Estimates of mean load (table 14).

The use of single-storm local-regression models needs to be limited to the ranges of explanatory variables (table 6) used to develop the model. If values outside these ranges are used in the single-storm localregression models, the standard errors may be considerably larger than the values reported in tables 4 and 5 . As the single-storm local-regression models are applied to drainage-basin areas and to storm volumes larger than the values from the observation sites, the accuracy of estimates of storm-runoff loads, volume, and event-mean concentrations decreases. 
Single-storm regional-regression models were developed using explanatory variables that have a wider range than the single-storm local-regression models (table 6). When compared to observed data, single-storm regional-regression models tended to overestimate storm-runoff loads, volumes, and eventmean concentrations (table 8). Model adjustment procedures (MAPs), which use local data to decrease the model error, were applied to selected single-storm regional-regression models. The MAPs decreased model error in estimating storm-runoff loads, volume, and event-mean concentrations-model error decreased from $-1,980$ to -10 percent (based on data in tables 9 and 10).

A prediction of annual or seasonal storm-runoff loads, volume, and event-mean concentration at an unmonitored site can be obtained by applying the single-storm models described to a series of storms and producing a synthetic record of storm loads and volume. Values of storm characteristics used as explanatory variables listed in table 6 and in Ellis and others (1984) and Driver and Tasker (1990) may be determined for a series of storms from the long-term rainfall record for a station near an unmonitored site. The synthesized record of storm loads may be reduced to an estimate of mean annual or mean seasonal load by summing loads from each storm, then dividing by the number of years in the period of the synthetic record.

The mean load estimated for individual sites for selected constituents generally compared well to mean load estimated based on daily mean water discharge and land-use characteristics and to the mean load of six storms, for each site, sampled in 1992 (table 14). The use of the mean load procedure should be limited to the range of values of variables used to develop the models (table 13). However, the mean load procedure can be applied to larger drainage basins by dividing the drainage basin into segments that fall into the range of drainage-basin areas used to develop the mean load model and computing the mean load for each drainage-basin segment. The mean load for the drainage basin would be the sum of the loads computed for each drainagebasin segment. Annual or seasonal loads could be computed by multiplying the estimated mean load by the average, or total for a specific year, number of storms for a drainage basin.

\section{SUMMARY}

The U.S. Environmental Protection Agency requires that municipalities that have a population of 100,000 or greater obtain National Pollutant Discharge Elimination System permits to control the quality of storm runoff. In 1992, the U.S. Geological Survey, in cooperation with the Colorado Springs City Engineer- ing Division, began a study to characterize the water quality of storm runoff and to compare techniques for the estimation of storm-runoff loads, volume, and event-mean concentrations for selected properties and constituents.

Precipitation, streamflow, and water-quality data were collected during 1992 at five sites in Colorado Springs. Thirty-five samples were collected, seven at each of the five sites. At each site, three samples were collected for National Pollutant Discharge Elimination System permitting purposes; two of the samples were collected during rainfall runoff, and one sample was collected during snowmelt runoff. Four additional samples were collected at each site to obtain a large enough sample size to estimate storm-runoff loads, volume, and event-mean concentrations for selected properties and constituents using linear-regression procedures developed using data from the Nationwide Urban Runoff Program (NURP). Storm-water samples were analyzed for as many as 186 properties and constituents. Some of the properties and constituents measured include $\mathrm{pH}$, specific conductance, water temperature, chemical oxygen demand, biochemical oxygen demand, bacteria, dissolved and suspended solids, major ions, nutrients, residual chlorine, totalrecoverable metals, oil and grease, phenols, volatileorganic compounds, acid-base/neutral organic compounds and pesticides.

Storm runoff sampled had large concentrations of chemical oxygen demand and 5-day biochemical oxygen demand. Chemical oxygen demand ranged from 100 to $830 \mathrm{mg} / \mathrm{L}$, and 5-day biochemical oxygen demand ranged from 14 to $260 \mathrm{mg} / \mathrm{L}$. Total-organic carbon concentrations ranged from 18 to $240 \mathrm{mg} / \mathrm{L}$. The total-recoverable metals lead and zinc had the largest concentrations of the total-recoverable metals analyzed. Concentrations of lead ranged from 23 to $350 \mu \mathrm{g} / \mathrm{L}$, and concentrations of zinc ranged from 110 to $1,400 \mu \mathrm{g} / \mathrm{L}$.

Single-storm local-regression models for estimating storm-runoff loads, volume, and event-mean concentrations were developed. Results from these models and observed values for storm-runoff loads, volume, and event-mean concentrations are compared with the results from regional-regression models developed from the Nationwide Urban Runoff Program for the purposes of determining which regression models provide the best estimates of storm-runoff loads, volume, and event-mean concentrations.

Single-storm local-regression models were developed for estimating storm-runoff loads and eventmean concentrations for the 12 National Pollutant Discharge Elimination System properties and constituents and for estimating storm-runoff volume. The data for 
30 storms representing rainfall runoff from 5 drainage basins were used in this analysis. Except for totalrecoverable cadmium, the models were developed using ordinary least-squares regression. Because some cadmium concentrations were censored (less than values), tobit regression, which is similar to ordinary leastsquares regression, was used to estimate storm-runoff load and event-mean concentration for total-recoverable cadmium. The response variables, which are storm-runoff loads, volume, and event-mean concentrations, were modeled using climatic, physical, and land-use characteristics.

The values of $\mathrm{r}^{2}$ for models that use ordinary least-squares regression ranged from 0.57 to 0.86 for storm-runoff loads and volume and from 0.25 to 0.63 for storm-runoff event-mean concentrations. Standard errors of estimate ranged from 43 to 115 percent for storm-runoff loads and volume and from 32 to 66 percent for storm-runoff event-mean concentrations. Standard errors of estimate for storm-runoff load and event-mean concentration for total-recoverable cadmium were 247 and 171 percent.

Single-storm linear-regression models for estimating storm-runoff loads, volume, and event-mean concentrations were developed for 11 of the 12 properties and constituents required for the National Pollutant Discharge Elimination System permitting process. Regional-regression equations for BOD were not developed. Linear-regression equations were developed from data collected by the NURP. Equations were developed from the NURP data base and include sets of equations for three geographically distinct regions delineated by mean annual rainfall. The Colorado Springs area is included in Region I. Estimates from these regression models were compared with observed storm-runoff loads, volume, and event-mean concentrations from samples collected in the study area.

Single-storm regional-regression models tended to overestimate storm-runoff loads, volume, and eventmean concentrations observed at the five Colorado Springs sites. Because regression models developed using local data are based on the climatic, physical, and land-use characteristics of the Colorado Springs area, single-storm local-regression models would be the preferred method for estimating storm-runoff loads, volume, and event-mean concentrations. As a result, single-storm local-regression models would be the preferred method for estimating storm-runoff loads, volume, and event-mean concentrations because the single-storm local-regression models were developed using local data based on the climatic, physical, and land-use characteristics of the Colorado Springs area. However, only a small number of observations (30) were available for the development of the single-storm local-regression models, and the use of the singlestorm local-regression models needs to be limited to estimations within the ranges of the explanatory variables used to develop the model. Although the singlestorm regional-regression models tended to overestimate storm-runoff loads, volume, and event-mean concentrations, these single-storm regional-regression models are based on a large number of observations (65 to 348), and the explanatory variables have a wider range than the explanatory variables used in the singlestorm local-regression models. Single-storm local- and regional-regression models were combined using model-adjustment procedures to take advantage of the strengths of both models while minimizing the respective deficiencies of the models.

When compared to observed storm-runoff loads and volume, the adjusted three-variable single-storm regional-regression models for storm-runoff loads and the multivariate regional-regression model for volume of runoff had the smallest root-mean-squared error of all of the single-storm regional-regression models tested. These models and the single-storm regionalregression models for event-mean concentration were adjusted using model-adjustment procedures.

Except for the equation for event-mean concentration of total-recoverable cadmium, all modeladjustment procedures decreased the error for models estimating storm-runoff loads, volume, and eventmean concentrations. Reduction of standard error, in percent, ranged from $-1,980$ to -10 percent.

In addition to developing single-storm regionalregression models for storm-runoff loads, volume, and event-mean concentrations, regression models for estimating mean load for a storm were developed for ten of the National Pollutant Discharge Elimination System properties and constituents. With the estimate of the mean load, seasonal or annual loads can be estimated by multiplying the mean load by the mean number of storms for the season or year. These regression models were developed from the NURP data base and are based on rain storms.

Mean loads were estimated for ten of the National Pollutant Discharge Elimination System properties and constituents for sites 1 through 5 . Estimated mean loads from the regional-regression equations were compared to mean loads estimated for 1992 , based on daily mean water discharge, and on loads that are the mean storm-runoff load of the six storms sampled at each of the five sites in 1992.

Except for selected estimates of chemical oxygen demand, dissolved solids, suspended solids, and total-recoverable copper, mean loads based on daily mean water discharge were within the 90-percent confidence interval of results from the mean load equa- 
tions. At sites 1,2, and 5, estimates of mean load based on daily mean water discharge for chemical oxygen demand, and at sites 1 and 2, estimates of mean load based on daily mean water discharge for suspended solids exceeded the upper 90 -percent confidence intervals. At sites 3 and 4, estimates of mean load based on daily mean water discharge for dissolved solids and totalrecoverable copper were less than the 90 -percent confidence interval.

At all sites, estimates of mean load based on daily mean water discharge for chemical oxygen demand and suspended solids were larger than mean loads estimated by the mean load equations. At all sites, estimates of mean load based on daily mean water discharge for dissolved solids, total nitrogen, and totalrecoverable copper were smaller than mean loads estimated by the equations. Estimates of mean load for total ammonia plus organic nitrogen as nitrogen, total phosphorus, dissolved phosphorus, total-recoverable lead, and total-recoverable zinc based on daily mean water discharge when compared to mean loads estimated by the mean load equations had no consistent direction of bias. Generally, the mean load of six storms was within the 90-percent confidence interval of the mean load equations. The mean load of the six storms for each site exceeded the upper 90-percent confidence interval for chemical oxygen demand and suspended solids at site 1 . The mean load of the six storms was less than the lower 90-percent confidence interval for dissolved solids at sites $2,3,4$, and 5; for totalrecoverable copper at sites 3,4 , and 5; and for totalrecoverable lead at site 3 .

The mean load of the six storms at each site compared well with the estimates derived using the mean load equations. However, these mean loads represent only 6 storms, whereas the equations were developed using between 200 and 1,000 storms that represent drainage basins having a wider range of drainage-basin area and percent impervious area. Therefore, the mean load equations might provide a better estimate of mean loads, and hence annual and seasonal load, for ungaged drainage basins in Colorado Springs.

\section{REFERENCES CITED}

Chow, Ven Te, 1964, Handbook of applied hydrology; a compendium of water-resources technology: New York, McGraw-Hill, variously paged.

Driver, N.E., and Tasker, G.D., 1990, Techniques for estimation of storm-runoff loads, volumes, and selected constituent concentrations in urban watersheds in the United States: U.S. Geological Survey Water-Supply Paper 2363, 44 p.
Duan, Naihua, 1983, Smearing estimate-A nonparametric retransformation method: Journal of the American Statistical Association, v. 78, no. 383, p. 605-610.

Ellis, S.R., Doerfer, J.T., Mustard, M.H., Blakely, S.R., and Gibbs, J.W., 1984, Analysis of urban storm-runoff data and the effects on the South Platte River, Denver metropolitan area, Colorado: U.S. Geological Survey Water-Resources Investigations Report 84-4159, 66 p.

Hansen, W.R., Chronic, John, and Matelock, John, 1978, Climatography of the Front Range urban corridor and vicinity, Colorado (reprint 1979): U.S. Geological Survey Professional Paper 1019, 59 p. (Reprinted in 1979)

Helsel, D.R., and Hirsch, R.M., 1992, Statistical methods in water resources: New York, Elsevier, 522 p.

Hoos, A.B., 1991, Storm-runoff quality and its relation to land use in the Nashville metropolitan area, Tennessee, in Jennings, M.E., ed., Symposium proceedings on urban hydrology: Bethesda, Md., American Water Resources Association, Technical Publication Series, TPS-91-4, p. 33.

Hoos, A.B., and Sisolak, J.K., 1993, Procedures for adjusting regional-regression models of urban-runoff quality using local data: U.S. Geological Survey Open-File Report 93-39, 39 p.

Iman, R.L., and Conover, W.J., 1983, A modern approach to statistics: New York, John Wiley, 497 p.

Kilpatrick, F.A., Kaehrle, W.R., Hardee, Jack, Cordes, E.H., and Landers, M.N., 1985, Development and testing of highway storm-sewer flow measurement and recording system: U.S. Geological Survey Water-Resources Investigations Report 85-4111, 98 p.

Statistical Analysis System Institute, Inc., 1990, SAS/STAT user's guide-Statistics (Version 6, 4th ed.): Cary, N.C., SAS Institute, Inc., 1661 p.

U.S. Environmental Protection Agency, 1990, National pollutant discharge elimination system permit, permit application regulations for storm water discharges; final rule: Federal Register, v. 55, no. 222, Code of Federal Regulations, title 40, v. 55, no. 222, parts 122, 123, 124, p. $47990-48091$.

U.S. Geological Survey, 1970, The national atlas of the United States of America, $335 \mathrm{p}$.

von Guerard, Paul, 1989, Suspended sediment and sedimentsource areas in the Fountain Creek drainage basin upstream from Widefield, southeastern Colorado: U.S. Geological Survey Water-Resources Investigations Report 88-4136, 36 p. 


\section{SUPPLEMENTAL DATA}


Table 16. Precipitation and runoff characteristics for samples collected at storm-runoff sites in Colorado Springs

$[-$, not available $]$

\begin{tabular}{|c|c|c|c|c|c|c|}
\hline Date & $\begin{array}{l}\text { Total } \\
\text { preclpltation } \\
\text { (inches) }\end{array}$ & $\begin{array}{c}\text { Runoff } \\
\text { (cublc feet) }\end{array}$ & $\begin{array}{l}\text { Duration of } \\
\text { runoff } \\
\text { (minutes) }\end{array}$ & $\begin{array}{l}\text { Peak fiow } \\
\text { (cublc feet } \\
\text { per second) }\end{array}$ & $\begin{array}{c}\text { Period that has less than } \\
0.10 \text { inch of precipltation } \\
\text { (days) }\end{array}$ & $\begin{array}{l}\text { Duration of } \\
\text { precipltatlon } \\
\text { (minutes) }\end{array}$ \\
\hline \multicolumn{7}{|c|}{384918104454201 - Sixteenth Hole, Valley-Hi Golf Conrse (Site 1) } \\
\hline $06-03-92$ & 0.21 & 46,100 & 155 & 37.1 & 2.0 & 110 \\
\hline $06-23-92$ & .07 & 26,800 & 170 & 8.57 & 2.0 & 101 \\
\hline $06-26-92$ & .13 & 14,900 & 125 & 16.8 & .5 & 50 \\
\hline $07-02-92$ & .08 & 16,400 & 240 & 7.19 & 3.0 & -- \\
\hline${ }^{1} 07-25-92$ & .33 & 78,500 & 325 & 22.3 & 9.0 & 127 \\
\hline${ }^{1} 08-10-92$ & .20 & 45,900 & 395 & 20.5 & 7.0 & 240 \\
\hline${ }^{1} 11-21-92$ & .78 & 34,600 & 560 & 2.99 & 8.0 & -- \\
\hline \multicolumn{7}{|c|}{ 385347104500601 - Chestnnt Street at Douglas Creek (Site 2) } \\
\hline${ }^{1} 05-31-92$ & .22 & 20,500 & 545 & 6.06 & 3.0 & 100 \\
\hline $06-05-92$ & .15 & 11,400 & 115 & 12.1 & 5.0 & 15 \\
\hline${ }^{1} 06-19-92$ & .29 & 16,400 & 395 & 15.2 & 14.0 & 118 \\
\hline $06-27-92$ & .10 & 8,330 & 70 & 8.11 & .5 & 25 \\
\hline $07-29-92$ & .23 & 23,200 & 195 & 20.5 & 5.0 & 10 \\
\hline $08-03-92$ & .08 & 7,920 & 115 & 4.92 & 5.0 & 39 \\
\hline${ }^{1} 11-21-92$ & .25 & 10,200 & 620 & 0.87 & 8.0 & -- \\
\hline \multicolumn{7}{|c|}{385240104493601 - Beacon Street at Bnchanan Street (Site 3) } \\
\hline${ }^{1} 06-05-92$ & .12 & 3,470 & 125 & 2.78 & 5.0 & 15 \\
\hline${ }^{1} 06-19-92$ & .29 & 15,800 & 355 & 4.92 & 8.0 & 115 \\
\hline $06-23-92$ & .14 & 5,770 & 210 & 1.24 & 4.0 & 120 \\
\hline $06-27-92$ & .08 & 3,960 & 205 & 2.59 & 2.0 & -- \\
\hline $08-02-92$ & .06 & 3,450 & 165 & 2.14 & 5.0 & 15 \\
\hline 08-03-92 & .14 & 7,030 & 265 & 3.72 & 1.0 & 13 \\
\hline${ }^{1} 11-11-92$ & .24 & 3,620 & 515 & 0.50 & 10.0 & -- \\
\hline \multicolumn{7}{|c|}{385118104485801 - Wahsatch Street at Cross Lane (Site 4) } \\
\hline $05-26-92$ & .30 & 10,400 & 195 & 3.19 & 1.0 & 120 \\
\hline $06-03-92$ & .25 & 9,400 & 160 & 10.2 & 3.0 & 15 \\
\hline${ }^{1} 06-12-92$ & .10 & 6,030 & 150 & 3.82 & 3.0 & 15 \\
\hline $06-26-92$ & .32 & 41,400 & 285 & 15.4 & 1.0 & 45 \\
\hline${ }^{1} 07-25-92$ & .41 & 48,900 & 285 & 13.9 & 8.5 & 95 \\
\hline $07-29-92$ & .19 & 22,600 & 175 & 13.9 & 4.0 & 10 \\
\hline${ }^{1} 11-21-92$ & .27 & 6,670 & 545 & 0.72 & 8.0 & -- \\
\hline \multicolumn{7}{|c|}{ 384935104501501 - Walmart at Eighth Street (Site 5) } \\
\hline $06-10-92$ & .10 & 6,890 & 115 & 8.58 & 1.0 & 10 \\
\hline $06-26-92$ & .05 & 1,560 & 60 & 2.87 & 3.0 & 35 \\
\hline${ }^{1} 07-17-92$ & .15 & 5,990 & 205 & 9.59 & 9.0 & 7 \\
\hline${ }^{1} 08-03-92$ & .10 & 2,990 & 70 & 5.35 & 6.0 & 20 \\
\hline $08-04-92$ & .05 & 1,440 & 70 & 1.92 & 0.8 & 35 \\
\hline $08-05-92$ & .17 & 6,400 & 105 & 5.09 & 1.1 & 35 \\
\hline${ }^{1} 12-06-92$ & .15 & 345 & 210 & 0.10 & 15.0 & -- \\
\hline
\end{tabular}

'Samples required for storm-water permit.

38 Water Quality of Storm Runoff and Comparison of Procedures for Estimating Storm-Runoff Loads, Volume, EventMean Concentrations, snd the Mean Load for a Storm for Selected Properties and Constituents for Colorado Springs, Southeastern Colorado, 1992 


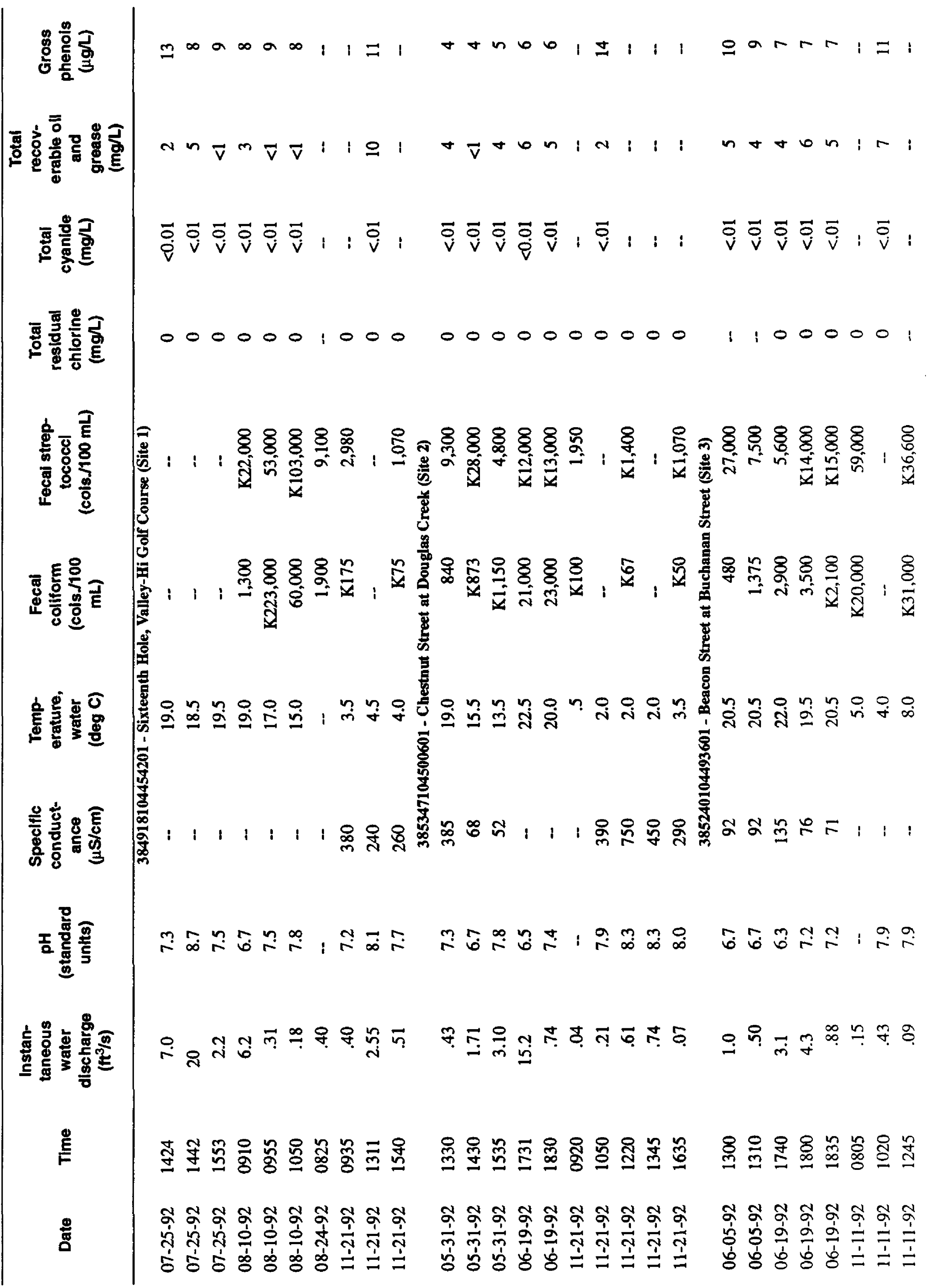




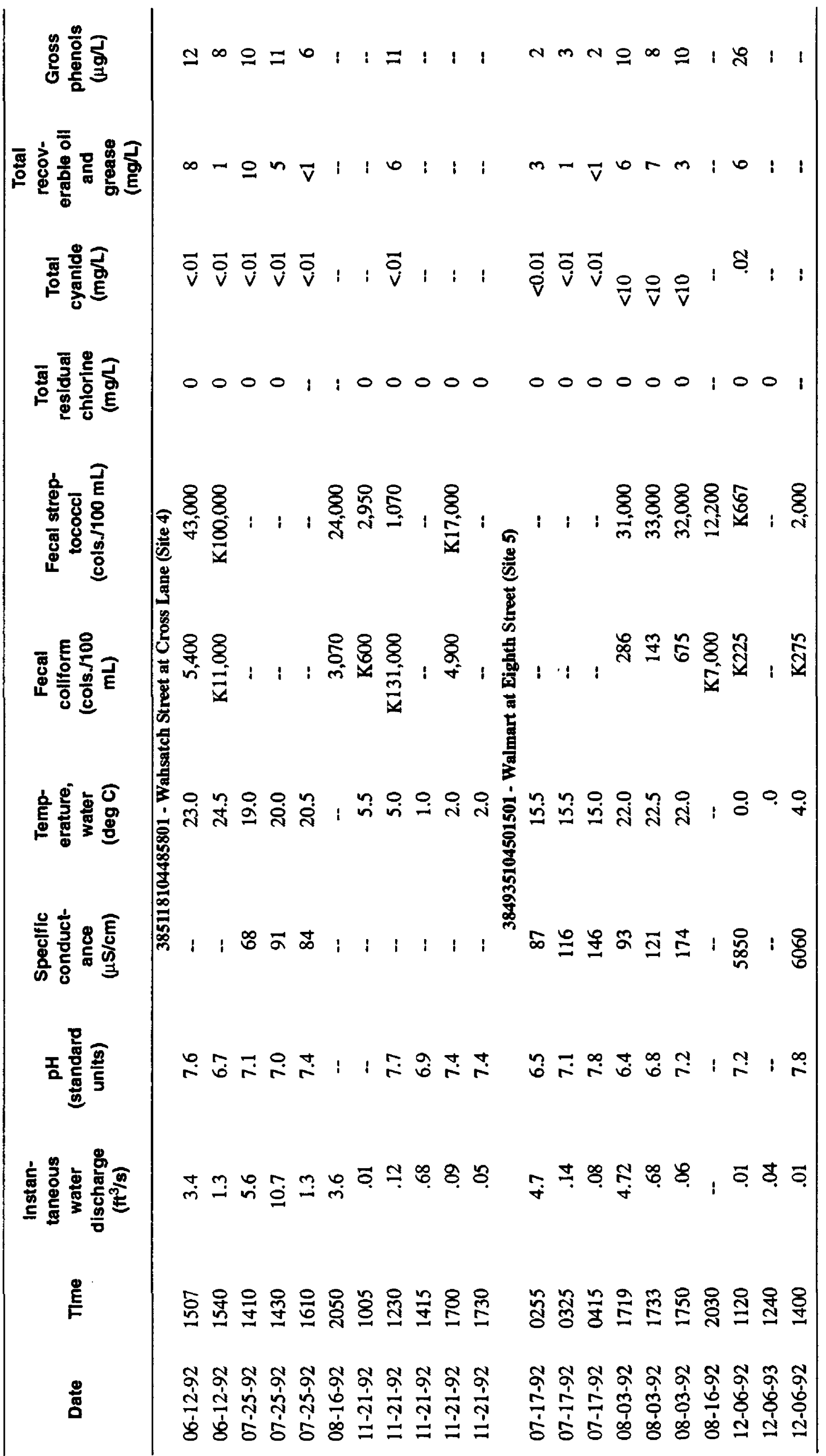


Table 18. Selected volatile-organic compounds for storm-runoff sites in Colorado Springs

[All constituents in micrograms per liter; $<$, less than]

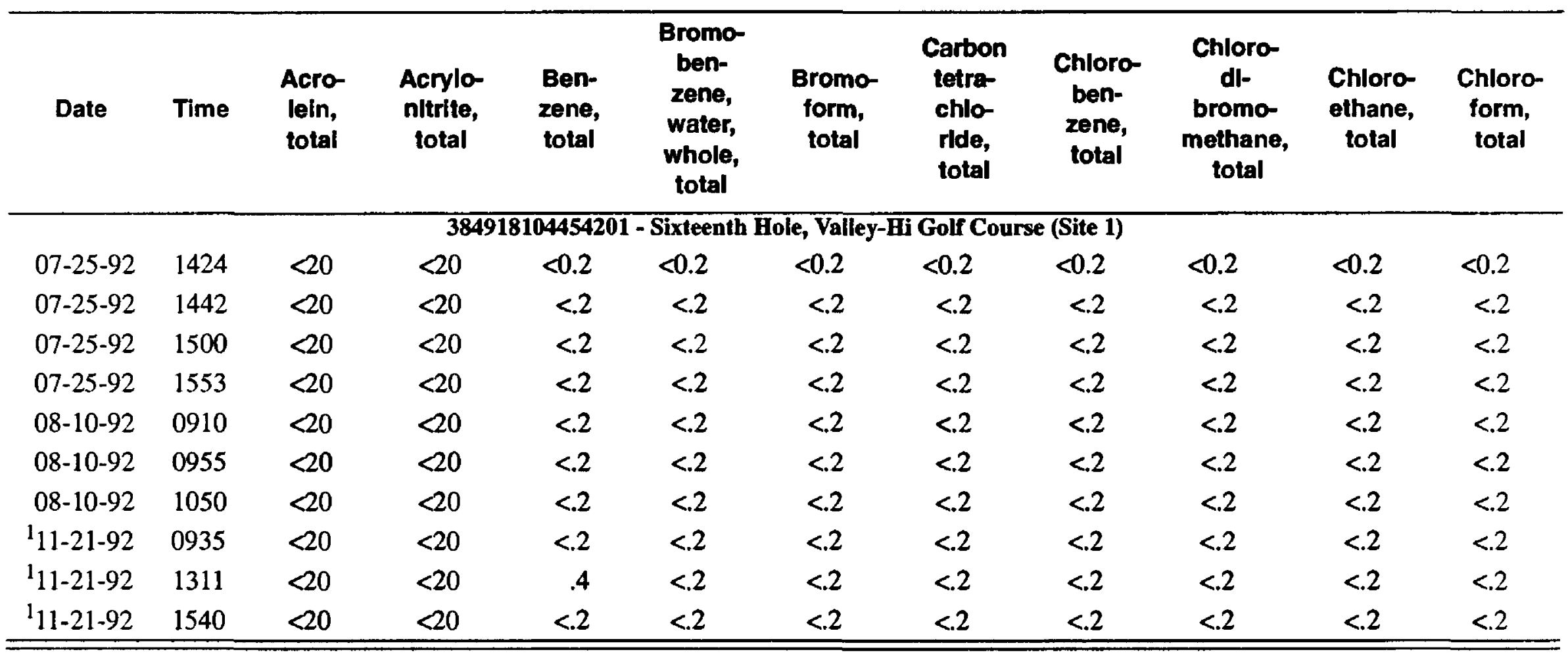

\begin{tabular}{|c|c|c|c|c|c|c|c|c|c|c|}
\hline Date & $\begin{array}{l}\text { Methyl- } \\
\text { chlo- } \\
\text { ride, } \\
\text { total }\end{array}$ & $\begin{array}{c}\text { Cls-1,2- } \\
\text { di- } \\
\text { chloro- } \\
\text { ethene, } \\
\text { water, } \\
\text { total }\end{array}$ & $\begin{array}{c}\text { Cls-1,3- } \\
\text { dl- } \\
\text { chloro- } \\
\text { pro- } \\
\text { pene, } \\
\text { total }\end{array}$ & $\begin{array}{c}\text { DI- } \\
\text { bromo- } \\
\text { chloro- } \\
\text { pro- } \\
\text { pene, } \\
\text { water, } \\
\text { whole, } \\
\text { total } \\
\text { recov- } \\
\text { erable }\end{array}$ & $\begin{array}{c}\text { Dl- } \\
\text { bromo- } \\
\text { methane, } \\
\text { water, } \\
\text { whole, } \\
\text { total } \\
\text { recov- } \\
\text { ereble }\end{array}$ & $\begin{array}{l}\text { Dl- } \\
\text { chloro- } \\
\text { bromo- } \\
\text { methene, } \\
\text { total }\end{array}$ & $\begin{array}{l}\text { Di-chloro- } \\
\text { dl-fluoro- } \\
\text { methane, } \\
\text { total }\end{array}$ & $\begin{array}{l}\text { Ethyl- } \\
\text { ben- } \\
\text { zene, } \\
\text { total }\end{array}$ & $\begin{array}{l}\text { Hexa- } \\
\text { chloro- } \\
\text { buta- } \\
\text { dlene, } \\
\text { total }\end{array}$ & $\begin{array}{l}\text { Iso- } \\
\text { propyl- } \\
\text { ben- } \\
\text { zene, } \\
\text { water, } \\
\text { whole, } \\
\text { recov- } \\
\text { erable }\end{array}$ \\
\hline $07-25-92$ & $<0.2$ & $<0.2$ & $<0.2$ & $<1.0$ & $<0.2$ & $<0.2$ & $<0.2$ & $<0.2$ & $<0.2$ & $<0.2$ \\
\hline $07-25-92$ & $<.2$ & $<.2$ & $<.2$ & $<1.0$ & $<.2$ & $<.2$ & $<.2$ & $<.2$ & $<.2$ & $<.2$ \\
\hline $07-25-92$ & $<.2$ & $<.2$ & $<2$ & $<1.0$ & $<.2$ & $<.2$ & $<.2$ & $<.2$ & $<2$ & $<2$ \\
\hline $07-25-92$ & $<.2$ & $<.2$ & $<.2$ & $<1.0$ & $<.2$ & $<.2$ & $<.2$ & $<.2$ & $<.2$ & $<.2$ \\
\hline $08-10-92$ & $<.2$ & $<.2$ & $<.2$ & $<1.0$ & $<.2$ & $<.2$ & $<.2$ & $<.2$ & $<.2$ & $<.2$ \\
\hline $08-10-92$ & $<.2$ & $<.2$ & $<.2$ & $<1.0$ & $<.2$ & $<.2$ & $<.2$ & $<.2$ & $<.2$ & $<.2$ \\
\hline $08-10-92$ & $<.2$ & $<.2$ & $<.2$ & $<1.0$ & $<.2$ & $<.2$ & $<.2$ & $<.2$ & $<.2$ & $<.2$ \\
\hline${ }^{1} 11-21-92$ & $<.2$ & $<.2$ & $<.2$ & $<1.0$ & $<.2$ & $<.2$ & $<.2$ & $<.2$ & $<.2$ & $<.2$ \\
\hline${ }^{1} 11-21-92$ & $<.2$ & $<.2$ & $<.2$ & $<1.0$ & $<.2$ & $<.2$ & $<.2$ & .3 & $<.2$ & $<.2$ \\
\hline${ }^{1} 11-21-92$ & $<2$ & $<.2$ & $<.2$ & $<1.0$ & $<.2$ & $<.2$ & $<.2$ & $<.2$ & $<.2$ & $<.2$ \\
\hline
\end{tabular}


Table 18. Selected volatile organic compounds for storm-runoff sites in Colorado Springs--Continued

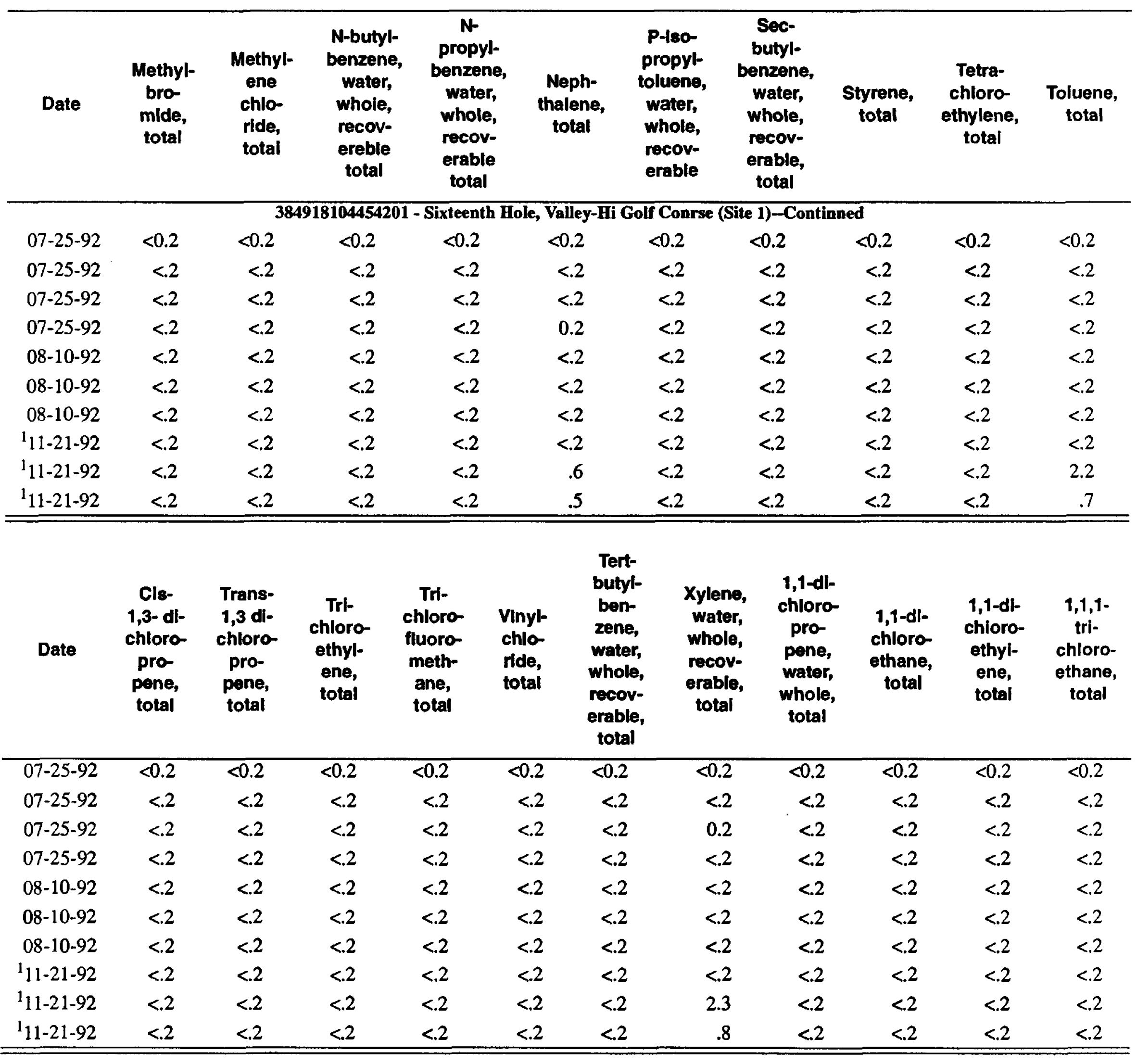

42 Water Quality of Storm Runoff and Comparison of Procedures for Estimating Storm-Runoff Loads, Volume, EventMean Concentrations, end the Mean Load for a Storm for Selected Propertiea and Constituents for Colorado Springs, Southeastern Colorado, 1992 
Tabie 18. Selected volatile organic compounds for storm-runoff sites in Colorado Springs--Continued

\begin{tabular}{|c|c|c|c|c|c|c|c|c|c|c|}
\hline Date & $\begin{array}{c}1,1,1,2- \\
\text { tetra- } \\
\text { chloro- } \\
\text { ethane, } \\
\text { water, } \\
\text { whole, } \\
\text { total }\end{array}$ & $\begin{array}{l}\text { 1,1,2-trl- } \\
\text { chloro- } \\
\text { ethane, } \\
\text { total }\end{array}$ & $\begin{array}{l}1,1,2,2- \\
\text { tetre- } \\
\text { chloro- } \\
\text { ethane, } \\
\text { total }\end{array}$ & $\begin{array}{c}\text { 1,2-dl- } \\
\text { bromo- } \\
\text { ethane, } \\
\text { water, } \\
\text { whole, } \\
\text { total }\end{array}$ & $\begin{array}{c}\text { 0-chloro- } \\
\text { benzene, } \\
\text { 1,2-dl- } \\
\text { chloro- } \\
\text { benzene, } \\
\text { total }\end{array}$ & $\begin{array}{l}\text { 1,2-dl- } \\
\text { chloro- } \\
\text { ethane, } \\
\text { total }\end{array}$ & $\begin{array}{c}\text { 1,2-dl- } \\
\text { chioro- } \\
\text { propane, } \\
\text { total }\end{array}$ & $\begin{array}{c}\text { O-chloro- } \\
\text { toluene, } \\
\text { water, } \\
\text { whole, } \\
\text { total }\end{array}$ & $\begin{array}{l}\text { 1,2-trans- } \\
\text { dl-chloro- } \\
\text { ethylene, } \\
\text { total }\end{array}$ & $\begin{array}{c}\text { 1, 2, 3- } \\
\text { tri- } \\
\text { chloro- } \\
\text { benzene, } \\
\text { water, } \\
\text { whole } \\
\text { recov- } \\
\text { erable } \\
\text { total }\end{array}$ \\
\hline \multicolumn{11}{|c|}{384918104454201 - Sixteenth Hole, Valley-Hi Golf Course (Site 1)-Continned } \\
\hline $07-25-92$ & $<0.2$ & $<0.2$ & $<0.2$ & $<0.2$ & $<0.2$ & $<0.2$ & $<0.2$ & $<0.2$ & $<0.2$ & $<0.2$ \\
\hline $07-25-92$ & $<.2$ & $<.2$ & $<.2$ & $<.2$ & $<.2$ & $<.2$ & $<.2$ & $<.2$ & $<.2$ & $<2$ \\
\hline $07-25-92$ & $<.2$ & $<.2$ & $<.2$ & $<.2$ & $<.2$ & $<.2$ & $<.2$ & $<.2$ & $<.2$ & $<.2$ \\
\hline $07-25-92$ & $<.2$ & $<.2$ & $<.2$ & $<.2$ & $<.2$ & $<.2$ & $<.2$ & $<.2$ & $<.2$ & $<.2$ \\
\hline $08-10-92$ & $<.2$ & $<.2$ & $<.2$ & $<.2$ & $<.2$ & $<.2$ & $<.2$ & $<.2$ & $<.2$ & $<.2$ \\
\hline $08-10-92$ & $<.2$ & $<.2$ & $<.2$ & $<.2$ & $<.2$ & $<.2$ & $<.2$ & $<.2$ & $<.2$ & $<.2$ \\
\hline $08-10-92$ & $<.2$ & $<.2$ & $<.2$ & $<.2$ & $<.2$ & $<.2$ & $<.2$ & $<.2$ & $<.2$ & $<.2$ \\
\hline $1_{11-21-92}$ & $<.2$ & $<.2$ & $<.2$ & $<.2$ & $<.2$ & $<.2$ & $<.2$ & $<.2$ & $<.2$ & $<.2$ \\
\hline${ }^{1} 11-21-92$ & $<.2$ & $<.2$ & $<.2$ & $<.2$ & $<.2$ & $<.2$ & $<.2$ & $<.2$ & $<.2$ & $<.2$ \\
\hline${ }^{1} 11-21-92$ & $<.2$ & $<.2$ & $<.2$ & $<.2$ & $<.2$ & $<.2$ & $<2$ & $<.2$ & $<.2$ & $<.2$ \\
\hline Date & $\begin{array}{c}\text { 1,2,3-tri- } \\
\text { chloro- } \\
\text { propane, } \\
\text { water, } \\
\text { whole, } \\
\text { total }\end{array}$ & $\begin{array}{c}\text { 1,2,4-trl- } \\
\text { chloro- } \\
\text { benzene, } \\
\text { lotal }\end{array}$ & $\begin{array}{c}\text { 1,2,4-tri- } \\
\text { methyl- } \\
\text { benzene, } \\
\text { water, } \\
\text { whole, } \\
\text { recov- } \\
\text { erable, } \\
\text { total }\end{array}$ & $\begin{array}{c}\text { 1,3-di- } \\
\text { chloro- } \\
\text { benzene, } \\
\text { total }\end{array}$ & $\begin{array}{c}\text { 1,3-di- } \\
\text { chloro- } \\
\text { propane, } \\
\text { water, } \\
\text { whole, } \\
\text { total }\end{array}$ & $\begin{array}{c}\text { 1,3,5-trl- } \\
\text { methyl- } \\
\text { benzene, } \\
\text { water, } \\
\text { whole, } \\
\text { recov- } \\
\text { erable }\end{array}$ & $\begin{array}{c}\text { Para- } \\
\text { chloro- } \\
\text { toluene, } \\
\text { water, } \\
\text { whole, } \\
\text { total }\end{array}$ & $\begin{array}{c}\text { 1,4-dl- } \\
\text { chloro- } \\
\text { benzene, } \\
\text { total }\end{array}$ & $\begin{array}{l}2- \\
\text { chloro- } \\
\text { ethyl- } \\
\text { vinyl- } \\
\text { ether, } \\
\text { total }\end{array}$ & $\begin{array}{c}\text { 2,2-di- } \\
\text { chloro- } \\
\text { propane, } \\
\text { water, } \\
\text { whole, } \\
\text { total }\end{array}$ \\
\hline $07-25-92$ & $<0.2$ & $<0.2$ & $<0.2$ & $<0.2$ & $<0.2$ & $<0.2$ & $<0.2$ & $<0.2$ & $<1.0$ & $<0.2$ \\
\hline $07-25-92$ & $<.2$ & $<.2$ & $<.2$ & $<.2$ & $<.2$ & $<.2$ & $<.2$ & $<.2$ & $<1.0$ & $<.2$ \\
\hline $07-25-92$ & $<.2$ & $<.2$ & $<.2$ & $<.2$ & $<, 2$ & $<.2$ & $<.2$ & $<.2$ & $<1.0$ & $<.2$ \\
\hline $07-25-92$ & $<.2$ & $<.2$ & $<.2$ & $<.2$ & $<.2$ & $<.2$ & $<.2$ & $<.2$ & $<1.0$ & $<.2$ \\
\hline $08-10-92$ & $<.2$ & $<.2$ & $<.2$ & $<.2$ & $<.2$ & $<.2$ & $<.2$ & $<.2$ & $<1.0$ & $<.2$ \\
\hline $08-10-92$ & $<.2$ & $<.2$ & $<.2$ & $<.2$ & $<.2$ & $<.2$ & $<.2$ & $<.2$ & $<1.0$ & $<.2$ \\
\hline $08-10-92$ & $<.2$ & $<.2$ & $<.2$ & $<.2$ & $<.2$ & $<.2$ & $<.2$ & $<.2$ & $<1.0$ & $<.2$ \\
\hline${ }^{1} 11-21-92$ & $<.2$ & $<.2$ & $<.2$ & $<.2$ & $<.2$ & $<.2$ & $<.2$ & $<.2$ & $<1.0$ & $<.2$ \\
\hline${ }^{1} 11-21-92$ & $<.2$ & $<.2$ & .6 & $<.2$ & $<.2$ & .2 & $<.2$ & $<.2$ & $<1.0$ & $<.2$ \\
\hline${ }^{1} 11-21-92$ & $<.2$ & $<.2$ & .3 & $<.2$ & $<.2$ & $<.2$ & $<.2$ & $<.2$ & $<1.0$ & $<.2$ \\
\hline
\end{tabular}


Table 18. Selected volatile organic compounds for storm-runoff sites in Colorado Springs-Continued

\begin{tabular}{|c|c|c|c|c|c|c|c|c|c|c|}
\hline Date & $\begin{array}{l}\text { Ac } \\
\text { le } \\
\text { to }\end{array}$ & $\begin{array}{l}\text { Acrylo } \\
\text { nitrite } \\
\text { total }\end{array}$ & $\begin{array}{c}\text { Benzene, } \\
\text { total }\end{array}$ & $\begin{array}{c}\text { Bromo- } \\
\text { benzene, } \\
\text { weter, } \\
\text { whole, } \\
\text { total }\end{array}$ & $\begin{array}{l}\text { Bromo } \\
\text { torm, } \\
\text { total }\end{array}$ & $\begin{array}{c}\text { Carbon- } \\
\text { tetra- } \\
\text { chloride } \\
\text { total }\end{array}$ & $\begin{array}{c}\text { Chloro- } \\
\text { benzene, } \\
\text { total }\end{array}$ & $\begin{array}{l}\text { Chloro- } \\
\text { dl- } \\
\text { bromo- } \\
\text { methene, } \\
\text { total }\end{array}$ & $\begin{array}{c}\text { Chloro- } \\
\text { ethane, } \\
\text { total }\end{array}$ & $\begin{array}{c}\text { Chloro- } \\
\text { form, } \\
\text { total }\end{array}$ \\
\hline \multicolumn{11}{|c|}{ 385347104500601 - Chestnut Street at Douglas Creek (Site 2) } \\
\hline $05-31-92$ & 1330 & $<20$ & $<0.2$ & $<0.2$ & $<0.2$ & $<0.2$ & $<0.2$ & $<0.2$ & $<0.2$ & $<0.2$ \\
\hline $05-31-92$ & 1535 & $<20$ & $<.2$ & $<.2$ & $<.2$ & $<.2$ & $<.2$ & $<.2$ & $<.2$ & $<.2$ \\
\hline $06-19-92$ & 1731 & $<20$ & $<.2$ & $<.2$ & $<.2$ & $<.2$ & $<.2$ & $<.2$ & $<.2$ & $<.2$ \\
\hline $06-19-92$ & 1830 & $<20$ & $<.2$ & $<.2$ & $<.2$ & $<.2$ & $<.2$ & $<.2$ & $<.2$ & $<.2$ \\
\hline${ }^{1} 11-21-92$ & 1050 & $<20$ & $<.2$ & $<.2$ & $<.2$ & $<.2$ & $<.2$ & $<.2$ & $<.2$ & $<.2$ \\
\hline${ }^{1} 11-21-92$ & 1345 & $<20$ & $<.2$ & $<.2$ & $<.2$ & $<.2$ & $<.2$ & $<.2$ & $<.2$ & $<.2$ \\
\hline${ }^{1} 11-21-92$ & 1635 & $<20$ & $<.2$ & $<.2$ & $<.2$ & $<.2$ & $<.2$ & $<.2$ & $<.2$ & $<.2$ \\
\hline Date & $\begin{array}{l}\text { Methyi- } \\
\text { chloride, } \\
\text { total }\end{array}$ & $\begin{array}{l}\text { Cls-1,2- } \\
\text { di- } \\
\text { chloro- } \\
\text { ethene, } \\
\text { water, } \\
\text { total }\end{array}$ & $\begin{array}{c}\text { Cis,-1,3- } \\
\text { dl- } \\
\text { chloro- } \\
\text { propene, } \\
\text { total }\end{array}$ & $\begin{array}{l}\text { DI- } \\
\text { bromo- } \\
\text { chloro- } \\
\text { propane, } \\
\text { water, } \\
\text { whole, } \\
\text { total- } \\
\text { recov- } \\
\text { ereble }\end{array}$ & $\begin{array}{c}\text { Dl- } \\
\text { bromo- } \\
\text { methane, } \\
\text { water, } \\
\text { whole, } \\
\text { recov- } \\
\text { erable }\end{array}$ & $\begin{array}{c}\text { Di- } \\
\text { chloro- } \\
\text { bromo- } \\
\text { methane, } \\
\text { total }\end{array}$ & $\begin{array}{c}\text { Dl- } \\
\text { chloro- } \\
\text { dl- } \\
\text { fluoro- } \\
\text { methane, } \\
\text { total }\end{array}$ & $\begin{array}{l}\text { Ethyl- } \\
\text { benzene, } \\
\text { total }\end{array}$ & $\begin{array}{l}\text { Hexa- } \\
\text { chloro- } \\
\text { buta- } \\
\text { diene, } \\
\text { total }\end{array}$ & $\begin{array}{c}\text { Iso- } \\
\text { propyl- } \\
\text { benzene, } \\
\text { water, } \\
\text { whole, } \\
\text { recov- } \\
\text { erable }\end{array}$ \\
\hline $05-31-92$ & $<0.2$ & $<0.2$ & $<0.2$ & $<1.0$ & $<0.2$ & $<0.2$ & $<0.2$ & $<0.2$ & $<0.2$ & $<0.2$ \\
\hline $05-31-92$ & $<.2$ & $<.2$ & $<.2$ & $<1.0$ & $<.2$ & $<.2$ & $<.2$ & $<.2$ & $<.2$ & $<.2$ \\
\hline $06-19-92$ & $<.2$ & $<.2$ & $<.2$ & $<1.0$ & $<.2$ & $<.2$ & $<.2$ & $<.2$ & $<.2$ & $<.2$ \\
\hline $06-19-92$ & $<.2$ & $<.2$ & $<.2$ & $<1.0$ & $<.2$ & $<.2$ & $<.2$ & $<.2$ & $<.2$ & $<.2$ \\
\hline${ }^{1} 11-21-92$ & $<.2$ & $<.2$ & $<.2$ & $<1.0$ & $<.2$ & $<.2$ & $<.2$ & $<.2$ & $<.2$ & $<.2$ \\
\hline${ }^{\prime} 11-21-92$ & $<.2$ & $<.2$ & $<.2$ & $<1.0$ & $<.2$ & $<.2$ & $<.2$ & $<.2$ & $<.2$ & $<.2$ \\
\hline${ }^{1} 11-21-92$ & $<.2$ & $<.2$ & $<.2$ & $<1.0$ & $<.2$ & $<.2$ & $<.2$ & $<.2$ & $<.2$ & $<.2$ \\
\hline Date & $\begin{array}{l}\text { Methyl- } \\
\text { bromide, } \\
\text { total }\end{array}$ & $\begin{array}{c}\text { Methyl- } \\
\text { ene } \\
\text { chlorlde, } \\
\text { folal }\end{array}$ & $\begin{array}{c}\text { N-butyl- } \\
\text { benzene, } \\
\text { water, } \\
\text { whole, } \\
\text { recov- } \\
\text { erable }\end{array}$ & $\begin{array}{c}\text { N-propyl } \\
\text { benzene, } \\
\text { water, } \\
\text { whole, } \\
\text { recov- } \\
\text { erable }\end{array}$ & $\begin{array}{l}\text { Neph- } \\
\text { tha- } \\
\text { lene, } \\
\text { total }\end{array}$ & $\begin{array}{c}\text { P-iso- } \\
\text { propyl- } \\
\text { toluene, } \\
\text { water, } \\
\text { whole, } \\
\text { recov- } \\
\text { erable }\end{array}$ & $\begin{array}{c}\text { Sec- } \\
\text { butyl- } \\
\text { benzene, } \\
\text { water, } \\
\text { whole, } \\
\text { recov- } \\
\text { erable }\end{array}$ & $\begin{array}{c}\text { Styrene, } \\
\text { total }\end{array}$ & $\begin{array}{l}\text { Tetre- } \\
\text { chloro- } \\
\text { ethylene, } \\
\text { totai }\end{array}$ & $\begin{array}{c}\text { Toluene, } \\
\text { total }\end{array}$ \\
\hline $05-31-92$ & $<0.2$ & $<0.2$ & $<0.2$ & $<0.2$ & $<0.2$ & $<0.2$ & $<0.2$ & $<0.2$ & $<0.2$ & $<0.2$ \\
\hline $05-31-92$ & $<.2$ & $<.2$ & $<.2$ & $<.2$ & $<.2$ & $<.2$ & $<.2$ & $<.2$ & $<.2$ & $<.2$ \\
\hline $06-19-92$ & $<.2$ & $<.2$ & $<.2$ & $<.2$ & $<.2$ & $<.2$ & $<.2$ & $<.2$ & $<.2$ & .4 \\
\hline $06-19-92$ & $<.2$ & $<.2$ & $<.2$ & $<.2$ & $<.2$ & $<.2$ & $<.2$ & $<.2$ & $<.2$ & $<.2$ \\
\hline${ }^{1} 11-21-92$ & $<.2$ & $<.2$ & $<.2$ & $<.2$ & .4 & $<.2$ & $<.2$ & $<.2$ & $<.2$ & .2 \\
\hline${ }^{1} 11-21-92$ & $<.2$ & $<.2$ & $<.2$ & $<.2$ & .2 & $<.2$ & $<.2$ & $<.2$ & $<.2$ & $<.2$ \\
\hline${ }^{\mathrm{t}} 11-21-92$ & $<2$ & $<.2$ & $<.2$ & $<.2$ & .2 & $<.2$ & $<.2$ & $<.2$ & $<.2$ & .2 \\
\hline
\end{tabular}

44 Water Quality of Storm Runoff and Comparlson of Procedures for Estimating Storm-Runoff Loads, Voiume, EventMean Concentrations, and the Mean Load for a Siorm for Selected Propertles and Constltuents for Coiorado Springs, Southeestern Colorado, 1992 
Table 18. Selected volatile organic compounds for storm-runoff sites in Colorado Springs--Continued

\begin{tabular}{|c|c|c|c|c|c|c|c|c|c|c|c|}
\hline \multirow[t]{2}{*}{ Date } & \multirow[t]{2}{*}{$\begin{array}{c}\text { Cis-1,3- } \\
\text { di- } \\
\text { chloro- } \\
\text { pro- } \\
\text { pene, } \\
\text { total }\end{array}$} & $\begin{array}{c}\text { Trans- } \\
\text { 1,3-di- } \\
\text { chloro- } \\
\text { pro- } \\
\text { pane, } \\
\text { total }\end{array}$ & $\begin{array}{l}\text { Trj- } \\
\text { chloro- } \\
\text { ethyl- } \\
\text { ene, } \\
\text { total }\end{array}$ & $\begin{array}{c}\text { Tri- } \\
\text { chloro- } \\
\text { fluoro- } \\
\text { meth- } \\
\text { ane, } \\
\text { total }\end{array}$ & $\begin{array}{l}\text { Vinyl- } \\
\text { chio- } \\
\text { ride, } \\
\text { total }\end{array}$ & \multicolumn{2}{|c|}{$\begin{array}{c}\text { Tert- } \\
\text { butyl- } \\
\text { benzene, } \\
\text { water, } \\
\text { whole, } \\
\text { recov- } \\
\text { erable }\end{array}$} & $\begin{array}{c}\text { 1,1-di- } \\
\text { chloro- } \\
\text { pro- } \\
\text { pene, } \\
\text { water, } \\
\text { whole, } \\
\text { total }\end{array}$ & \multirow[t]{2}{*}{$\begin{array}{l}\text { 1,1-dl- } \\
\text { chloro- } \\
\text { ethyl- } \\
\text { ene, } \\
\text { total }\end{array}$} & \multirow[t]{2}{*}{$\begin{array}{l}\text { 1, 1-di- } \\
\text { chloro- } \\
\text { ethyl- } \\
\text { ene, } \\
\text { total }\end{array}$} & \multirow[t]{2}{*}{$\begin{array}{c}\text { 1,1,1- } \\
\text { tri- } \\
\text { chloro- } \\
\text { ethane, } \\
\text { total }\end{array}$} \\
\hline & & \multicolumn{7}{|c|}{ 385347104500601 - Chestnut Street at Donglas Creek (Site 2)-Continned } & & & \\
\hline $05-31-92$ & $<0.2$ & $<0.2$ & $<0.2$ & $<0.2$ & $<0.2$ & $<0.2$ & $<0$ & $2<0.2$ & $<0.2$ & $<0.2$ & $<0.2$ \\
\hline $05-31-92$ & $<.2$ & $<.2$ & $<.2$ & $<.2$ & $<.2$ & $<.2$ & $<$ & $<.2$ & $<.2$ & $<.2$ & $<.2$ \\
\hline $06-19-92$ & $<.2$ & $<.2$ & $<.2$ & $<.2$ & $<.2$ & $<.2$ & & $<.2$ & $<.2$ & $<.2$ & $<.2$ \\
\hline $06-19-92$ & $<.2$ & $<.2$ & $<.2$ & $<.2$ & $<.2$ & $<.2$ & $<$ & $<.2$ & $<.2$ & $<.2$ & $<.2$ \\
\hline${ }^{1} 11-21-92$ & $<.2$ & $<.2$ & $<.2$ & $<.2$ & $<.2$ & $<.2$ & . & $<.2$ & $<.2$ & $<.2$ & $<.2$ \\
\hline${ }^{1} 11-21-92$ & $<.2$ & $<.2$ & $<.2$ & $<.2$ & $<.2$ & $<.2$ & . & $<.2$ & $<.2$ & $<.2$ & $<.2$ \\
\hline${ }^{1} 11-21-92$ & $<.2$ & $<.2$ & $<.2$ & $<.2$ & $<.2$ & $<.2$ & . & $<.2$ & $<.2$ & $<.2$ & $<.2$ \\
\hline Dete & $\begin{array}{c}1,1,1,2 \\
\text { tetra- } \\
\text { chloro- } \\
\text { ethane, } \\
\text { woter, } \\
\text { whole, } \\
\text { totel }\end{array}$ & $\begin{array}{l}\text { 1,1,2-tri- } \\
\text { chloro- } \\
\text { ethane, } \\
\text { total }\end{array}$ & $\begin{array}{c}\text { 1,1,2,2- } \\
\text { tetra- } \\
\text { chloro- } \\
\text { ethane, } \\
\text { total }\end{array}$ & $\begin{array}{c}\text { 1,2-dl- } \\
\text { bromo- } \\
\text { ethane, } \\
\text { water, } \\
\text { whole, } \\
\text { total }\end{array}$ & $\begin{array}{r}\text { 1, } \\
\text { ch } \\
\text { ben }\end{array}$ & & $\begin{array}{l}\text { 1,2-dl- } \\
\text { chioro- } \\
\text { ethane, } \\
\text { total }\end{array}$ & $\begin{array}{c}\text { 1,2-dl- } \\
\text { chloro- } \\
\text { propane, } \\
\text { total }\end{array}$ & $\begin{array}{c}\text { O-chloro- } \\
\text { toluene, } \\
\text { water, } \\
\text { whole, } \\
\text { total }\end{array}$ & $\begin{array}{l}\text { 1,2-trans } \\
\text { dl-chloro- } \\
\text { ethylene, } \\
\text { total }\end{array}$ & $\begin{array}{c}\text { 1,2,3-tri- } \\
\text { chloro- } \\
\text { benzene, } \\
\text { water, } \\
\text { whole, } \\
\text { recov- } \\
\text { erable }\end{array}$ \\
\hline $05-31-92$ & $<0.2$ & $<0.2$ & $<0.2$ & $<0.2$ & & & $<0.2$ & $<0.2$ & $<0.2$ & $<0.2$ & $<0.2$ \\
\hline $05-31-92$ & $<.2$ & $<, 2$ & $<.2$ & $<.2$ & & & $<.2$ & $<2$ & $<.2$ & $<.2$ & $<.2$ \\
\hline $06-19-92$ & $<.2$ & $<.2$ & $<.2$ & $<.2$ & & & $<.2$ & $<.2$ & $<.2$ & $<.2$ & $<.2$ \\
\hline $06-19-92$ & $<.2$ & $<.2$ & $<.2$ & $<.2$ & & & $<.2$ & $<2$ & $<.2$ & $<.2$ & $<.2$ \\
\hline${ }^{1} 11-21-92$ & $<.2$ & $<.2$ & $<.2$ & $<.2$ & & & $<.2$ & $<.2$ & $<.2$ & $<.2$ & $<.2$ \\
\hline${ }^{1} 11-21-92$ & $<.2$ & $<.2$ & $<.2$ & $<.2$ & & & $<.2$ & $<.2$ & $<.2$ & $<.2$ & $<.2$ \\
\hline${ }^{1} 11-21-92$ & $<.2$ & $<.2$ & $<.2$ & $<.2$ & & & $<.2$ & $<.2$ & $<.2$ & $<.2$ & $<.2$ \\
\hline $05-31-92$ & $<0.2$ & $<0.2$ & $<0.2$ & $<0.2$ & & & $<0.2$ & $<0.2$ & $<0.2$ & $<1.0$ & $<0.2$ \\
\hline $05-31-92$ & $<.2$ & $<.2$ & $<.2$ & $<.2$ & & & $<.2$ & $<.2$ & $<.2$ & $<1.0$ & $<.2$ \\
\hline $06-19-92$ & $<.2$ & $<.2$ & $<.2$ & $<.2$ & & & $<.2$ & $<.2$ & $<.2$ & $<1.0$ & $<.2$ \\
\hline $06-19-92$ & $<.2$ & $<.2$ & $<.2$ & $<.2$ & & & $<.2$ & $<.2$ & $<.2$ & $<1.0$ & $<.2$ \\
\hline${ }^{1} 11-21-92$ & $<.2$ & $<.2$ & .4 & $<.2$ & & & $<.2$ & $<.2$ & $<.2$ & $<1.0$ & $<.2$ \\
\hline${ }^{1} 11-21-92$ & $<.2$ & $<.2$ & .2 & $<.2$ & & & $<.2$ & $<.2$ & $<.2$ & $<1.0$ & $<.2$ \\
\hline${ }^{1} 11-21-92$ & $<.2$ & $<.2$ & $<.2$ & $<.2$ & & & $<.2$ & $<.2$ & $<.2$ & $<1.0$ & $<.2$ \\
\hline
\end{tabular}


Table 18. Selected volatile organic compounds for storm-runoff sites in Colorado Springs--Continued

\begin{tabular}{|c|c|c|c|c|c|c|c|c|c|c|c|}
\hline Date & Time & $\begin{array}{l}\text { Acro- } \\
\text { leln, } \\
\text { total }\end{array}$ & $\begin{array}{l}\text { Acry- } \\
\text { lo- } \\
\text { nitrile, } \\
\text { total }\end{array}$ & $\begin{array}{l}\text { Ben- } \\
\text { zene, } \\
\text { total }\end{array}$ & $\begin{array}{c}\text { Bromo- } \\
\text { benzene, } \\
\text { water, } \\
\text { whole, } \\
\text { total }\end{array}$ & $\begin{array}{l}\text { Bromo- } \\
\text { form, } \\
\text { totai }\end{array}$ & $\begin{array}{l}\text { Carbon- } \\
\text { tetre- } \\
\text { chlo- } \\
\text { rlde, } \\
\text { total }\end{array}$ & $\begin{array}{c}\text { Chloro- } \\
\text { benzene, } \\
\text { total }\end{array}$ & $\begin{array}{l}\text { Chloro- } \\
\text { dl- } \\
\text { bromo- } \\
\text { methane, } \\
\text { total }\end{array}$ & $\begin{array}{l}\text { Chloro- } \\
\text { ethane, } \\
\text { total }\end{array}$ & $\begin{array}{l}\text { Chioro- } \\
\text { form, } \\
\text { total }\end{array}$ \\
\hline \multicolumn{12}{|c|}{385240104493601 - Beacon Street at Buchanan Street (Site 3) } \\
\hline $06-05-92$ & 1300 & $<20$ & $<20$ & $<0.2$ & $<0.2$ & $<0.2$ & $<0.2$ & $<0.2$ & $<0.2$ & $<0.2$ & $<0.2$ \\
\hline $06-05-92$ & 1310 & $<20$ & $<20$ & $<.2$ & $<.2$ & $<.2$ & $<.2$ & $<.2$ & $<.2$ & $<.2$ & $<.2$ \\
\hline $06-19-92$ & 1740 & $<20$ & $<20$ & $<.2$ & $<.2$ & $<.2$ & $<.2$ & $<.2$ & $<.2$ & $<.2$ & $<.2$ \\
\hline $06-19-92$ & 1800 & $<20$ & $<20$ & $<.2$ & $<.2$ & $<.2$ & $<.2$ & $<.2$ & $<.2$ & $<.2$ & $<.2$ \\
\hline $06-19-92$ & 1835 & $<20$ & $<20$ & $<.2$ & $<.2$ & $<.2$ & $<.2$ & $<.2$ & $<.2$ & $<.2$ & $<.2$ \\
\hline${ }^{1} 11-11-92$ & 0805 & $<20$ & $<20$ & $<.2$ & $<.2$ & $<.2$ & $<.2$ & $<.2$ & $<.2$ & $<.2$ & $<.2$ \\
\hline${ }^{1} 11-11-92$ & 1020 & $<20$ & $<20$ & $<.2$ & $<.2$ & $<.2$ & $<.2$ & $<.2$ & $<.2$ & $<.2$ & $<.2$ \\
\hline${ }^{\prime} 11-11-92$ & 1245 & $<20$ & $<20$ & $<.2$ & $<.2$ & $<.2$ & $<.2$ & $<.2$ & $<.2$ & $<.2$ & $<.2$ \\
\hline Date & $\begin{array}{l}\text { Methyl- } \\
\text { chlo- } \\
\text { ride, } \\
\text { total }\end{array}$ & $\begin{array}{c}\text { Cis-1,2- } \\
\text { di- } \\
\text { chloro- } \\
\text { ethene, } \\
\text { water, } \\
\text { total }\end{array}$ & & $\begin{array}{l}\text { Cls-1,3- } \\
\text { dl- } \\
\text { chloro- } \\
\text { pro- } \\
\text { pene, } \\
\text { total }\end{array}$ & $\begin{array}{c}\text { DI- } \\
\text { bromo- } \\
\text { chloro- } \\
\text { pro- } \\
\text { pane, } \\
\text { water, } \\
\text { whole, } \\
\text { total- } \\
\text { recov- } \\
\text { erable }\end{array}$ & $\begin{array}{c}\text { Dl- } \\
\text { bromo- } \\
\text { meth- } \\
\text { ane, } \\
\text { water, } \\
\text { whole, } \\
\text { rocov- } \\
\text { erable }\end{array}$ & $\begin{array}{l}\text { DI- } \\
\text { chloro- } \\
\text { bromo- } \\
\text { meth- } \\
\text { ane, } \\
\text { total }\end{array}$ & $\begin{array}{l}\text { Di- } \\
\text { chloro- } \\
\text { di- } \\
\text { fluoro- } \\
\text { meth- } \\
\text { ane, } \\
\text { total }\end{array}$ & $\begin{array}{l}\text { Ethyl- } \\
\text { ben- } \\
\text { zene, } \\
\text { total }\end{array}$ & $\begin{array}{l}\text { Hexa- } \\
\text { chloro- } \\
\text { buta- } \\
\text { dlene, } \\
\text { totai }\end{array}$ & $\begin{array}{c}\text { Iso- } \\
\text { propyi- } \\
\text { ben- } \\
\text { zene, } \\
\text { water, } \\
\text { whole } \\
\text { recov- } \\
\text { erable }\end{array}$ \\
\hline $06-05-92$ & $<0.2$ & $<0.2$ & & $<0.2$ & $<1.0$ & $<0.2$ & $<0.2$ & $<0.2$ & $<0.2$ & $<0.2$ & $<0.2$ \\
\hline $06-05-92$ & $<.2$ & $<.2$ & & $<.2$ & $<1.0$ & $<.2$ & $<.2$ & $<.2$ & $<.2$ & $<.2$ & $<.2$ \\
\hline $06-19-92$ & $<.2$ & $<.2$ & & $<.2$ & $<1.0$ & $<.2$ & $<.2$ & $<.2$ & $<.2$ & $<.2$ & $<.2$ \\
\hline $06-19-92$ & $<.2$ & $<.2$ & & $<.2$ & $<1.0$ & $<.2$ & $<.2$ & $<.2$ & $<.2$ & $<.2$ & $<.2$ \\
\hline $06-19-92$ & $<.2$ & $<.2$ & & $<.2$ & $<1.0$ & $<.2$ & $<.2$ & $<.2$ & $<.2$ & $<.2$ & $<.2$ \\
\hline${ }^{1} 11-11-92$ & $<.2$ & $<.2$ & & $<.2$ & $<1.0$ & $<.2$ & $<.2$ & $<.2$ & $<.2$ & $<.2$ & $<.2$ \\
\hline${ }^{1} 11-11-92$ & $<.2$ & $<.2$ & & $<.2$ & $<1.0$ & $<.2$ & $<.2$ & $<.2$ & $<.2$ & $<.2$ & $<.2$ \\
\hline${ }^{1} 11-11-92$ & $<.2$ & $<.2$ & & $<.2$ & $<1.0$ & $<.2$ & .2 & $<.2$ & $<.2$ & $<.2$ & $<.2$ \\
\hline Date & $\begin{array}{l}\text { Methyl- } \\
\text { bromide, } \\
\text { total }\end{array}$ & $\begin{array}{l}\text { Methy- } \\
\text { lene- } \\
\text { chlorlde, } \\
\text { total }\end{array}$ & & $\begin{array}{l}\text { N-butyl- } \\
\text { cenzene, } \\
\text { water, } \\
\text { whole, } \\
\text { recov- } \\
\text { erable }\end{array}$ & $\begin{array}{c}\mathrm{N}- \\
\text { propyl- } \\
\text { benzene, } \\
\text { water, } \\
\text { whole, } \\
\text { recov- } \\
\text { erable }\end{array}$ & $\begin{array}{l}\text { Naph- } \\
\text { thalene, } \\
\text { total }\end{array}$ & $\begin{array}{l}\text { P-lao- } \\
\text { propyl- } \\
\text { toluene, } \\
\text { water, } \\
\text { whole, } \\
\text { recov- } \\
\text { erable }\end{array}$ & $\begin{array}{c}\text { Sec- } \\
\text { butyl- } \\
\text { benzene, } \\
\text { water, } \\
\text { whole, } \\
\text { recov- } \\
\text { erable }\end{array}$ & $\begin{array}{l}\text { Styrene, } \\
\text { total }\end{array}$ & $\begin{array}{l}\text { Tetra- } \\
\text { chloro- } \\
\text { othylene, } \\
\text { total }\end{array}$ & $\begin{array}{l}\text { Toluene, } \\
\text { total }\end{array}$ \\
\hline $06-05-92$ & $<0.2$ & $<0.2$ & & $<0.2$ & $<0.2$ & 1.0 & $<0.2$ & $<0.2$ & $<0.2$ & $<0.2$ & $<0.2$ \\
\hline $06-05-92$ & $<.2$ & $<.2$ & & $<.2$ & $<2$ & 1.1 & $<.2$ & $<.2$ & $<.2$ & $<.2$ & $<.2$ \\
\hline $06-19-92$ & $<.2$ & $<.2$ & & $<.2$ & $<2$ & $<.2$ & $<.2$ & $<.2$ & $<.2$ & $<.2$ & $<.2$ \\
\hline $06-19-92$ & $<.2$ & $<.2$ & & $<.2$ & $<.2$ & .3 & $<.2$ & $<.2$ & $<.2$ & $<.2$ & $<.2$ \\
\hline $06-19-92$ & $<.2$ & $<.2$ & & $<.2$ & $<.2$ & .4 & $<.2$ & $<.2$ & $<.2$ & $<.2$ & $<.2$ \\
\hline${ }^{1} 11-11-92$ & $<.2$ & $<.2$ & & $<.2$ & $<.2$ & .6 & $<.2$ & $<.2$ & $<.2$ & $<.2$ & .2 \\
\hline${ }^{1} 11-11-92$ & $<.2$ & $<.2$ & & $<.2$ & $<.2$ & $<.2$ & $<.2$ & $<.2$ & $<.2$ & $<.2$ & $<.2$ \\
\hline${ }^{1} 11-11-92$ & $<.2$ & $<.2$ & & $<.2$ & $<.2$ & .3 & $<.2$ & $<.2$ & $<.2$ & $<.2$ & $<.2$ \\
\hline
\end{tabular}

46 Water Quality of Storm Runoff and Comparison of Procedures for Estimating Storm-Runoff Loads, Volume, EventMean Concentrations, and the Mean Load for a Storm for Selected Propertlea and Conatituents for Colorado Springs, Southeastern Colorado, 1992 
Tabie 18. Selected volatile organic compounds for storm-runoff sites in Colorado Springs--Continued

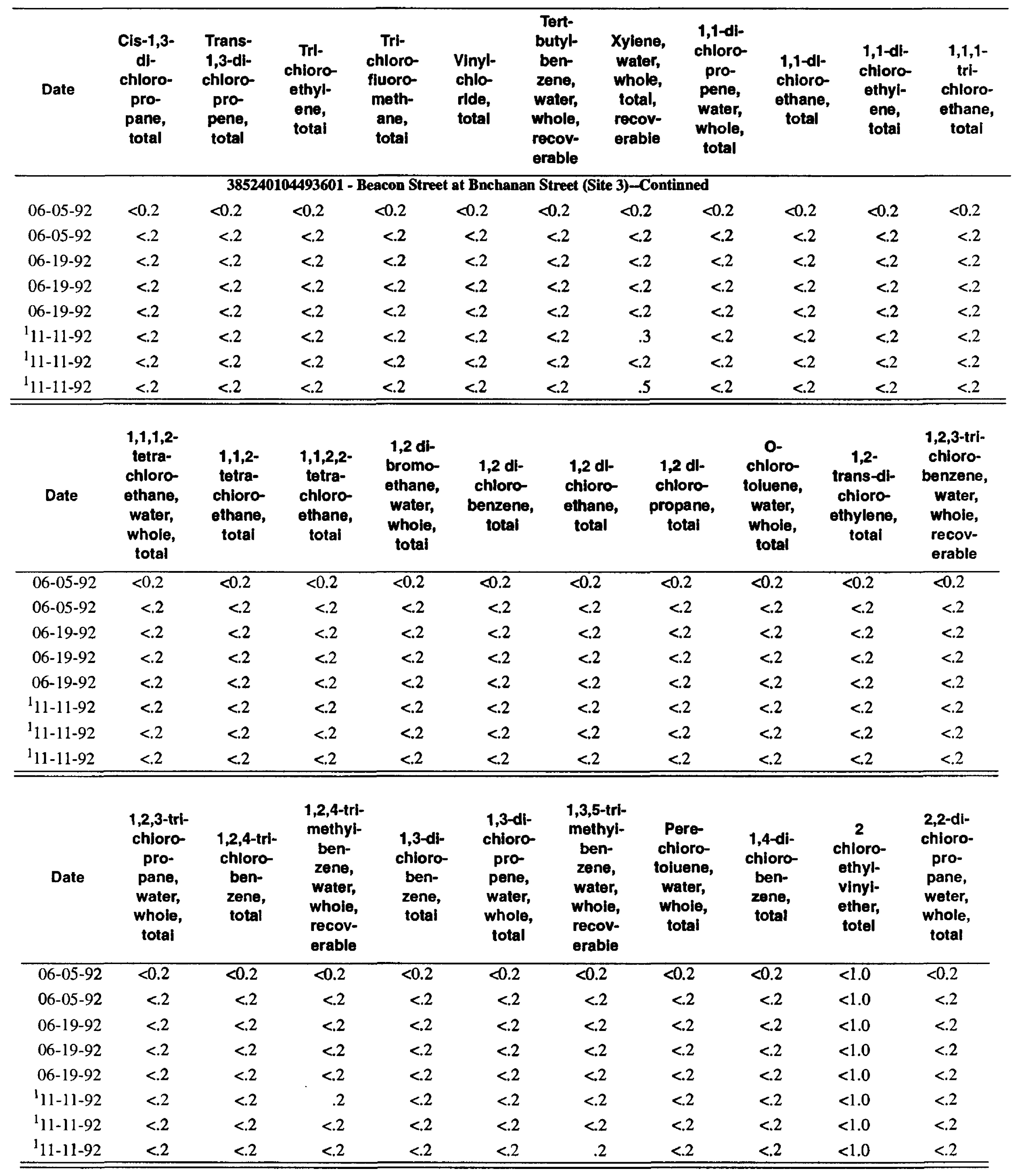


Table 18. Selected volatile organic compounds for storm-runoff sites in Colorado Springs--Continued

\begin{tabular}{|c|c|c|c|c|c|c|c|c|c|c|}
\hline Date & Time & $\begin{array}{l}\text { Acro- } \\
\text { leln, } \\
\text { total }\end{array}$ & $\begin{array}{l}\text { Acrylo- } \\
\text { nltrlle, } \\
\text { total }\end{array}$ & $\begin{array}{r}\text { Brom } \\
\text { ben } \\
\text { zen } \\
\text { wate } \\
\text { who } \\
\text { tots }\end{array}$ & $\begin{array}{c}\text { Bromo } \\
\text { form, } \\
\text { total }\end{array}$ & $\begin{array}{l}\text { Carbon- } \\
\text { tetra- } \\
\text { chlo- } \\
\text { ride, } \\
\text { total }\end{array}$ & $\begin{array}{c}\text { Chloro- } \\
\text { ben- } \\
\text { zene, } \\
\text { total }\end{array}$ & $\begin{array}{l}\text { Chloro- } \\
\text { dl- } \\
\text { bromo- } \\
\text { meth- } \\
\text { ane, } \\
\text { total }\end{array}$ & $\begin{array}{c}\text { Chloro- } \\
\text { ethane, } \\
\text { total }\end{array}$ & $\begin{array}{c}\text { Chloro- } \\
\text { form, } \\
\text { total }\end{array}$ \\
\hline \multicolumn{11}{|c|}{385118104485801 - Wahsatch Street at Cross Lane (Site 4) } \\
\hline $06-12-92$ & 1507 & $<20$ & $<20<$ & $<0.2<0.2$ & $<0.2$ & $<0.2$ & $<0.2$ & $<0.2$ & $<0.2$ & $<0.2$ \\
\hline $06-12-92$ & 1540 & $<20$ & $<20$ & $<.2$ & $<.2$ & $<.2$ & $<.2$ & $<.2$ & $<.2$ & $<.2$ \\
\hline $07-25-92$ & 1410 & $<20$ & $<20$ & $<.2$ & $<.2$ & $<.2$ & $<.2$ & $<.2$ & $<.2$ & $<.2$ \\
\hline $07-25-92$ & 1430 & $<20$ & $<20$ & $<.2$ & $<.2$ & $<.2$ & $<.2$ & $<.2$ & $<.2$ & $<.2$ \\
\hline $07-25-92$ & 1610 & $<20$ & $<20$ & $<.2$ & $<.2$ & $<.2$ & $<.2$ & $<.2$ & $<.2$ & $<.2$ \\
\hline${ }^{1} 11-21-92$ & 1230 & $<20$ & $<20$ & $<.2$ & $<.2$ & $<.2$ & $<.2$ & $<.2$ & $<.2$ & $<.2$ \\
\hline${ }^{1} 11-21-92$ & 1415 & $<20$ & $<20$ & .3 & $<.2$ & $<.2$ & $<.2$ & $<.2$ & $<.2$ & $<.2$ \\
\hline${ }^{1} 11-21-92$ & 1730 & $<20$ & $<20$ & $<.2$ & $<.2$ & $<.2$ & $<.2$ & $<.2$ & $<.2$ & $<.2$ \\
\hline Date & $\begin{array}{l}\text { Methyl- } \\
\text { chloride, } \\
\text { total }\end{array}$ & $\begin{array}{c}\text { Cis-1,2- } \\
\text { di- } \\
\text { chloro- } \\
\text { ethene, } \\
\text { water, } \\
\text { total }\end{array}$ & $\begin{array}{c}\text { Cls-1,3 } \\
\text { dl- } \\
\text { chloro- } \\
\text { propane, } \\
\text { total }\end{array}$ & $\begin{array}{c}\text { Dl- } \\
\text { bromo- } \\
\text { chloro- } \\
\text { propene, } \\
\text { water, } \\
\text { whole, } \\
\text { total } \\
\text { recov- } \\
\text { erable }\end{array}$ & $\begin{array}{c}\text { Di- } \\
\text { bromo- } \\
\text { meth- } \\
\text { ane, } \\
\text { water, } \\
\text { whole, } \\
\text { recov- } \\
\text { erable }\end{array}$ & $\begin{array}{l}\text { DI- } \\
\text { chloro- } \\
\text { bromo- } \\
\text { meth- } \\
\text { ane, } \\
\text { total }\end{array}$ & $\begin{array}{l}\text { DF- } \\
\text { chloro- } \\
\text { di- } \\
\text { fluoro- } \\
\text { moth- } \\
\text { ane, } \\
\text { total }\end{array}$ & $\begin{array}{l}\text { Ethyl- } \\
\text { ben- } \\
\text { zene, } \\
\text { total }\end{array}$ & $\begin{array}{l}\text { Hexa- } \\
\text { chloro- } \\
\text { buta- } \\
\text { diene, } \\
\text { total }\end{array}$ & $\begin{array}{c}\text { Iso- } \\
\text { propyl- } \\
\text { ben- } \\
\text { zene, } \\
\text { water, } \\
\text { whole, } \\
\text { recov- } \\
\text { ersble }\end{array}$ \\
\hline $06-12-92$ & $<0.2$ & $<0.2$ & $<0.2$ & $<1.0$ & $<0.2$ & $<0.2$ & $<0.2$ & 0.2 & $<0.2$ & $<0.2$ \\
\hline $06-12-92$ & $<.2$ & $<.2$ & $<.2$ & $<1.0$ & $<, 2$ & $<.2$ & $<.2$ & $<.2$ & $<.2$ & $<.2$ \\
\hline $07-25-92$ & $<.2$ & $<.2$ & $<.2$ & $<1.0$ & $<.2$ & $<.2$ & $<2$ & $<.2$ & $<.2$ & $<.2$ \\
\hline $07-25-92$ & $<.2$ & $<.2$ & $<2$ & $<1.0$ & $<2$ & $<.2$ & $<.2$ & $<.2$ & $<.2$ & $<2$ \\
\hline $07-25-92$ & $<.2$ & $<.2$ & $<2$ & $<1.0$ & $<.2$ & $<.2$ & $<2$ & $<.2$ & $<.2$ & $<.2$ \\
\hline${ }^{1} 11-21-92$ & $<.2$ & $<.2$ & $<2$ & $<1.0$ & $<.2$ & $<.2$ & $<.2$ & $<.2$ & $<.2$ & $<.2$ \\
\hline${ }^{1} 11-21-92$ & $<.2$ & $<.2$ & $<.2$ & $<1.0$ & $<.2$ & $<.2$ & $<.2$ & $<.2$ & $<.2$ & $<.2$ \\
\hline${ }^{1} 11-21-92$ & $<.2$ & $<.2$ & $<2$ & $<1,0$ & $<.2$ & $<.2$ & $<.2$ & $<.2$ & $<.2$ & $<.2$ \\
\hline Dste & $\begin{array}{l}\text { Methyl- } \\
\text { bro- } \\
\text { mide, } \\
\text { total }\end{array}$ & $\begin{array}{l}\text { Methyl- } \\
\text { ene- } \\
\text { chlo- } \\
\text { rlde, } \\
\text { total }\end{array}$ & $\begin{array}{c}\text { N-butyl- } \\
\text { ben- } \\
\text { zene, } \\
\text { water, } \\
\text { whole, } \\
\text { recov- } \\
\text { erable }\end{array}$ & $\begin{array}{c}\text { N- } \\
\text { propy- } \\
\text { ben- } \\
\text { zene, } \\
\text { water, } \\
\text { whole, } \\
\text { recov- } \\
\text { erable }\end{array}$ & $\begin{array}{c}\text { Naph- } \\
\text { thalene, } \\
\text { total }\end{array}$ & $\begin{array}{c}\text { P-lao- } \\
\text { propyl- } \\
\text { toluene, } \\
\text { water, } \\
\text { whole, } \\
\text { recov- } \\
\text { erable }\end{array}$ & $\begin{array}{c}\text { Sec- } \\
\text { butyl- } \\
\text { ben- } \\
\text { zene, } \\
\text { water, } \\
\text { whole, } \\
\text { recov- } \\
\text { erable }\end{array}$ & $\begin{array}{c}\text { Styrene, } \\
\text { total }\end{array}$ & $\begin{array}{l}\text { Tetra- } \\
\text { chloro- } \\
\text { ethyl- } \\
\text { ene, } \\
\text { total }\end{array}$ & $\begin{array}{c}\text { Toluene, } \\
\text { total }\end{array}$ \\
\hline $06-12-92$ & $<0.2$ & $<0.2$ & $<0.2$ & $<0.2$ & 0.3 & 0.2 & $<0.2$ & $<0.2$ & $<0.2$ & 0.5 \\
\hline $06-12-92$ & $<.2$ & $<.2$ & $<.2$ & $<.2$ & $<2$ & $<.2$ & $<.2$ & $<.2$ & $<.2$ & .6 \\
\hline $07-25-92$ & $<.2$ & $<.2$ & $<.2$ & $<.2$ & $<2$ & $<.2$ & $<.2$ & $<.2$ & $<.2$ & $<.2$ \\
\hline $07-25-92$ & $<.2$ & $<.2$ & $<.2$ & $<2$ & $<.2$ & $<.2$ & $<.2$ & $<.2$ & $<.2$ & .3 \\
\hline $07-25-92$ & $<.2$ & $<.2$ & $<.2$ & $<.2$ & $<.2$ & $<.2$ & $<.2$ & $<.2$ & $<.2$ & $<.2$ \\
\hline${ }^{1} 11-21-92$ & $<.2$ & $<.2$ & $<.2$ & $<.2$ & .2 & $<.2$ & $<.2$ & $<.2$ & $<.2$ & 1.2 \\
\hline${ }^{1} 11-21-92$ & $<.2$ & $<.2$ & $<.2$ & $<, 2$ & .3 & $<.2$ & $<.2$ & $<.2$ & $<.2$ & 1.1 \\
\hline${ }^{1} 11-21-92$ & $<.2$ & $<.2$ & $<.2$ & $<.2$ & .4 & $<.2$ & $<.2$ & $<.2$ & $<.2$ & .3 \\
\hline
\end{tabular}

48 Water Quality of Storm Aunoff and Comparlson of Procedures for Estimating Storm-Aunoff Loads, Volume, EventMean Concentratlons, and the Mean Load for a Storm for Selected Propertiea and Constituents for Colorado Sprlngs, 
Table 18. Selected volatile organic compounds for storm-runoff sites in Colorado Springs--Continued

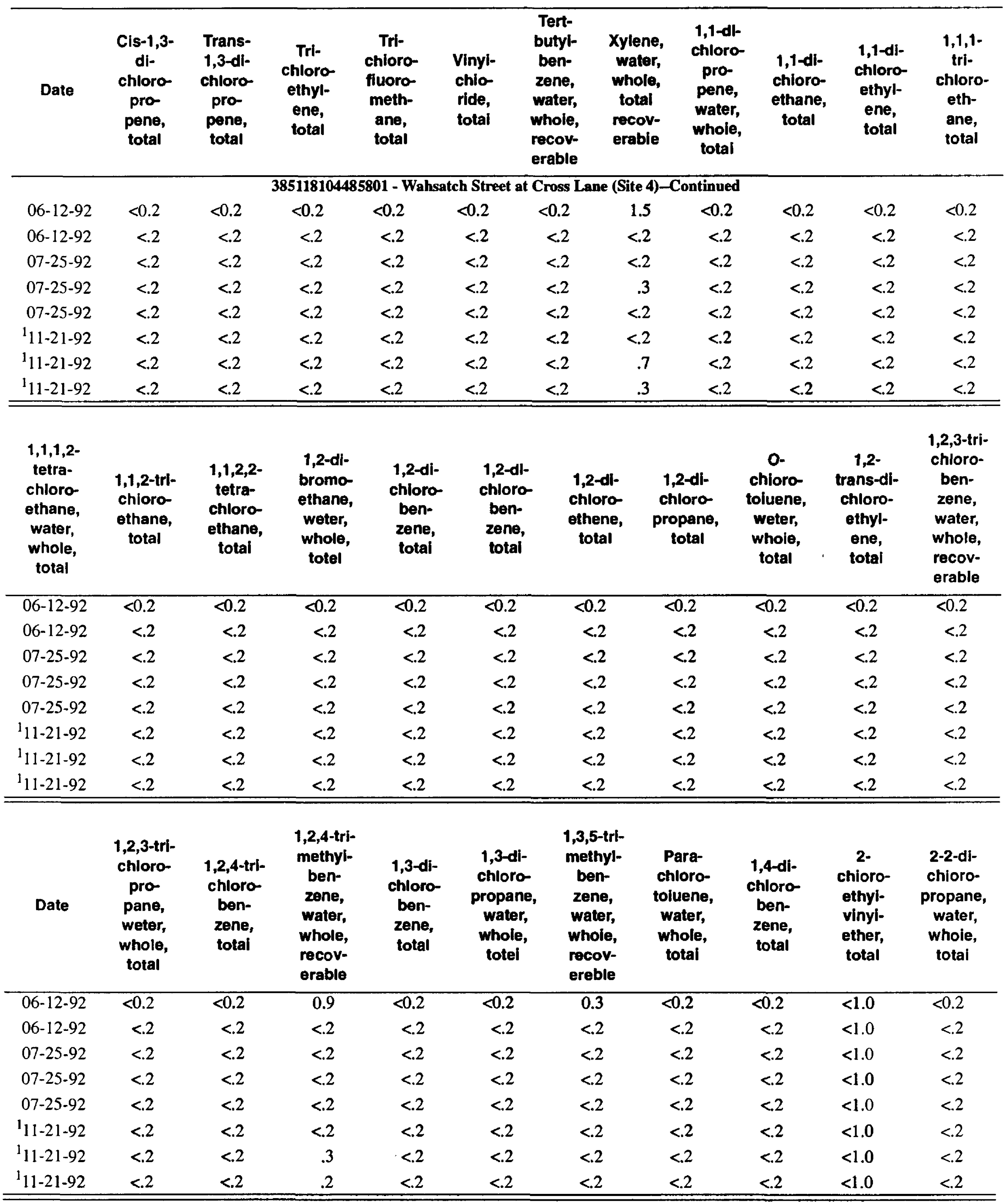


Table 18. Selected volatile organic compounds for storm-runoff sites in Colorado Springs--Continued

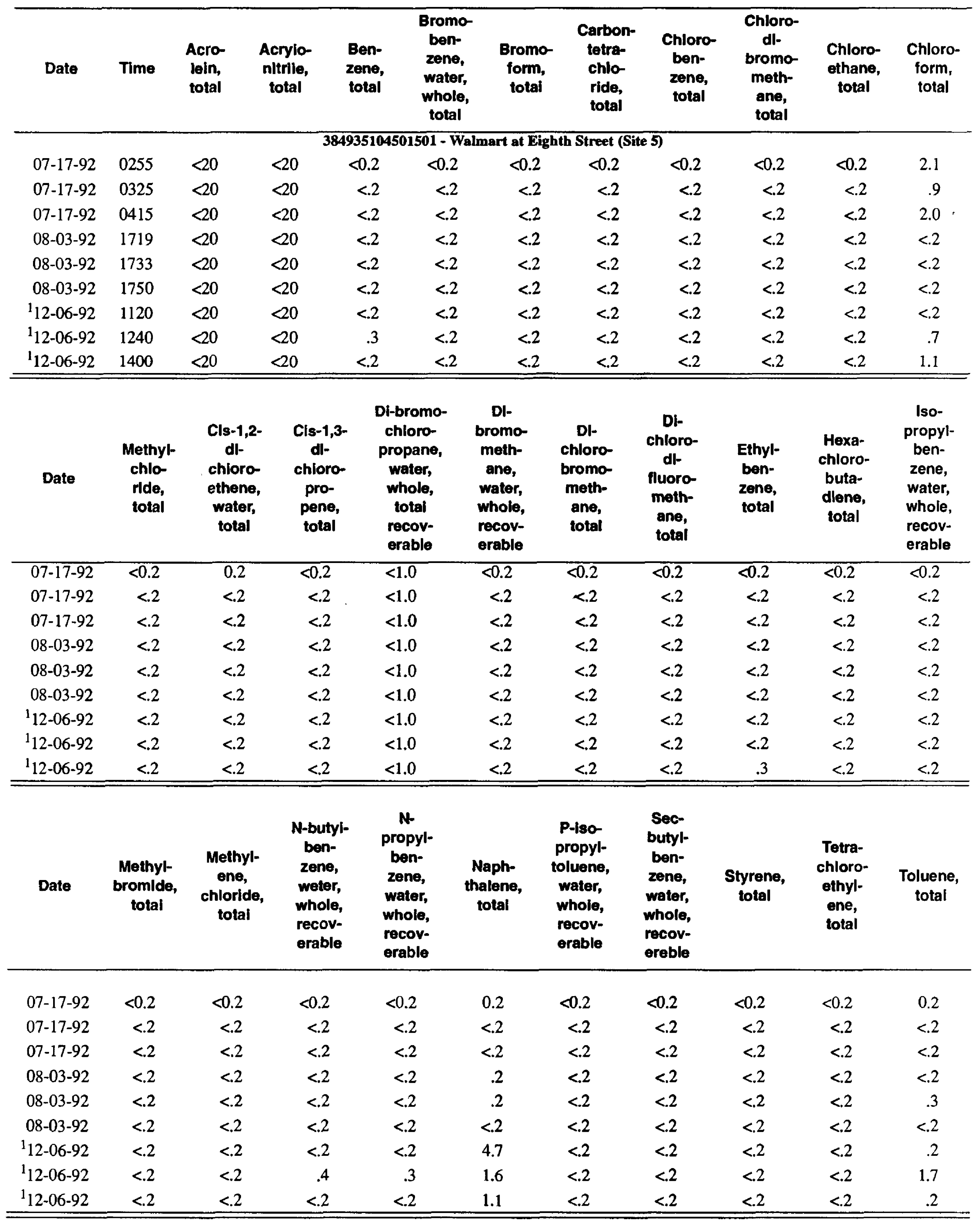

50 Water Quality of Storm Runoff and Comparison of Procedures for Estimating Storm-Runoff Loads, Volume, EventMean Concentrations, and the Mean Load for a Storm for Selected Propertles and Constltuents for Coiorado Springs, 
Table 18. Selected volatile organic compounds for storm-runoff sites in Colorado Springs--Continued

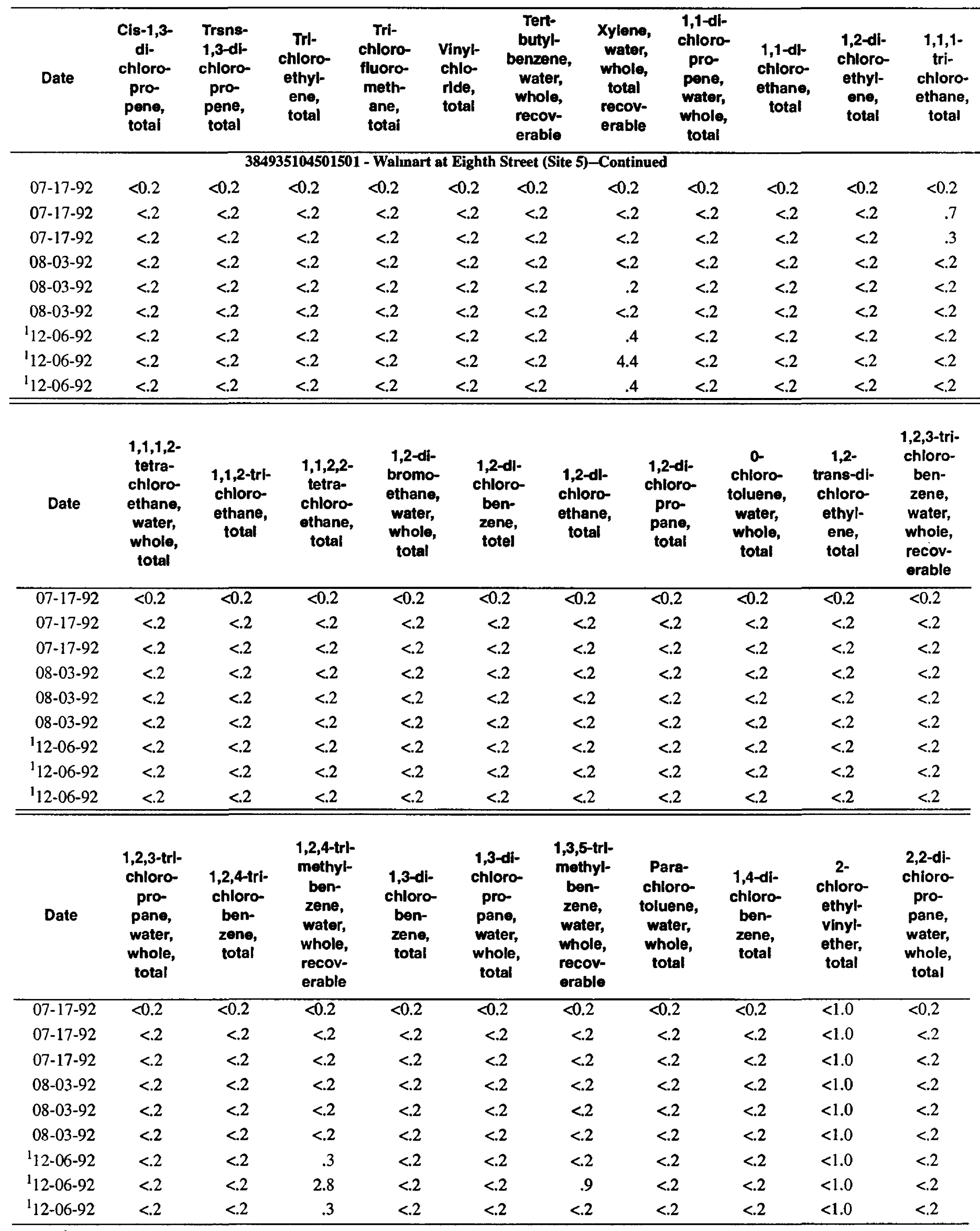

${ }^{1}$ Snowmelt-runnoff sample. 
Table 19. Chemical oxygen demand, 5-day biochemical oxygen demand, specific conductance, alkalinity, dissolved solids, suspended solids, major ions, nutrients, and total-recoverable metals for storm-runoff sites in Colorado Springs

[mg/L, milligrams per liter; $\mu \mathrm{S} / \mathrm{cm}$, microsiemens per centimeter at 25 degrees Celsius; $\mu \mathrm{g} / \mathrm{L}$, micrograms per liter; lab, laboratory; dashes indicate no data; $<$, less than]

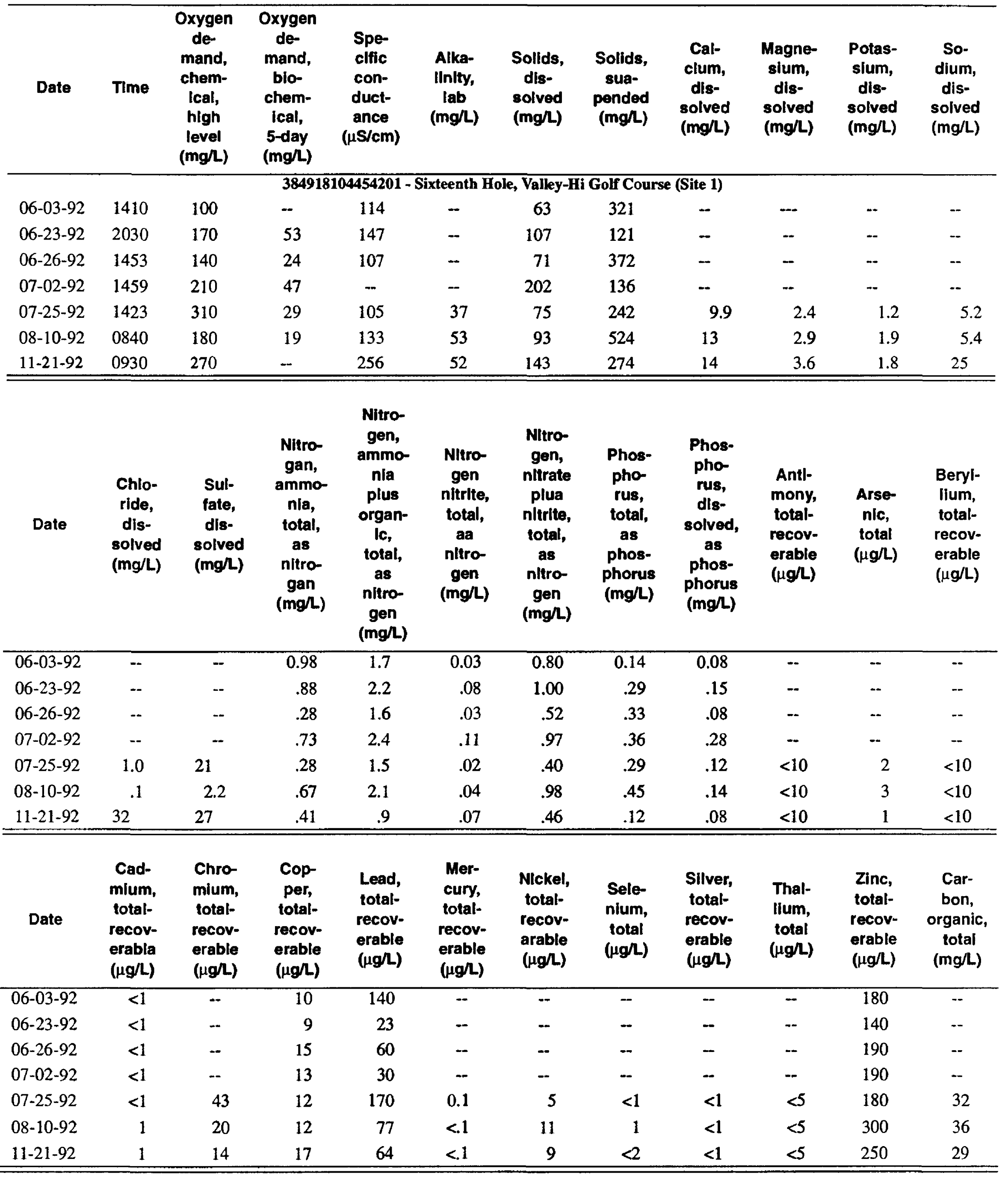

52 Water Quality of Storm Runoff and Comparison of Procedures for Estimating Storm-Runoff Loads, Volume, EventMean Concentratlons, and the Mean Load for a Storm for Selected Propertles and Constltuents for Colorado Springs, 
Table 19. Chemical oxygen demand, 5-day biochemical oxygen demand, specific conductance, alkalinity, dissolved solids, suspended solids, major ions, nutrients, and total-recoverable metals for storm-runoff sites in Colorado Springs--Continued

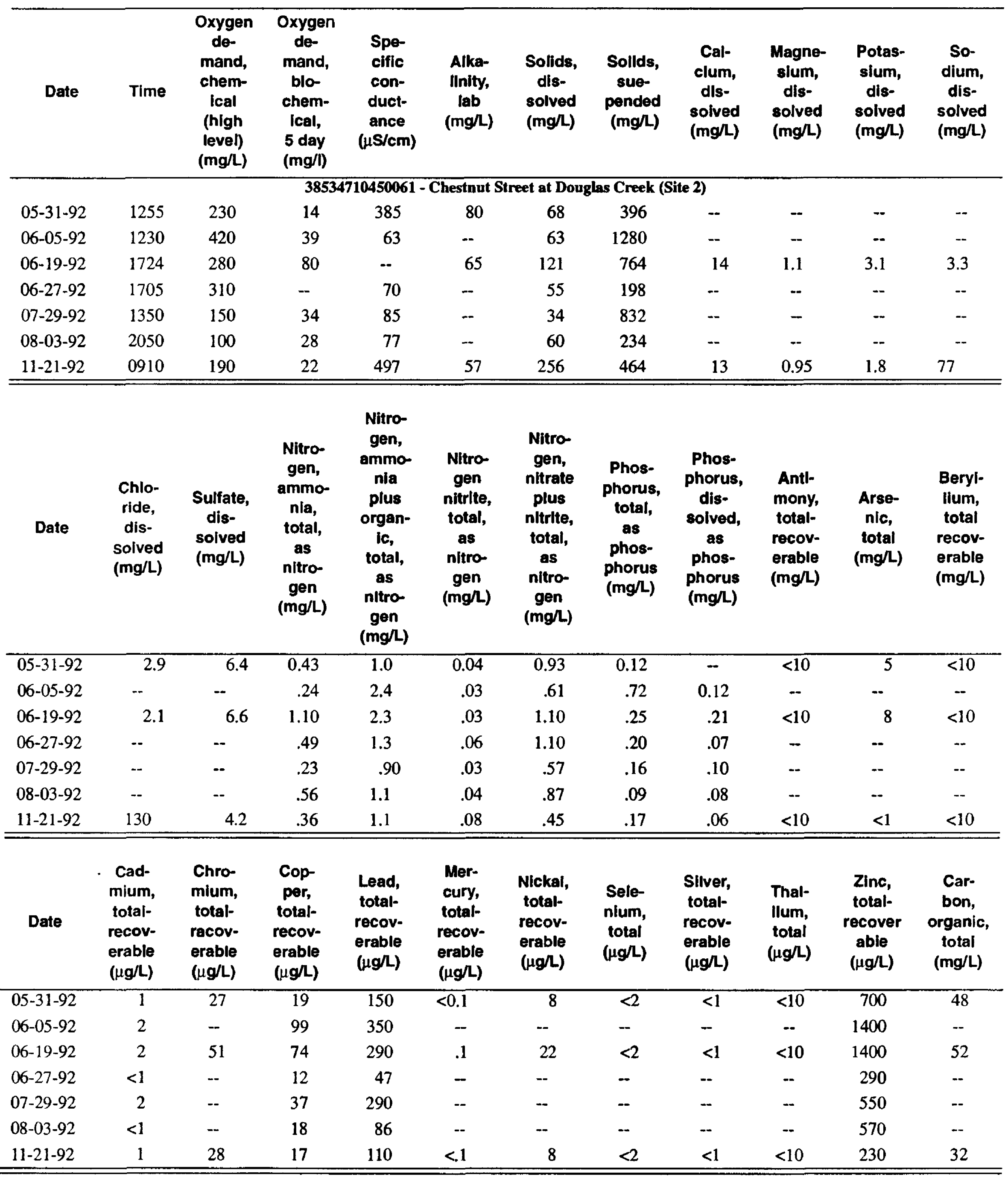


Table 19. Chemical oxygen demand, 5-day biochemical oxygen demand, specific conductance, alkalinity, dissolved solids, suspended solids, major ions, nutrients, and total-recoverable metals for storm-runoff sites in Colorado Springs--Continued

\begin{tabular}{|c|c|c|c|c|c|c|c|c|c|c|c|}
\hline Date & Time & $\begin{array}{l}\text { Oxygen } \\
\text { de- } \\
\text { mand, } \\
\text { chem- } \\
\text { Ical } \\
\text { (high } \\
\text { level) } \\
\text { (mgll) }\end{array}$ & $\begin{array}{l}\text { Oxygen } \\
\text { de- } \\
\text { mand, } \\
\text { bio- } \\
\text { chem- } \\
\text { ical, } \\
5 \text { day } \\
\text { (mg/l) }\end{array}$ & $\begin{array}{l}\text { Spe- } \\
\text { clfic } \\
\text { con- } \\
\text { duct- } \\
\text { ance } \\
(\mu S / c m)\end{array}$ & $\begin{array}{c}\text { Alka- } \\
\text { linity, } \\
\text { lab } \\
\text { (mg/L) }\end{array}$ & $\begin{array}{l}\text { Sollds, } \\
\text { dls- } \\
\text { solved } \\
\text { (mg/l) }\end{array}$ & $\begin{array}{c}\text { Solids, } \\
\text { aus- } \\
\text { panded } \\
\text { (mg/l) }\end{array}$ & $\begin{array}{l}\text { Cal- } \\
\text { clum, } \\
\text { dls- } \\
\text { solved } \\
\text { (mg/L) }\end{array}$ & $\begin{array}{l}\text { Magne- } \\
\text { slum, } \\
\text { dls- } \\
\text { solved } \\
\text { (mg/h) }\end{array}$ & $\begin{array}{l}\text { Potas- } \\
\text { sium, } \\
\text { dis- } \\
\text { solved } \\
\text { (mg/l) }\end{array}$ & $\begin{array}{l}\text { So- } \\
\text { dium, } \\
\text { dis- } \\
\text { solved } \\
\text { (mg/L) }\end{array}$ \\
\hline \multicolumn{12}{|c|}{ 385240104493601 - Beacon Street at Bnchanan Street (Site 3) } \\
\hline $06-05-92$ & 1240 & 170 & 33 & 92 & 40 & 74 & 330 & 13 & 0.86 & 2.2 & 2.9 \\
\hline $06-19-92$ & 1735 & 300 & 66 & 101 & 44 & 103 & 340 & 13 & .91 & 3.1 & 2.9 \\
\hline $06-23-92$ & 2044 & 200 & 42 & 110 & -- & 87 & 101 & - & -- & -- & -- \\
\hline $06-27-92$ & 1712 & 160 & 51 & 99 & -- & 77 & 162 & - & - & -- & -- \\
\hline $08-02-92$ & 1845 & 270 & 74 & 133 & -- & 168 & 220 & - & -- & -- & -- \\
\hline $08-03-92$ & 2055 & 120 & 26 & 59 & -- & 54 & 272 & - & - & -- & -- \\
\hline $11-11-92$ & 0759 & 260 & 62 & 238 & 41 & 137 & 116 & 13 & 1.0 & 2.6 & 25 \\
\hline Date & $\begin{array}{l}\text { Chio- } \\
\text { ride, } \\
\text { dis- } \\
\text { soived } \\
\text { (mgll) }\end{array}$ & $\begin{array}{l}\text { Sulfate, } \\
\text { dis- } \\
\text { solved } \\
\text { (mg/l) }\end{array}$ & $\begin{array}{l}\text { Nitro- } \\
\text { gen, } \\
\text { ammo- } \\
\text { nla, } \\
\text { total, } \\
\text { as } \\
\text { nitro- } \\
\text { gen } \\
\text { (mg/L) }\end{array}$ & $\begin{array}{c}\text { Nitro- } \\
\text { gen, } \\
\text { ammo- } \\
\text { nia } \\
\text { plus } \\
\text { organ- } \\
\text { ic, } \\
\text { total, } \\
\text { as } \\
\text { nitro- } \\
\text { gen } \\
\text { (mg/) }\end{array}$ & $\begin{array}{l}\text { Nitro- } \\
\text { gen } \\
\text { nitrite, } \\
\text { totai, } \\
\text { as } \\
\text { nitro- } \\
\text { gen } \\
\text { (mg/l) }\end{array}$ & $\begin{array}{c}\text { Nitro- } \\
\text { gen, } \\
\text { nitrate } \\
\text { plus } \\
\text { nitrite, } \\
\text { total, } \\
\text { as } \\
\text { nitro- } \\
\text { gen } \\
\text { (mg/l) }\end{array}$ & $\begin{array}{c}\text { Phos- } \\
\text { phorus, } \\
\text { total, } \\
\text { as } \\
\text { phoa- } \\
\text { phorus } \\
\text { (mg/l) }\end{array}$ & $\begin{array}{c}\text { Phos- } \\
\text { phorua, } \\
\text { dis- } \\
\text { solved, } \\
\text { as } \\
\text { phos- } \\
\text { phorus } \\
\text { (mgll) }\end{array}$ & $\begin{array}{l}\text { Antl- } \\
\text { mony, } \\
\text { total- } \\
\text { recov- } \\
\text { erable } \\
\text { (mgll) }\end{array}$ & $\begin{array}{l}\text { Arse- } \\
\text { nic, } \\
\text { totai } \\
(\mathrm{mg} / \mathrm{L})\end{array}$ & $\begin{array}{l}\text { Beryl- } \\
\text { llum, } \\
\text { total } \\
\text { recov- } \\
\text { erable } \\
\text { (mg/L) }\end{array}$ \\
\hline $06-05-92$ & 3.4 & 8.5 & 0.76 & 2.9 & .04 & 0.84 & 0.30 & 0.13 & $<20$ & 1 & $<10$ \\
\hline $06-19-92$ & 2.9 & 6.4 & 1.30 & 3.5 & .04 & 1.00 & .58 & .51 & $<10$ & $<1$ & $<10$ \\
\hline $06-23-92$ & -- & -- & .99 & 2.7 & .07 & 1.10 & .27 & .17 & - & -- & -- \\
\hline $06-27-92$ & -- & - & 1.50 & 3.7 & .06 & 1.00 & .46 & .20 & - & -- & - \\
\hline $08-02-92$ & - & - & 1.50 & 4.0 & .04 & 1.40 & .44 & .30 & -- & -- & -- \\
\hline $08-03-92$ & - & -- & .48 & 1.6 & .03 & .66 & .16 & .10 & -- & -- & - \\
\hline $11-11-92$ & 42 & 5.3 & .57 & 1.8 & .07 & .68 & .33 & .18 & $<10$ & 1 & $<10$ \\
\hline Date & $\begin{array}{l}\text { Cad- } \\
\text { mium, } \\
\text { total- } \\
\text { recov- } \\
\text { erable } \\
(\mu g / L)\end{array}$ & $\begin{array}{l}\text { Chro- } \\
\text { mium, } \\
\text { total- } \\
\text { recov- } \\
\text { erable } \\
(\mu g / L)\end{array}$ & $\begin{array}{l}\text { Cop- } \\
\text { per, } \\
\text { total- } \\
\text { recov- } \\
\text { erable } \\
(\mu g / L)\end{array}$ & $\begin{array}{l}\text { Lead, } \\
\text { total- } \\
\text { recov- } \\
\text { erable } \\
\text { ( } \mu g / \text { ) }\end{array}$ & $\begin{array}{l}\text { Mer- } \\
\text { cury, } \\
\text { total- } \\
\text { recov- } \\
\text { erable } \\
(\mu g / L)\end{array}$ & $\begin{array}{c}\text { Nickel, } \\
\text { total- } \\
\text { recov- } \\
\text { erable } \\
(\mu g / L)\end{array}$ & $\begin{array}{l}\text { Sele- } \\
\text { nium, } \\
\text { lotal } \\
(\mu g / L)\end{array}$ & $\begin{array}{l}\text { Silver, } \\
\text { total- } \\
\text { recov- } \\
\text { erable } \\
(\mu g /))\end{array}$ & $\begin{array}{l}\text { Thal- } \\
\text { lium, } \\
\text { total } \\
(\mu g / L)\end{array}$ & $\begin{array}{l}\text { ZInc, } \\
\text { total- } \\
\text { recov- } \\
\text { erable } \\
(\mu g / L)\end{array}$ & $\begin{array}{c}\text { Car- } \\
\text { bon, } \\
\text { organic, } \\
\text { total } \\
\text { (mg/L) }\end{array}$ \\
\hline $06-05-92$ & 2 & 18 & 17 & 85 & $<0.1$ & 12 & $<2$ & $<1$ & $<5$ & 280 & 68 \\
\hline $06-19-92$ & 2 & 27 & 24 & 83 & $<.1$ & 17 & $<2$ & 1 & $<10$ & 350 & 83 \\
\hline $06-23-92$ & $<1$ & -- & 13 & 23 & - & -- & - & - & -- & 160 & -- \\
\hline $06-27-92$ & $<1$ & -- & 13 & 42 & -- & -- & -- & - & -- & 150 & - \\
\hline $08-02-92$ & 2 & - & 22 & 53 & -- & - & -- & - & - & 400 & -- \\
\hline 08-03-92 & 2 & -- & 12 & 97 & - & - & -- & -. & -- & 340 & - \\
\hline $11-11-92$ & 1 & 8 & 14 & 55 & $<.1$ & 6 & $<2$ & $<1$ & $<10$ & 200 & 52 \\
\hline
\end{tabular}

54 Water Quality of Storm Runoff and Comparison of Procedures for Estimating Storm-Runoff Loads, Volume, EventMean Concentrations, and the Mean Load for a Storm for Selected Properties and Constituents for Colorado Springs, 
Table 19. Chemical oxygen demand, 5-day biochemical oxygen demand, specific conductance, alkalinity, dissolved solids, suspended solids, major ions, nutrients, and total-recoverable metals for storm-runoff sites in Colorado Springs--Continued

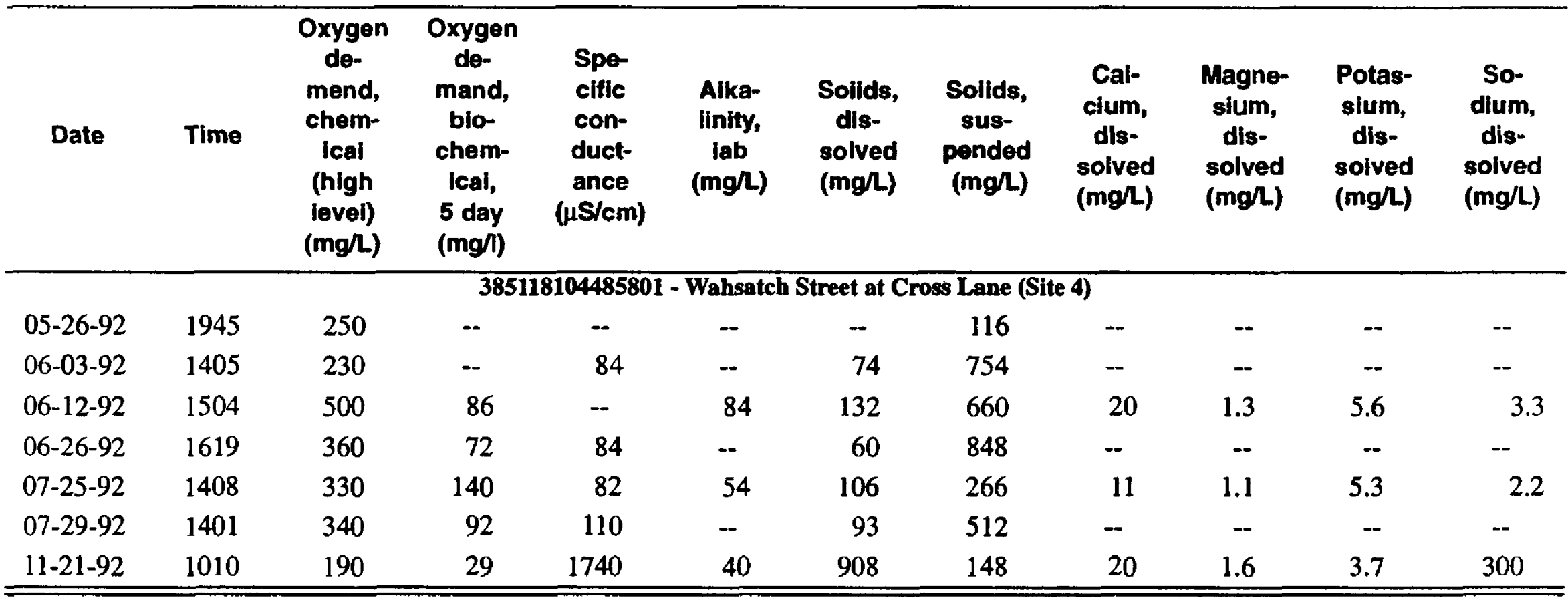

\begin{tabular}{|c|c|c|c|c|c|c|c|c|c|c|c|}
\hline Date & $\begin{array}{l}\text { Chlo- } \\
\text { ride, } \\
\text { dis- } \\
\text { solved } \\
\text { (mg/L) }\end{array}$ & $\begin{array}{c}\text { Sulfete, } \\
\text { dis- } \\
\text { solved } \\
\text { (mg/) }\end{array}$ & $\begin{array}{c}\text { Nitro- } \\
\text { gen, } \\
\text { ammo- } \\
\text { nia, } \\
\text { totai, } \\
\text { as } \\
\text { nitro- } \\
\text { gen } \\
\text { (mg/L) }\end{array}$ & $\begin{array}{c}\text { Nitro- } \\
\text { gen, } \\
\text { ammo- } \\
\text { nia } \\
\text { plus } \\
\text { organ- } \\
\text { ic, } \\
\text { total, } \\
\text { as } \\
\text { nitro- } \\
\text { gen } \\
\text { (mgl) }\end{array}$ & $\begin{array}{c}\text { Nitro- } \\
\text { gen } \\
\text { nitrite, } \\
\text { totai, } \\
\text { as } \\
\text { nitro- } \\
\text { gen } \\
\text { (mg/L) }\end{array}$ & $\begin{array}{c}\text { Nitro- } \\
\text { gen, } \\
\text { nitrate } \\
\text { plus } \\
\text { nitrite, } \\
\text { total, } \\
\text { as } \\
\text { nitro- } \\
\text { gen } \\
\text { (mgl) }\end{array}$ & $\begin{array}{l}\text { Phos- } \\
\text { phorus, } \\
\text { total, } \\
\text { as } \\
\text { phos- } \\
\text { phorus } \\
\text { (mg/L) }\end{array}$ & $\begin{array}{l}\text { Phos- } \\
\text { phorus, } \\
\text { dis- } \\
\text { solved, } \\
\text { as } \\
\text { phos- } \\
\text { phorus } \\
\text { (mg/L) }\end{array}$ & $\begin{array}{l}\text { Anti- } \\
\text { mony, } \\
\text { totai- } \\
\text { recov- } \\
\text { erabie } \\
\text { (mg/l) }\end{array}$ & $\begin{array}{c}\text { Arse- } \\
\text { nic, } \\
\text { total } \\
\text { (mgh) }\end{array}$ & $\begin{array}{l}\text { Beryl- } \\
\text { lium, } \\
\text { totsl } \\
\text { recov- } \\
\text { ereble } \\
\text { (mg/L) }\end{array}$ \\
\hline $05-26-92$ & -- & - & 1.00 & 5.0 & 0.05 & 0.38 & 1.20 & - & -- & - & -- \\
\hline 06-03-92 & -- & -- & .53 & 4.9 & .06 & .88 & .47 & 0.26 & -- & -- & -. \\
\hline $06-12-92$ & 3.0 & 6.5 & .72 & 5.3 & .07 & .83 & 1.10 & .38 & $<10$ & 5 & $<10$ \\
\hline $06-26-92$ & -- & -- & .27 & 3.8 & .04 & .47 & .95 & .28 & -- & -- & -- \\
\hline $07-25-92$ & 2.1 & 5.6 & .16 & 3.1 & .03 & .37 & .72 & .27 & $<10$ & 3 & $<10$ \\
\hline $07-29-92$ & -- & -- & .35 & 2.8 & .04 & .83 & .60 & -- & -- & -- & -- \\
\hline $11-21-92$ & 470 & 4.5 & .39 & 1.6 & .08 & .36 & .22 & .11 & $<10$ & $<1$ & $<10$ \\
\hline Date & $\begin{array}{c}\text { Cad- } \\
\text { mium, } \\
\text { total- } \\
\text { recov- } \\
\text { ersble } \\
(\mu g / L)\end{array}$ & $\begin{array}{l}\text { Chro- } \\
\text { mium, } \\
\text { total- } \\
\text { recov- } \\
\text { erable } \\
(\mu g / L)\end{array}$ & $\begin{array}{l}\text { Cop- } \\
\text { per, } \\
\text { total- } \\
\text { recov- } \\
\text { ersbie } \\
(\mu g / L)\end{array}$ & $\begin{array}{l}\text { Lead, } \\
\text { total- } \\
\text { recov- } \\
\text { ereble } \\
(\mu g / L)\end{array}$ & $\begin{array}{l}\text { Mer- } \\
\text { cury, } \\
\text { totsi- } \\
\text { recov- } \\
\text { ersble } \\
(\mu g /))\end{array}$ & $\begin{array}{l}\text { Nickel, } \\
\text { total- } \\
\text { recov- } \\
\text { erabie } \\
(\mu g / L)\end{array}$ & $\begin{array}{l}\text { Sele- } \\
\text { nlum, } \\
\text { total } \\
(\mu g h)\end{array}$ & $\begin{array}{l}\text { Sllver, } \\
\text { total- } \\
\text { recov- } \\
\text { ereble } \\
(\mu g / L)\end{array}$ & $\begin{array}{l}\text { Thsi- } \\
\text { lium, } \\
\text { total } \\
\text { ( } \mu g /) \text { ) }\end{array}$ & $\begin{array}{l}\text { Zinc, } \\
\text { total- } \\
\text { recov- } \\
\text { ereble } \\
(\mu g / L)\end{array}$ & $\begin{array}{c}\text { Car- } \\
\text { bon, } \\
\text { organic, } \\
\text { total } \\
\text { (mg/L) }\end{array}$ \\
\hline $05-26-92$ & $<1$ & -- & 9 & 41 & -- & - & -- & -- & $\overline{--}$ & 110 & -- \\
\hline $06-03-92$ & 1 & -- & 12 & 120 & -- & -- & -. & - & -- & 220 & -- \\
\hline $06-12-92$ & 2 & 18 & 22 & 130 & $<0.1$ & 11 & $<2$ & $<1$ & $<10$ & 300 & 100 \\
\hline $06-26-92$ & 1 & -- & 15 & 130 & -- & - & -- &.- & -- & 310 & -- \\
\hline $07-25-92$ & $<1$ & 8 & 11 & 57 & $<.1$ & 4 & $<1$ & $<1$ & $<5$ & 140 & 100 \\
\hline $07-29-92$ & 1 & - & 17 & 110 & - & - & -- & - & -- & 240 & -- \\
\hline $11-21-92$ & $<1$ & 7 & 8 & 32 & $<.1$ & 4 & $<2$ & $<1$ & $<10$ & 110 & 18 \\
\hline
\end{tabular}


Table 19. Chemical oxygen demand, 5-day biochemical oxygen demand, specific conductance, alkalinity, dissolved solids, suspended solids, major ions, nutrients, and total-recoverable metals for storm-runoff sites in Colorado Springs--Continued

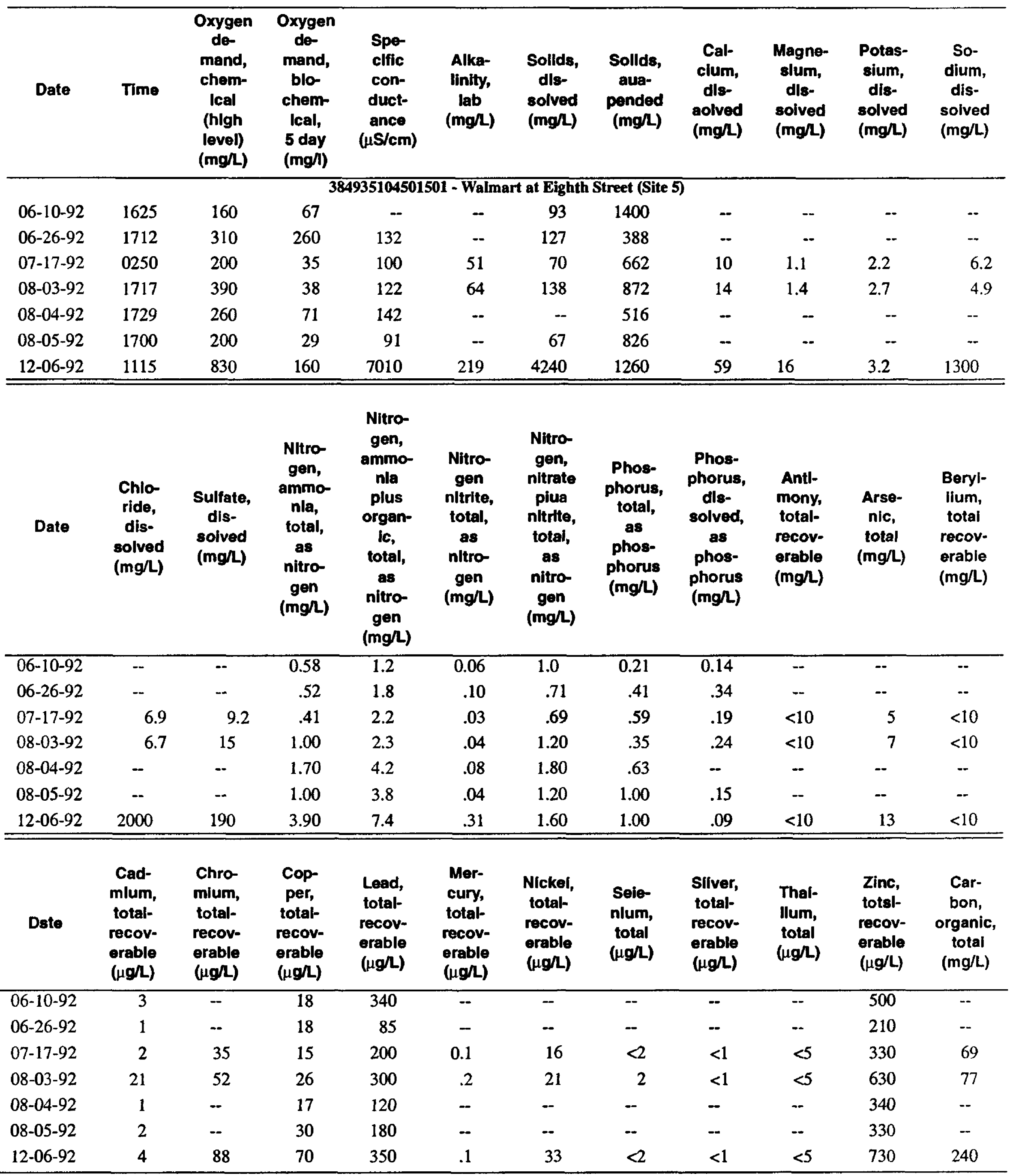

56 Water Quality of Storm Runoff and Comparison of Procedures for Estimating Storm-Runoff Loads, Volume, EventMean Concentrations, and the Mean Load for a Storm for Seiected Properties and Constltuents for Colorado Springs, Southeastern Colorado, 1992 


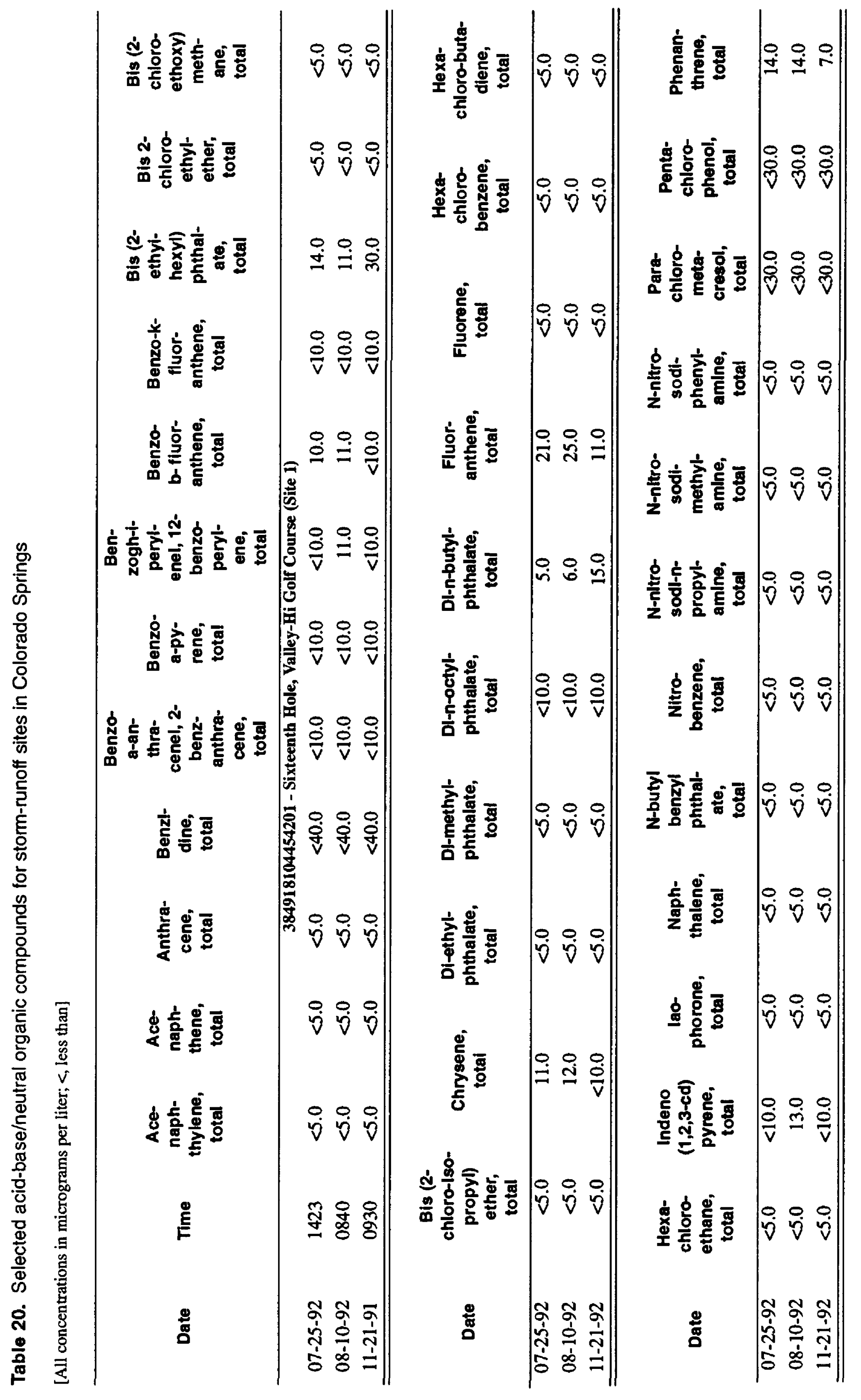




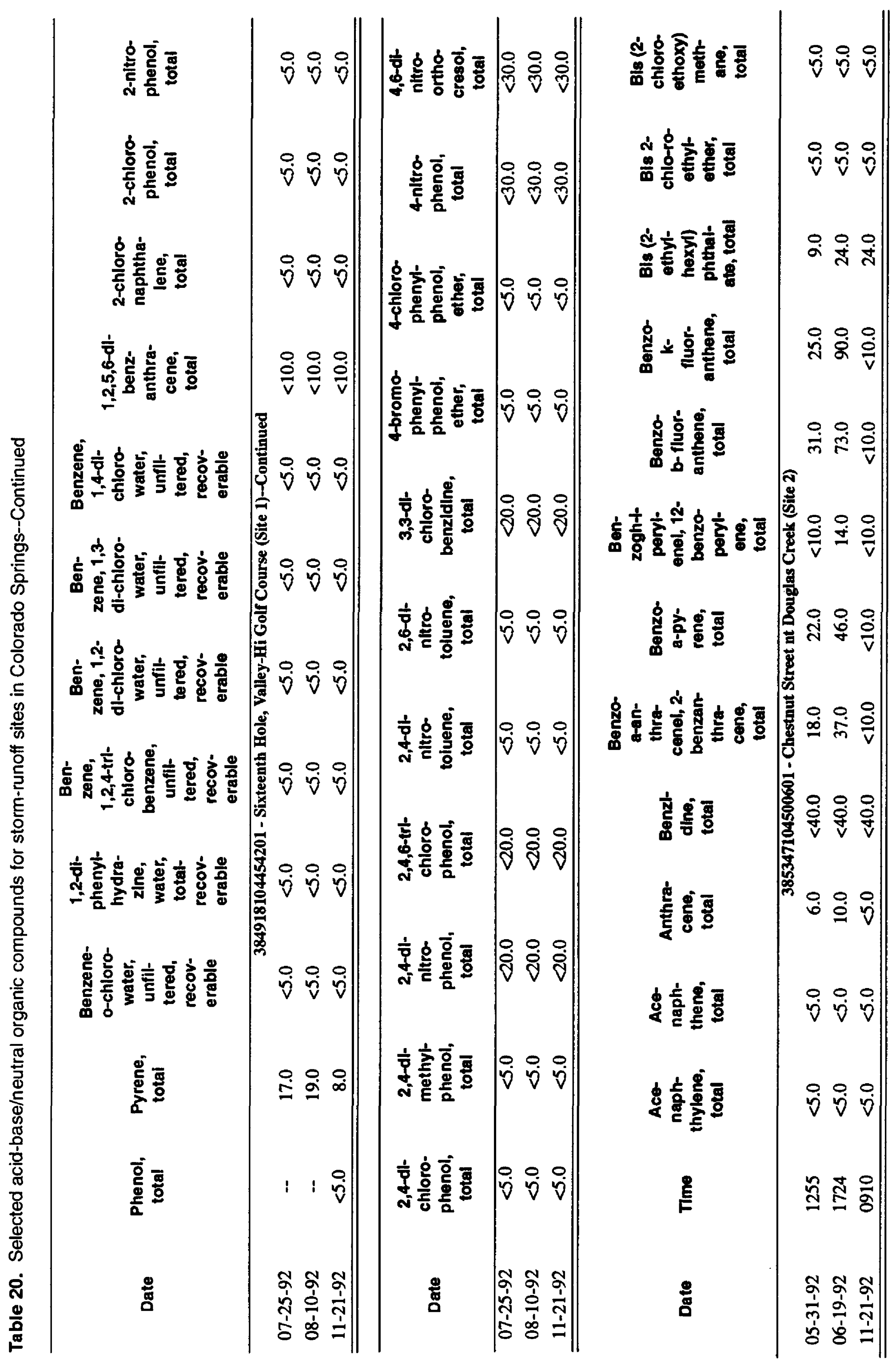




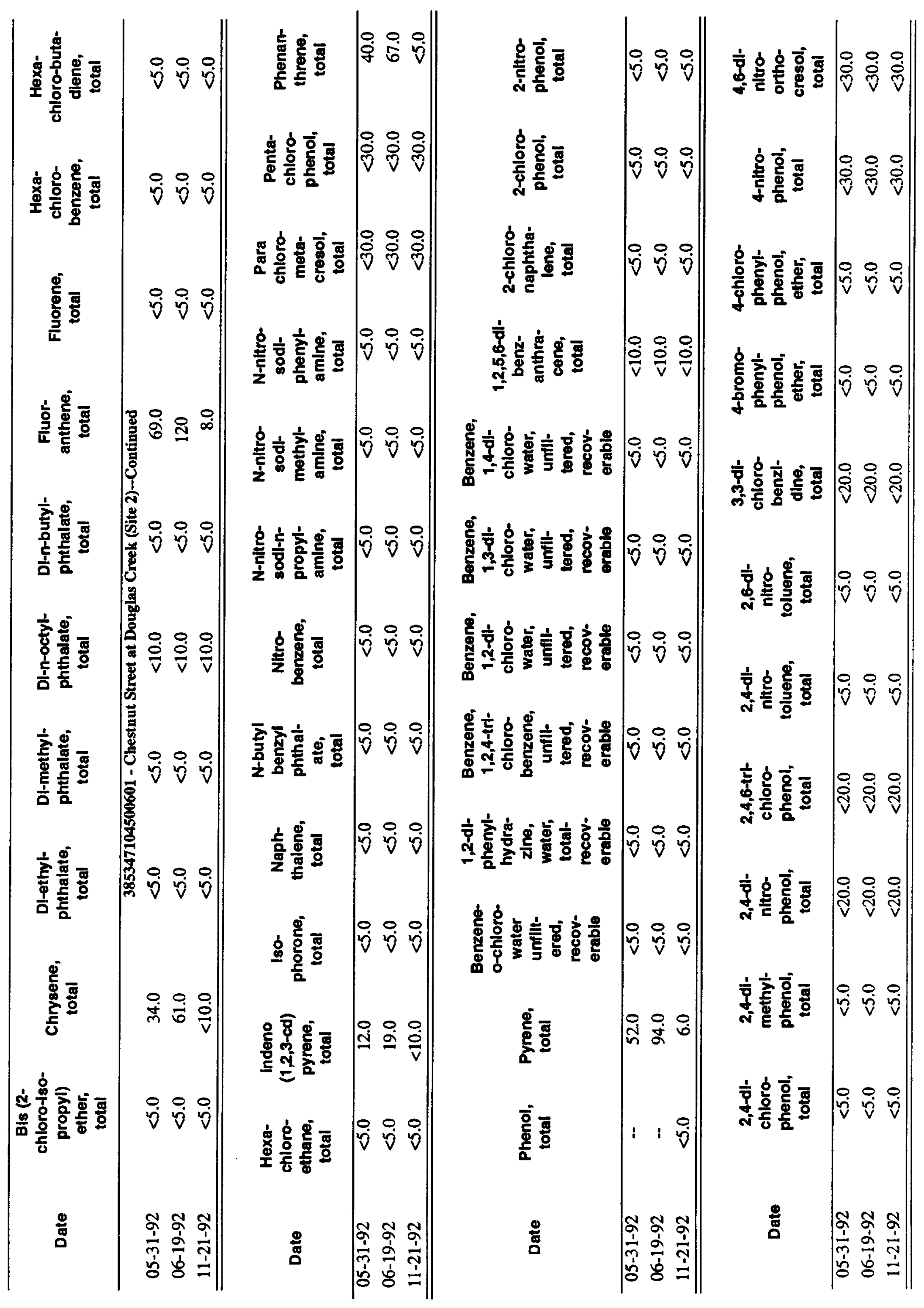




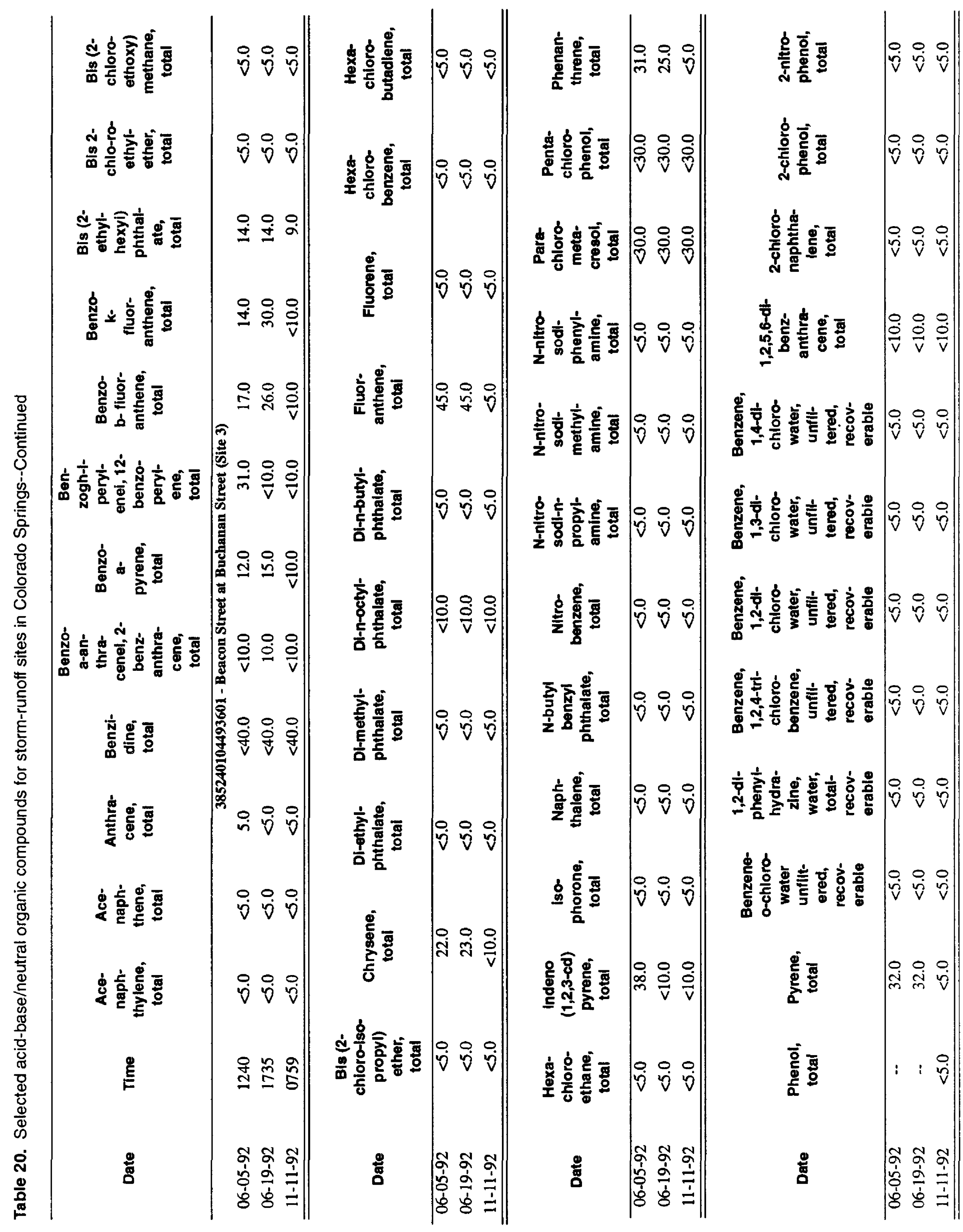

60 Water Quallty of Storm Runoff and Comparison of Procedures for Estimating Storm-Runoff Loads, Volume, Event-Mean Concentrations, and the Mean Load for a Storm for Selected Propertles and Constituents for Colorado Springs, Southeastern Colorado, 1992 


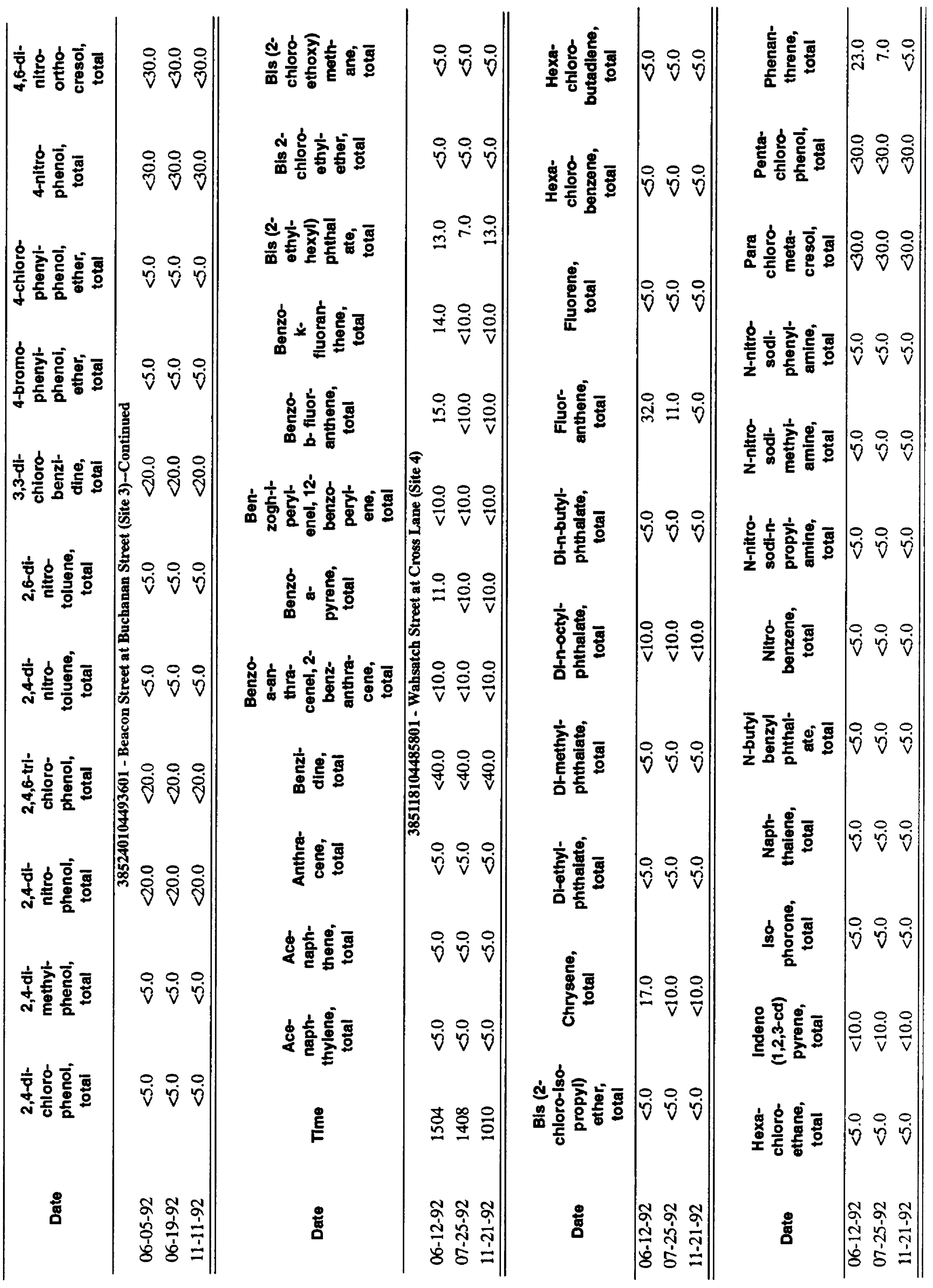




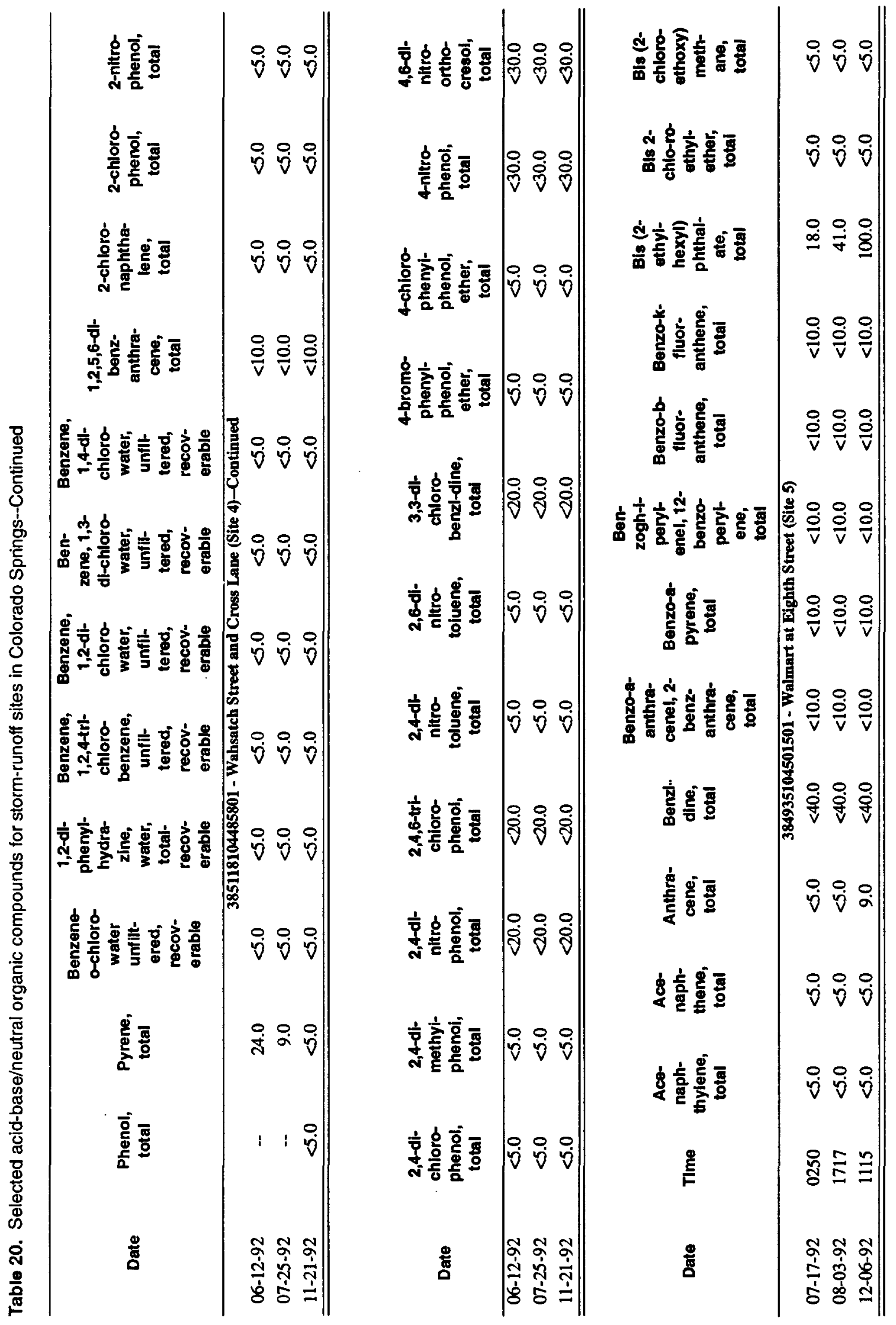

62 Water Quality of Storm Runoff and Comparison of Procedures for Estimating Storm-Runoff Loads, Volume, Event-Mean Concentrations, and the Mean Load for a Storm for Selected Properties and Constltuents for Colorado Springs, Southeastern Coiorado, 1992 


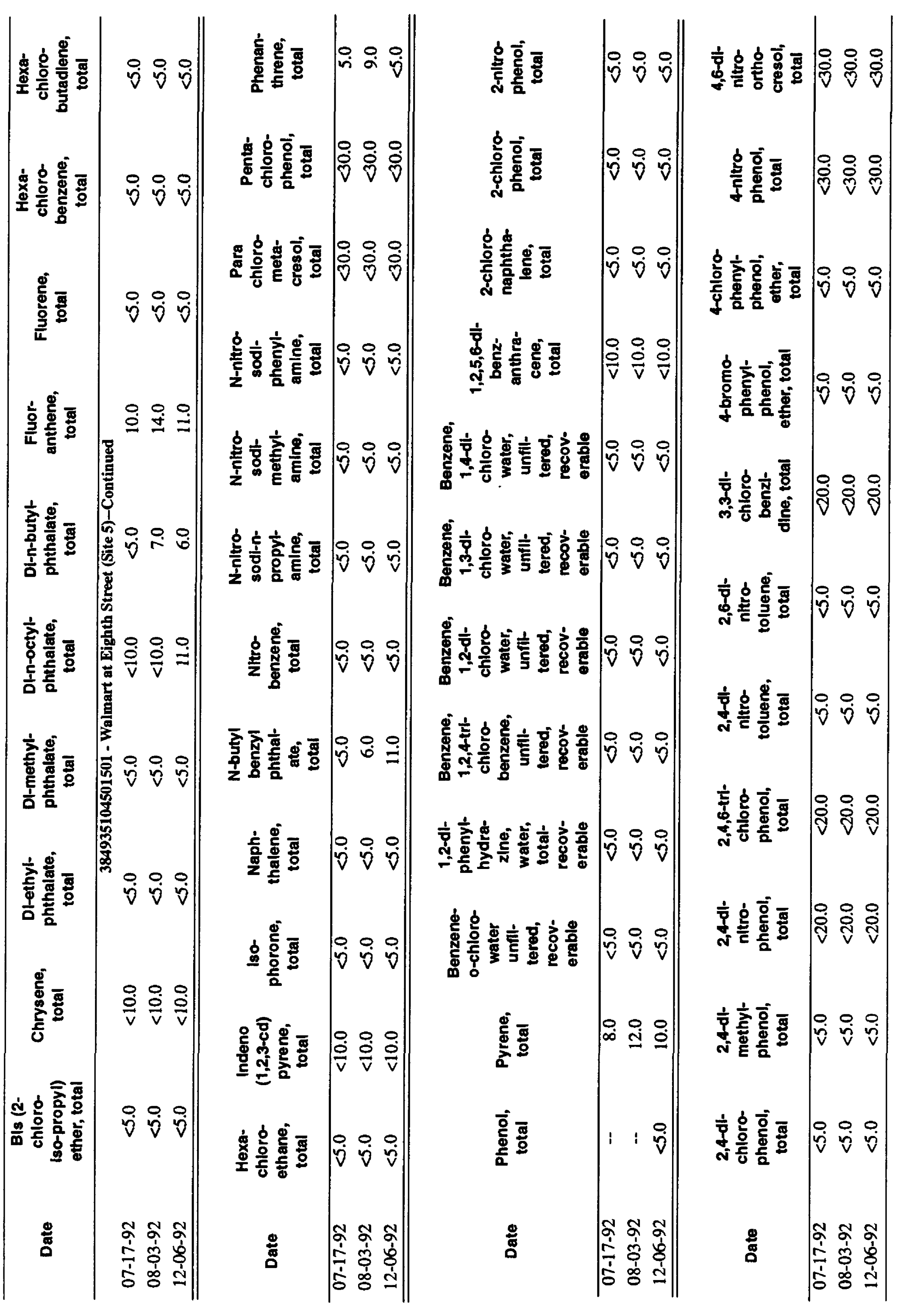


Table 21. Selected pesticide compounds for storm-runoff sites in Colorado Springs

[All concentrations in micrograms per liter; $<$, less than]

\begin{tabular}{|c|c|c|c|c|c|c|c|c|c|c|}
\hline Date & Tlme & $\begin{array}{c}\text { Aldrln, } \\
\text { total }\end{array}$ & $\begin{array}{l}\text { BHC } \\
\text { Alpha, } \\
\text { total }\end{array}$ & \multicolumn{7}{|c|}{ Aroclor, PCB, total } \\
\hline \multicolumn{11}{|c|}{38491810445201 - Sixteenth Hole, Valley-Hi Golf Course (Site 1) } \\
\hline $07-25-92$ & 1423 & $<0.04$ & $<0.03$ & $<0.1$ & $<1.0$ & $<0.1$ & $<0.1$ & $<0.1$ & $<0.1$ & $<0.1$ \\
\hline $08-10-92$ & 0840 & $<.04$ & $<.03$ & $<.1$ & $<1.0$ & $<.1$ & $<.1$ & $<.1$ & $<.1$ & $<.1$ \\
\hline $11-21-92$ & 0930 & $<.04$ & $<.03$ & $<.1$ & $<1.0$ & $<.1$ & $<.1$ & $<1$ & $<.1$ & $<.1$ \\
\hline
\end{tabular}

\begin{tabular}{|c|c|c|c|c|c|c|c|c|c|}
\hline Date & $\begin{array}{c}\text { Beta- } \\
\text { benzene, } \\
\text { hexa- } \\
\text { chloride, } \\
\text { total }\end{array}$ & $\begin{array}{c}\text { Chlor- } \\
\text { dane, } \\
\text { cls, } \\
\text { water, } \\
\text { whole, } \\
\text { total }\end{array}$ & $\begin{array}{l}\text { Chlor- } \\
\text { dane, } \\
\text { total }\end{array}$ & $\begin{array}{c}\text { Chlor- } \\
\text { dane, } \\
\text { trans, } \\
\text { water, } \\
\text { whole, } \\
\text { total }\end{array}$ & $\begin{array}{c}\text { Delta, } \\
\text { benzene, } \\
\text { hexa- } \\
\text { chloride, } \\
\text { tolal }\end{array}$ & $\begin{array}{l}\text { DI- } \\
\text { eldrin, } \\
\text { total }\end{array}$ & $\begin{array}{l}\text { Endo- } \\
\text { sulfan- } \\
\text { bota, } \\
\text { total }\end{array}$ & $\begin{array}{c}\text { Endo- } \\
\text { sulfan I, } \\
\text { Alpha, } \\
\text { water, } \\
\text { whole, } \\
\text { recov. } \\
\text { erable }\end{array}$ & $\begin{array}{l}\text { Endo- } \\
\text { sulfan, } \\
\text { suifate, } \\
\text { total }\end{array}$ \\
\hline $07-25-92$ & $<0.03$ & $<0.10$ & $<0.1$ & $<0.10$ & $<0.09$ & $<0.02$ & $<0.04$ & $<0.10$ & $<0.60$ \\
\hline $11-21-92$ & $<.03$ & $<.10$ & $<.1$ & $<.10$ & $<.09$ & $<.02$ & $<.04$ & $<.10$ & $<.60$ \\
\hline
\end{tabular}

\begin{tabular}{|c|c|c|c|c|c|c|c|c|c|}
\hline Date & $\begin{array}{c}\text { Endrin, } \\
\text { alde- } \\
\text { hyde, } \\
\text { total }\end{array}$ & $\begin{array}{l}\text { Endrin } \\
\text { water, } \\
\text { unfilt- } \\
\text { ered, } \\
\text { recov- } \\
\text { erable }\end{array}$ & $\begin{array}{c}\text { Gamma, } \\
\text { BHC, } \\
\text { LIndane, } \\
\text { total }\end{array}$ & $\begin{array}{l}\text { Hepta- } \\
\text { chlor, } \\
\text { total }\end{array}$ & $\begin{array}{l}\text { Hepla- } \\
\text { chlor- } \\
\text { epoxide, } \\
\text { total }\end{array}$ & $\begin{array}{c}\text { Tox- } \\
\text { aphene, } \\
\text { total }\end{array}$ & $\begin{array}{l}P, p^{\prime} \\
\text { DDD, } \\
\text { total }\end{array}$ & $\begin{array}{l}\text { p,p' } \\
\text { DDE, } \\
\text { totsi }\end{array}$ & $\begin{array}{l}\text { P,p' } \\
\text { DDT, } \\
\text { total }\end{array}$ \\
\hline $07-25-92$ & $<0.20$ & $<0.06$ & $<0.03$ & $<0.03$ & $<0.80$ & $<2$ & $<0.10$ & $<0.04$ & $<0.10$ \\
\hline $08-10-92$ & $<.20$ & $<.06$ & $<.03$ & $<.03$ & $<.80$ & $<2$ & $<.10$ & $<.04$ & $<.10$ \\
\hline
\end{tabular}

64 Water Quality of Storm Runoff and Comparlson of Procedures for Estimating Storm-Runoff Loads, Volume, EventMean Concentratlons, and the Mean Load for a Storm for Selected Properties and Constltuents for Colorado Springs, 
Tabie 21. Selected pesticide compounds for storm-runoff sites in Colorado Springs---Continued

\begin{tabular}{|c|c|c|c|c|c|c|c|c|c|c|}
\hline Date & Time & $\begin{array}{l}\text { Aldrin, } \\
\text { total }\end{array}$ & $\begin{array}{c}\text { BHC } \\
\text { Alpha, } \\
\text { total }\end{array}$ & \multicolumn{7}{|c|}{ Arocior, PCB, total } \\
\hline \multicolumn{11}{|c|}{ 385347104500601 - Chestnnt Street at Donglas Creek (Site 2) } \\
\hline $05-31-92$ & 1255 & $<0.04$ & $<0.03$ & $<0.1$ & $<1.0$ & $<0.1$ & $<0.1$ & $<0.1$ & $<0.1$ & $<0.1$ \\
\hline $06-19-92$ & 1728 & $<.04$ & $<.03$ & $<.1$ & $<1.0$ & $<.1$ & $<.1$ & $<.1$ & $<.1$ & $<.1$ \\
\hline $11-21-92$ & 0910 & $<.04$ & $<.03$ & $<.1$ & $<1.0$ & $<.1$ & $<.1$ & $<.1$ & $<.1$ & $<.1$ \\
\hline
\end{tabular}

\begin{tabular}{|c|c|c|c|c|c|c|c|c|c|}
\hline Date & $\begin{array}{c}\text { Beta- } \\
\text { benzene, } \\
\text { hexa- } \\
\text { chlorlde, } \\
\text { total }\end{array}$ & $\begin{array}{c}\text { Chlor- } \\
\text { dane, cls, } \\
\text { water, } \\
\text { whole, } \\
\text { total }\end{array}$ & $\begin{array}{l}\text { Chlor- } \\
\text { dane, } \\
\text { total }\end{array}$ & $\begin{array}{c}\text { Chlor- } \\
\text { dane, } \\
\text { trans, } \\
\text { water, } \\
\text { whole, } \\
\text { total }\end{array}$ & $\begin{array}{c}\text { Deita, } \\
\text { benzene, } \\
\text { hexa- } \\
\text { chioride, } \\
\text { total }\end{array}$ & $\begin{array}{l}\text { DI- } \\
\text { eldrin, } \\
\text { total }\end{array}$ & $\begin{array}{l}\text { Endo- } \\
\text { sulfan- } \\
\text { beta, } \\
\text { total }\end{array}$ & $\begin{array}{l}\text { Endo- } \\
\text { sulfan I, } \\
\text { Alpha, } \\
\text { water, } \\
\text { whole, } \\
\text { recov- } \\
\text { erable }\end{array}$ & $\begin{array}{l}\text { Endo- } \\
\text { sulfan, } \\
\text { sulfate, } \\
\text { fotal }\end{array}$ \\
\hline $05-31-92$ & $<0.03$ & $<0.10$ & $<0.1$ & $<0.10$ & $<0.09$ & $<0.02$ & $<0.06$ & $<0.10$ & $<0.60$ \\
\hline $11-21-92$ & $<.03$ & $<.10$ & $<.1$ & $<.10$ & $<.09$ & $<.02$ & $<.04$ & $<.10$ & $<.60$ \\
\hline Date & $\begin{array}{l}\text { Endrin, } \\
\text { alde- } \\
\text { hyde, } \\
\text { totel }\end{array}$ & $\begin{array}{l}\text { Endrin } \\
\text { water, } \\
\text { unfil- } \\
\text { tered, } \\
\text { recov- } \\
\text { erable }\end{array}$ & $\begin{array}{c}\text { Gamma, } \\
\text { BHC, } \\
\text { Lindane, } \\
\text { total }\end{array}$ & $\begin{array}{l}\text { Hepta- } \\
\text { chior, } \\
\text { total }\end{array}$ & $\begin{array}{l}\text { Hepta- } \\
\text { chlor- } \\
\text { epoxide, } \\
\text { total }\end{array}$ & $\begin{array}{c}\text { Tox- } \\
\text { aphene, } \\
\text { Iotal }\end{array}$ & $\begin{array}{c}\text { P,p' } \\
\text { DDD, } \\
\text { total }\end{array}$ & $\begin{array}{l}\text { P,p' } \\
\text { DDE, } \\
\text { total }\end{array}$ & $\begin{array}{l}\text { P,p' } \\
\text { DDT, } \\
\text { total }\end{array}$ \\
\hline $05-31-92$ & $<0.20$ & $<0.06$ & $<0.03$ & $<0.03$ & $<0.80$ & $<2$ & $<0.10$ & $<0.04$ & $<0.10$ \\
\hline $06-19-92$ & $<.20$ & $<.06$ & $<.03$ & $<.03$ & $<.80$ & $<2$ & $<.10$ & $<.04$ & $<.10$ \\
\hline $11-21-92$ & $<.20$ & $<.06$ & $<.03$ & $<.03$ & $<.80$ & $<2$ & $<.10$ & $<.04$ & $<.10$ \\
\hline
\end{tabular}


Table 21. Selected pesticide compounds for storm-runoff sites in Colorado Springs--Continued

\begin{tabular}{|c|c|c|c|c|c|c|c|c|c|c|}
\hline \multirow{2}{*}{ Date } & \multirow{2}{*}{ Time } & \multirow{2}{*}{$\begin{array}{l}\text { Aldrin, } \\
\text { total }\end{array}$} & \multirow{2}{*}{$\begin{array}{c}\text { BHC } \\
\text { Alpha, } \\
\text { total }\end{array}$} & \multicolumn{7}{|c|}{ Aroclor, PCB, total } \\
\hline & & & & 1016 & 1221 & 1232 & 1242 & 1248 & 1254 & 1260 \\
\hline \multicolumn{11}{|c|}{ 385240104493601 - Beacon Street at Buchanan Street (Site 3) } \\
\hline 06-05-92 & 1240 & $<0.04$ & $<0.03$ & $<0.1$ & $<1.0$ & $<0.1$ & $<0.1$ & $<0.1$ & $<0.1$ & $<0.1$ \\
\hline 06-19-92 & 1735 & $<.04$ & $<.03$ & $<1$ & $<1.0$ & $<1$ & $<.1$ & $<.1$ & $<.1$ & $<.1$ \\
\hline $11-11-92$ & 0759 & $<.04$ & $<.03$ & $<.1$ & $<1.0$ & $<.1$ & $<.1$ & $<1$ & $<.1$ & $<.1$ \\
\hline
\end{tabular}

\begin{tabular}{cccccccccc}
$\begin{array}{c}\text { Beta- } \\
\text { benzene, } \\
\text { hexa- } \\
\text { chlorlde, } \\
\text { total }\end{array}$ & $\begin{array}{c}\text { Chlor- } \\
\text { dane, cis, } \\
\text { water, } \\
\text { whole, } \\
\text { total }\end{array}$ & $\begin{array}{c}\text { Chior- } \\
\text { dane, } \\
\text { total }\end{array}$ & $\begin{array}{c}\text { Chlor- } \\
\text { dane, } \\
\text { trans, } \\
\text { water, } \\
\text { whole, } \\
\text { total }\end{array}$ & $\begin{array}{c}\text { Delta, } \\
\text { benzene, } \\
\text { hexa- } \\
\text { chiorlde, } \\
\text { total }\end{array}$ & $\begin{array}{c}\text { Di- } \\
\text { eldrin, } \\
\text { total }\end{array}$ & $\begin{array}{c}\text { Endo- } \\
\text { sulfan- } \\
\text { beta, } \\
\text { total }\end{array}$ & $\begin{array}{c}\text { Endo- } \\
\text { sulfan i, } \\
\text { Alpha, } \\
\text { water, } \\
\text { whole, } \\
\text { recov- } \\
\text { erable }\end{array}$ & $\begin{array}{c}\text { Endo- } \\
\text { sulfan, } \\
\text { sulfate, } \\
\text { total }\end{array}$ \\
\hline $06-05-92$ & $<0.03$ & $<0.10$ & $<0.1$ & $<0.10$ & $<0.09$ & $<0.020$ & $<0.04$ & $<0.10$ & $<0.60$ \\
$06-19-92$ & $<.03$ & $<.10$ & $<.1$ & $<.10$ & $<.09$ & $<.020$ & $<.04$ & $<.10$ & $<.60$ \\
$11-11-92$ & $<.03$ & $<.10$ & $<.1$ & $<.10$ & $<.09$ & $<.020$ & $<.04$ & $<.10$ & $<.60$ \\
\hline \hline
\end{tabular}

\begin{tabular}{|c|c|c|c|c|c|c|c|c|c|}
\hline Date & $\begin{array}{l}\text { Endrin, } \\
\text { alde- } \\
\text { hyde, } \\
\text { total }\end{array}$ & $\begin{array}{l}\text { EndrJn } \\
\text { water, } \\
\text { unflJ- } \\
\text { tered, } \\
\text { recov- } \\
\text { erable }\end{array}$ & $\begin{array}{c}\text { Gamma, } \\
\text { BHC, } \\
\text { Lindane, } \\
\text { total }\end{array}$ & $\begin{array}{l}\text { Heptz- } \\
\text { chlor, } \\
\text { lotal }\end{array}$ & $\begin{array}{l}\text { Hepta- } \\
\text { chior- } \\
\text { epoxide, } \\
\text { total }\end{array}$ & $\begin{array}{l}\text { Tox- } \\
\text { aphene, } \\
\text { total }\end{array}$ & $\begin{array}{l}\text { P,p' } \\
\text { DDD, } \\
\text { total }\end{array}$ & $\begin{array}{l}\text { p,p' } \\
\text { DDE, } \\
\text { total }\end{array}$ & $\begin{array}{l}\mathrm{p}, \mathrm{p}^{\prime} \\
\text { DDT, } \\
\text { total }\end{array}$ \\
\hline $06-05-92$ & $<0.20$ & $<0.06$ & $<0.03$ & $<0.03$ & $<0.80$ & $<2$ & $<0.10$ & $<0.04$ & $<0.10$ \\
\hline $06-19-92$ & $<.20$ & $<.06$ & $<.03$ & $<.03$ & $<.80$ & $<2$ & $<.10$ & $<.04$ & $<10$ \\
\hline $11-11-92$ & $<.20$ & $<.06$ & $<.03$ & $<.03$ & $<.80$ & $<2$ & $<.10$ & $<.04$ & $<10$ \\
\hline
\end{tabular}

66 Water Quallty of Siorm Runoff and Comparison of Procedures for Estimating Storm-Runoff Loads, Volume, EventMean Concentrationa, and the Mean Load for a Storm for Selected Properties and Constituents for Colorado Springs, Southeastern Colorado, 1992 
Table 21. Selected pesticide compounds for storm-runoff sites in Colorado Springs--Continued

\begin{tabular}{|c|c|c|c|c|c|c|c|c|c|c|}
\hline Date & Time & $\begin{array}{l}\text { Aldrin, } \\
\text { total }\end{array}$ & $\begin{array}{c}\text { BHC } \\
\text { Alpha, } \\
\text { total }\end{array}$ & \multicolumn{7}{|c|}{ Aroclor, PCB, total } \\
\hline \multicolumn{11}{|c|}{ 385118104485801 - Wahsutch Street at Cross Lane (Site 4) } \\
\hline $06-12-92$ & 1504 & $<0.040$ & $<0.03$ & $<0.1$ & $<1.0$ & $<0.1$ & $<0.1$ & $<0.1$ & $<0.1$ & $<0.1$ \\
\hline $07-25-92$ & 1408 & $<.040$ & $<.03$ & $<1$ & $<1.0$ & $<.1$ & $<.1$ & $<.1$ & $<.1$ & $<.1$ \\
\hline $11-21-92$ & 1005 & $<.040$ & $<.03$ & $<.1$ & $<1.0$ & $<.1$ & $<.1$ & $<.1$ & $<.1$ & $<.1$ \\
\hline
\end{tabular}

\begin{tabular}{|c|c|c|c|c|c|c|c|c|c|}
\hline Date & $\begin{array}{c}\text { Beta- } \\
\text { benzene, } \\
\text { hexa- } \\
\text { chloride, } \\
\text { total }\end{array}$ & $\begin{array}{c}\text { Chlor- } \\
\text { dane, cis, } \\
\text { water, } \\
\text { whole, } \\
\text { total }\end{array}$ & $\begin{array}{l}\text { Chtor- } \\
\text { dane, } \\
\text { total }\end{array}$ & $\begin{array}{c}\text { Chlor- } \\
\text { dane, } \\
\text { trans, } \\
\text { water, } \\
\text { whole, } \\
\text { total }\end{array}$ & $\begin{array}{c}\text { Delta, } \\
\text { benzene, } \\
\text { hexa- } \\
\text { chloride, } \\
\text { total }\end{array}$ & $\begin{array}{l}\text { Di- } \\
\text { eldrin, } \\
\text { total }\end{array}$ & $\begin{array}{l}\text { Endo- } \\
\text { sulfan- } \\
\text { beta, total }\end{array}$ & $\begin{array}{l}\text { Endo- } \\
\text { sulfan I, } \\
\text { Alpha, } \\
\text { water, } \\
\text { whole, } \\
\text { recov- } \\
\text { erable }\end{array}$ & $\begin{array}{c}\text { Endo- } \\
\text { sulfan, } \\
\text { sulfate, } \\
\text { total }\end{array}$ \\
\hline $06-12-92$ & $<0.03$ & $<0.10$ & 0.2 & $<0.10$ & $<0.09$ & $<0.02$ & $<0.04$ & $<0.10$ & $<0.60$ \\
\hline $11-21-92$ & $<.03$ & $<.10$ & $<. I$ & $<.10$ & $<.09$ & $<.02$ & $<.04$ & $<.10$ & $<.60$ \\
\hline
\end{tabular}

\begin{tabular}{|c|c|c|c|c|c|c|c|c|c|}
\hline Date & $\begin{array}{l}\text { Endrin, } \\
\text { alde- } \\
\text { hyde, } \\
\text { total }\end{array}$ & $\begin{array}{l}\text { Endrin } \\
\text { water, } \\
\text { unfil- } \\
\text { tered, } \\
\text { recov- } \\
\text { erable }\end{array}$ & $\begin{array}{l}\text { Gamma, } \\
\text { BHC, } \\
\text { Lindane, } \\
\text { total }\end{array}$ & $\begin{array}{l}\text { Hepta- } \\
\text { chlor, } \\
\text { total }\end{array}$ & $\begin{array}{l}\text { Hepta- } \\
\text { chlor- } \\
\text { epoxide, } \\
\text { total }\end{array}$ & $\begin{array}{c}\text { Tox- } \\
\text { aphene, } \\
\text { total }\end{array}$ & $\begin{array}{l}\text { P,P' } \\
\text { DDD, } \\
\text { total }\end{array}$ & $\begin{array}{l}\text { p,p' } \\
\text { DDE, } \\
\text { total }\end{array}$ & $\begin{array}{l}\text { p,p' } \\
\text { DDT, } \\
\text { total }\end{array}$ \\
\hline $06-12-92$ & $<0.20$ & $<0.06$ & $<0.03$ & $<0.03$ & $<0.80$ & $<2$ & $<0.10$ & $<0.04$ & $<0.10$ \\
\hline $07-25-92$ & $<.20$ & $<.06$ & $<.03$ & $<.03$ & $<.80$ & $<2$ & $<.10$ & $<.04$ & $<.10$ \\
\hline
\end{tabular}


Table 21. Selected pesticide compounds for storm-runoff sites in Colorado Springs--Continued

\begin{tabular}{|c|c|c|c|c|c|c|c|c|c|c|}
\hline \multirow{2}{*}{ Date } & \multirow{2}{*}{ Time } & \multirow{2}{*}{$\begin{array}{l}\text { Aldrin, } \\
\text { total }\end{array}$} & \multirow{2}{*}{$\begin{array}{c}\text { BHC } \\
\text { Alpha, } \\
\text { total }\end{array}$} & \multicolumn{7}{|c|}{ Arocior, PCB, total } \\
\hline & & & & 1016 & 1221 & 1232 & 1242 & 1248 & 1254 & 1260 \\
\hline \multicolumn{11}{|c|}{384935104501501 - Walmart at Eighth Street (Site 5) } \\
\hline $07-17-92$ & 0250 & $<0.04$ & $<0.03$ & $<0.1$ & $<1.0$ & $<0.1$ & $<0.1$ & $<0.1$ & $<0.1$ & $<0.1$ \\
\hline $08-03-92$ & 1717 & $<.04$ & $<.03$ & $<.1$ & $<1.0$ & $<.1$ & $<.1$ & $<.1$ & $<.1$ & $<1$ \\
\hline $12-06-92$ & 1115 & $<.04$ & $<.03$ & $<.1$ & $<1.0$ & $<.1$ & $<.1$ & $<.1$ & $<.1$ & $<.1$ \\
\hline
\end{tabular}

\begin{tabular}{|c|c|c|c|c|c|c|c|c|c|}
\hline Date & $\begin{array}{c}\text { Beta- } \\
\text { benzene, } \\
\text { hexa- } \\
\text { chlorlde, } \\
\text { total }\end{array}$ & $\begin{array}{c}\text { Chlor- } \\
\text { dane, cis, } \\
\text { water, } \\
\text { whole, } \\
\text { total }\end{array}$ & $\begin{array}{l}\text { Chior- } \\
\text { dane, } \\
\text { total }\end{array}$ & $\begin{array}{c}\text { Chlor- } \\
\text { dane, } \\
\text { trans, } \\
\text { water, } \\
\text { whole, } \\
\text { total }\end{array}$ & $\begin{array}{c}\text { Delta, } \\
\text { benzene, } \\
\text { hexa- } \\
\text { chlorlde, } \\
\text { total }\end{array}$ & $\begin{array}{l}\text { DI- } \\
\text { eldrin, } \\
\text { total }\end{array}$ & $\begin{array}{l}\text { Endo- } \\
\text { Sulfan- } \\
\text { beta, } \\
\text { total }\end{array}$ & $\begin{array}{l}\text { Endo- } \\
\text { aulfan I, } \\
\text { Alpha, } \\
\text { water, } \\
\text { whole, } \\
\text { recov- } \\
\text { erable }\end{array}$ & $\begin{array}{c}\text { Endo- } \\
\text { sulfan, } \\
\text { sulfate, } \\
\text { total }\end{array}$ \\
\hline $07-17-92$ & $<0.20$ & $<0.060$ & $<0.030$ & $<0.030$ & $<0.80$ & $<0.02$ & $<0.10$ & $<0.04$ & $<0.10$ \\
\hline 08-03-92 & $<.03$ & $<.10$ & $<.1$ & $<10$ & $<.09$ & $<.02$ & $<.04$ & $<.10$ & $<.60$ \\
\hline $12-06-92$ & $<.03$ & $<.10$ & $<.1$ & $<.10$ & $<.09$ & $<.02$ & $<.04$ & $<.10$ & $<.60$ \\
\hline Date & $\begin{array}{l}\text { Endrin, } \\
\text { alde. } \\
\text { hyde, } \\
\text { total }\end{array}$ & $\begin{array}{l}\text { Endrin } \\
\text { water, } \\
\text { unfil- } \\
\text { tered, } \\
\text { recov- } \\
\text { erable }\end{array}$ & $\begin{array}{c}\text { Gamma, } \\
\text { BHC, } \\
\text { Lindane, } \\
\text { total }\end{array}$ & $\begin{array}{l}\text { Hepts- } \\
\text { chlor, } \\
\text { total }\end{array}$ & $\begin{array}{l}\text { Hepta- } \\
\text { chlor- } \\
\text { epoxide, } \\
\text { total }\end{array}$ & $\begin{array}{l}\text { Tox- } \\
\text { aphene, } \\
\text { total }\end{array}$ & $\begin{array}{l}\mathbf{p}, \mathcal{p}^{\prime} \\
\text { DDD, } \\
\text { total }\end{array}$ & $\begin{array}{l}p, p^{\prime} \\
\text { DDE, } \\
\text { total }\end{array}$ & $\begin{array}{l}\text { P,P' } \\
\text { DDT, } \\
\text { total }\end{array}$ \\
\hline $07-17-92$ & $<0.20$ & $<0.06$ & $<0.03$ & $<0.03$ & $<0.80$ & $<2$ & $<0.10$ & $<0.04$ & $<0.10$ \\
\hline 08-03-92 & $<.20$ & $<.06$ & $<.03$ & $<.03$ & $<.80$ & $<2$ & $<.10$ & $<.04$ & $<.10$ \\
\hline $12-06-92$ & $<.20$ & $<.06$ & $<.03$ & $<.03$ & $<.80$ & $<2$ & $<.10$ & $<.04$ & $<.10$ \\
\hline
\end{tabular}

68 Water Quality of Storm Runoff and Comparison of Procedures for Estimating Storm-Runoff Loads, Volume, EventMean Concentrations, and the Mean Load for a Storm for Selected Properties and Constituents for Colorado Springs, Southeastern Colorado, 1992 